Portland State University

PDXScholar

\title{
Using Archaeological Fish Remains to Determine the Native Status of Anadromous Salmonids in the Upper Klamath Basin (Oregon, USA) Through mtDNA and Geochemical Analysis
}

Alexander E. Stevenson

Portland State University

Follow this and additional works at: https://pdxscholar.library.pdx.edu/open_access_etds

Part of the Animal Sciences Commons, and the Anthropology Commons Let us know how access to this document benefits you.

\section{Recommended Citation}

Stevenson, Alexander E., "Using Archaeological Fish Remains to Determine the Native Status of Anadromous Salmonids in the Upper Klamath Basin (Oregon, USA) Through mtDNA and Geochemical Analysis" (2011). Dissertations and Theses. Paper 444.

https://doi.org/10.15760/etd.444

This Thesis is brought to you for free and open access. It has been accepted for inclusion in Dissertations and Theses by an authorized administrator of PDXScholar. Please contact us if we can make this document more accessible: pdxscholar@pdx.edu. 
Using Archaeological Fish Remains to Determine the Native Status of Anadromous Salmonids in the Upper Klamath Basin (Oregon, USA) Through mtDNA and Geochemical Analysis

by

Alexander E. Stevenson

A thesis submitted in partial fulfillment of the requirements for the degree of

\author{
Master of Science \\ in \\ Anthropology
}

Thesis Committee:

Virginia L. Butler, Chair

Kenneth M. Ames

Douglas Deur

Portland State University

2011 


\begin{abstract}
Within the Upper Klamath Basin, Oregon, the native status of anadromous salmonids (Oncorhynchus spp.) has been a long standing question. Ongoing efforts to establish if these fish were native to the region prior to the construction of the Copco I Dam on the Klamath River (c.1917) have relied on sparse, contradictory and sometimes unreliable historic documentation and informant testimony. Current restoration projects with very high financial and social costs necessitate accurate and reliable data on salmonid species which once called the region home. Often, archaeolofaunal remains present a novel way to determine species present in an area prior to major habitat losses. This project analyzed fish remains from five previously excavated archaeological sites within the Upper Klamath Basin to determine which salmonid species were present prior to dam construction.
\end{abstract}

A total of 5,859 fish remains were identified to at least taxonomic order using morphological distinctions. Site collections were dominated by those of catostomids (suckers) and cyprinids (minnows). Archaeological deposits at these sites dated as far back as approximately 7,500 BP but were primarily from the last 2,000 years. Only eighty-one salmonid remains were observed within the sites included in this project. The low frequency of salmonid remains in these sites may be the result of cultural and/or natural processes such as density mediated attrition and archaeological sampling. Of these 81 specimens, 38 were subjected to mtDNA analysis for species identification. 
Seven specimens did not yield DNA sufficient for species identification, six specimens were identified as $O$. tshawytscha (Chinook) and the remaining 25 specimens were identified as $O$. mykiss (steelhead or redband trout). Geochemical analysis was used to determine the life history of the fish represented by the remains within these collections. Strontium Calcium (Sr:Ca) ratios were measured on twenty-eight specimens. Three specimens were determined to be from freshwater resident fish and 25 were determined to be from anadromous fish. The specimens which were genetically identified as $O$. tshawytscha were all determined to be anadromous. Of the 18 specimens which were identified as $O$. mykiss and were subjected to geochemical analysis two were from freshwater resident fish and sixteen were from anadromous fish. Four samples were not characterized genetically but were subjected to geochemical analysis; three of these were determined to be from anadromous fish and one from a freshwater resident fish. Thus, the remains of anadromous $O$. mykiss and $O$. tshawytscha were identified in archaeological deposits predating construction of the Copco I dam in the Upper Klamath Basin

While the genetic and geochemical analyses confirm the presence of skeletal remains from anadromous salmonids in the Upper Klamath Basin archaeological sites prior to dam construction these remains may, represent fish caught elsewhere and traded in. Two hypotheses address the introduction of these fish remains into pre-dam archaeological deposits, either they were traded/transported in from elsewhere (Trade/Transport Hypothesis) or they were caught locally (Local Catch Hypothesis). Expectations linked to each of these hypotheses were generated using ethnographic information from across the 
Pacific Northwest, including modern testimony from the Klamath Basin. Fish heads were often removed soon after capture in order to reduce spoilage of the rest of the fish. Thus, assemblages with many head parts are probably the result of local catch while those without head parts are probably the result of trade and/or transport. Two approaches were used to estimate the extent to which fish heads were deposited in sites. Basic proportions of cranial to post cranial remains from two sites provided a varied picture and did not readily support either the Local Catch or Trade/Transport hypotheses. Evaluation using scaled proportions based on frequency of skeletal elements within the body (Minimum Animal Units) show that four of the five assemblages were dominated by cranial remains and therefore suggest these fish were locally caught. Small samples sizes make it difficult to rigorously evaluate the hypotheses, though the dominance of cranial remains suggests salmonids were taken locally. Together these data indicate that anadromous $O$. tshawytscha and O. mykiss were taken from waters within the Upper Klamath Basin prior to the construction of Copco I. This study has provided accurate and reliable data, using a novel approach, on which restoration efforts in the region can rely for proper species reintroduction and habitat restoration efforts. 


\section{Acknowledgements}

This thesis has been a communal effort more than a project directed and performed solely by myself. In that vein I must thank Dr. Jessica Miller for her guidance in the more and less technical aspects of the geochemistry component of this effort. Drs. Dongya Yang and Camilla Speller deserve special credit for their quick turn around and fantastic job with the genetic analysis. Kelli Barnes and Dr. Nicole Misarti were helpful in getting samples prepared and providing technical expertise. Dr. Pam Endzweig at the Museum of Natural and Cultural History was always willing to let me access the collections used in this study and can't be thanked enough for her time and effort.

To my friends, thank you. Cassandra Manning and Tait Elder were always willing to put commas in my papers and forced me to reason through my occasional sweeping statements over the past couple of years. Anthony Hofkamp's energy and willingness to chat about salmon always kept me thinking about what more I could be doing. Danny Gilmour and Andrew Huff were a pleasure to spend time with in the lab despite the lack of windows they always provided cheer and an immense amount of help sorting through all those fish bones. Thankfully I have friends that had been down this path before; in particular Bob Kopperl and Ross Smith were always willing to talk about archaeology, fish, and trials and tribulations of grad school over a beer. 
Throughout my time at PSU, Dr. Kenneth Ames has been a continual source of good ideas, support and well pointed critique, thank you. I owe a debt of gratitude to Dr. Doug Deur for agreeing to sit on my thesis committee despite his busy schedule. The role of Dr. Virginia Butler in this project cannot be overstated. Certainly this project could not and would not have gotten started without her earlier pilot study and her passion for archaeology in general. Her knowledge, hard work and guiding hand have been an inspiration. Her generosity and goodwill provide a model to which I aspire.

I would like to thank my family. While my study may have seemed esoteric and perhaps unnecessary to them at times, they have been continually patient and supportive. Finally, Pamela has been a great supporter throughout my graduate school experience and especially during this project. Thank you for being there for me and for helping me to follow my passion.

Thank you to the many other individuals whom I haven't named that made this project possible. Of course, any errors, misjudgments, misinterpretations or other mistakes herein are completely my fault. 


\section{Table of Contents}

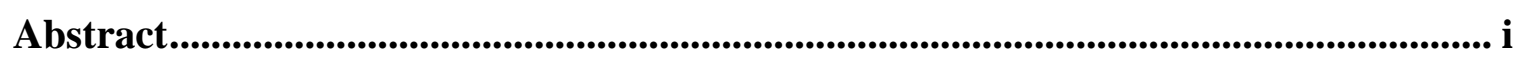

Acknowledgements .................................................................................................. iv

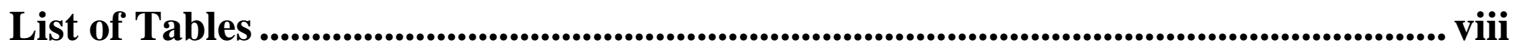

List of Figures.................................................................................................................................. ix

Chapter 1: Introduction ...................................................................................................1

Figure 1 Upper Klamath Basin towns, dams and archaeological sites ............................3

Chapter 2: Background ............................................................................................7

Klamath Basin human subsistence and settlement .............................................................. 9

Hydrologic modification and dam removal ..................................................................... 9

Evidence of anadromous salmonids in the Upper Klamath Basin............................................. 11

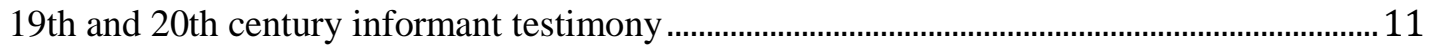

Previous ethnographic studies in the upper basin ..........................................................................14

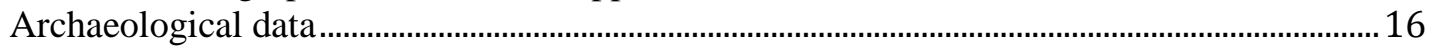

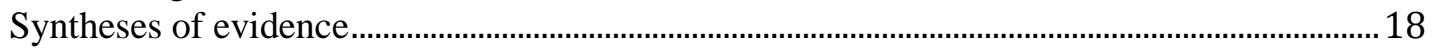

Specialized Analysis of Animal Remains ………………….......................................... 19

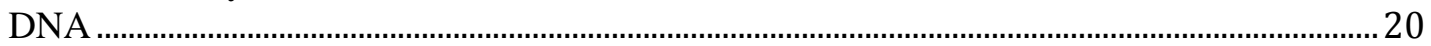

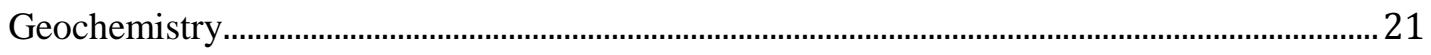

Chapter 3: Archaeological sites included in study .........................................................24

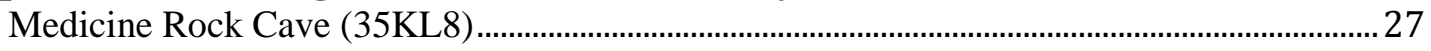

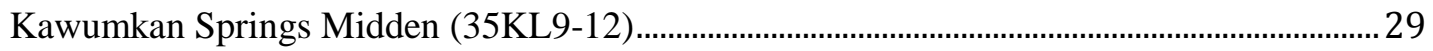

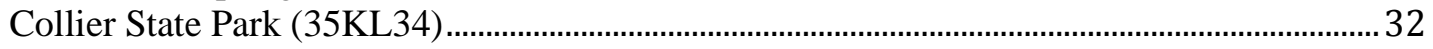

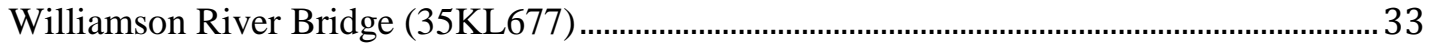

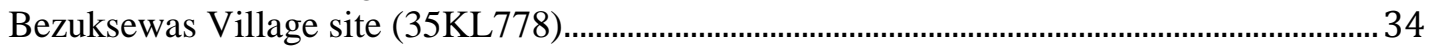

Chapter 4: Methods ....................................................................................................................36

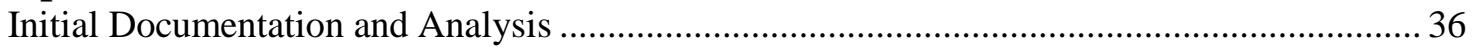

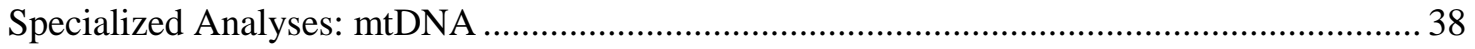

Specialized analyses: Geochemistry ....................................................................................... 39

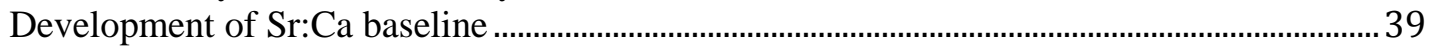

Sample Preparation........................................................................................................................... 42

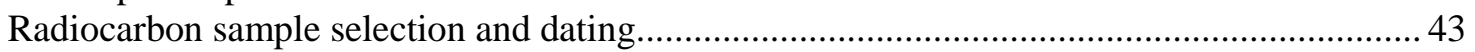

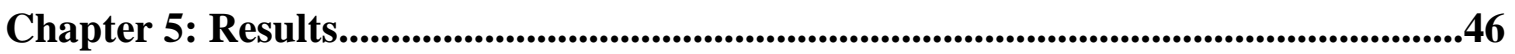

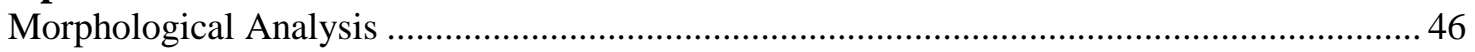

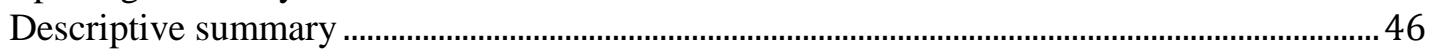

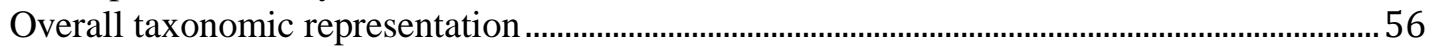

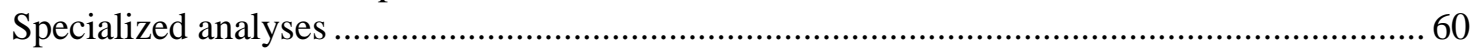

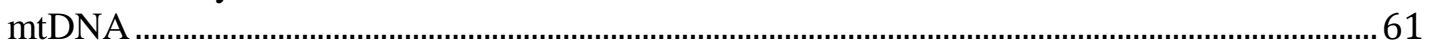


Geochemistry

Towards Sr:Ca validation

Chapter 6: Salmonids in the Upper Klamath Basin: Local Catch or Trade?.............74

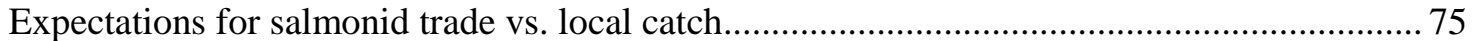

Evidence for Trade or Local Capture of Salmonids in Upper Klamath Assemblages .............. 82

Chapter 7: Conclusions ............................................................................................................88

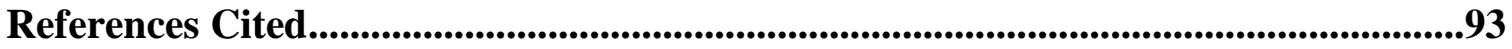

Appendix A: Archaeological Salmonid Remains Catalog........................................104

Appendix B: Simon Fraser University mtDNA Technical Report ..............................110

Appendix C: Radiocarbon Lab Data and Dates .............................................................126 


\section{List of Tables}

Table 1. Archaeological sites included in study .....................................................24

Table 2. Calibrated radiocarbon ages from archaeological sites

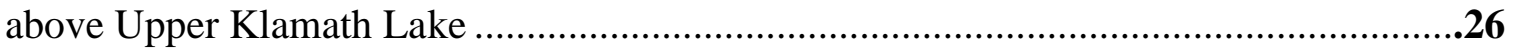

Table 3. Finest taxa frequency and \%NISP observed within each site

and time unit

Table 4. Frequency of salmonid specimens by archaeological site and time period, noting those submitted for specialized analysis ........................................60

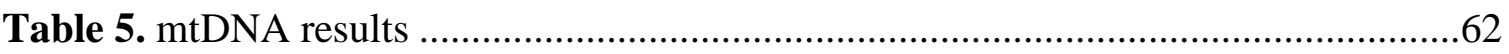

Table 6. Archaeological specimens submitted for DNA analysis and results .................64

Table 7. Sr:Ca ratios in Upper Klamath Basin waters ...............................................65

Table 8. Sr:Ca ratios for pairs of modern otolith/bone samples...................................67

Table 9. Sr:Ca values for archaeological specimens and assigned

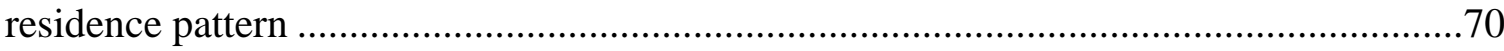

Table 10. Number of identified salmonid specimens to finest taxonomic

level as identified by mtDNA with geochemical results

Table 11. Minimum number of salmonid elements and \%MAU by site .83 


\section{List of Figures}

Figure 1. Upper Klamath Basin towns, dams and archaeological sites included in this study

Figure 2. Water sample locations in the Upper Klamath Basin.

Figure 3. Radiocarbon ages of time units at sites included in this study and time, units where salmonid remains were present

Table 4. Relationship between Sr:Ca in modern bone and otolith. .68

Table 5. Relationship between water and bone $\mathrm{Sr}: \mathrm{Ca}$

Figure 6. Predicted relationship between salinity and water Sr:Ca based on known values for Klamath River and marine

Figure 7. Precentage of cranial and postcranial remains from (A) standard salmonid skeleton using 1/8" mesh and (B) salmonid remains from Keatley Creek Housepit 7 .

Figure 8. Comparison of salmonid remains recovered using $1 / 8$ " mesh (A) complete salmonid skeleton; (B) Keatley Creek Housepit; (C) Bezuksewas Village (D) Williamson River Bridge.... 


\section{Chapter 1: Introduction}

Wildlife managers are asked to address and establish population baselines for management plans and restoration efforts. Often, these baselines are moving targets and are established using historic documentation and informant testimony, which, in the absence of physical specimens are not independently verifiable. Specimens which can provide accurate and precise taxonomic identifications are important for viable restoration and conservation to take place and archaeological data holds great potential to address many of these issues.

Archaeology has struggled to contribute to modern issues (Trigger 1989) but has recently contributed to wildlife management and conservation biology (Lyman 1996; Lauwerier and Plug 2004: Lyman and Cannon 2004; Lyman 2006). Zooarchaeological data have been used to highlight inconsistencies in historic observations (Butler and Delacorte 2004), assess human impacts on native faunal communities (Broughton 1994, 1997; Grayson 2001; Peacock et al. 2005), reconstruct past animal life histories and ranges (Etnier 2004; Whyte 2004; Robinson et al. 2009) and make accurate and precise species identifications (Speller et al. 2005; Cannon and Yang 2006). These issues are integral to properly implemented natural resource management plans and restoration efforts. This thesis contributes to the broader effort within zooarchaeology to contribute to wildlife management and conservation. Restoration and conservation issues are particularly important in the Klamath Basin (divided into upper and lower basins), located in southern 
Oregon and northern California (Figure 1). This area has been subjected to decades of major hydrologic modifications including the draining of wetlands and the construction of numerous dams for hydroelectric power (National Research Council [NRC] 2004). These landscape modifications have greatly impacted native wildlife communities, especially fish, three species of which are listed under the Endangered Species Act. Many believe that the placement of the first hydroelectric dam on the Klamath River, Copco I (which did not include a fish ladder), led to the extirpations of the anadromous salmonids from the Upper Klamath Basin. However the native status of these fish prior to Euroamerican contact in the area has been the subject of debate (e.g., Kroeber 1925:325; Hamilton et al. 2005).

In September of 2009, after years of negotiations and court proceedings, PacifiCorp and twenty-seven other parties reached an agreement to remove four dams along the Klamath River (NRC 2008; PacifiCorp 2009a). The Klamath Hydroelectric Settlement Agreement (KHSA) outlines the process prior to and including removal of the J.C. Boyle, Iron Gate, Copco 1 and Copco 2 Dams (PacifiCorp 2009b). This agreement balances the interests of many different entities with the explicitly stated goal of restoring anadromous salmonid runs to the Upper Klamath Basin. By March of 2012 the Secretary of the Interior must determine if dam removal will in reality balance these interests. 


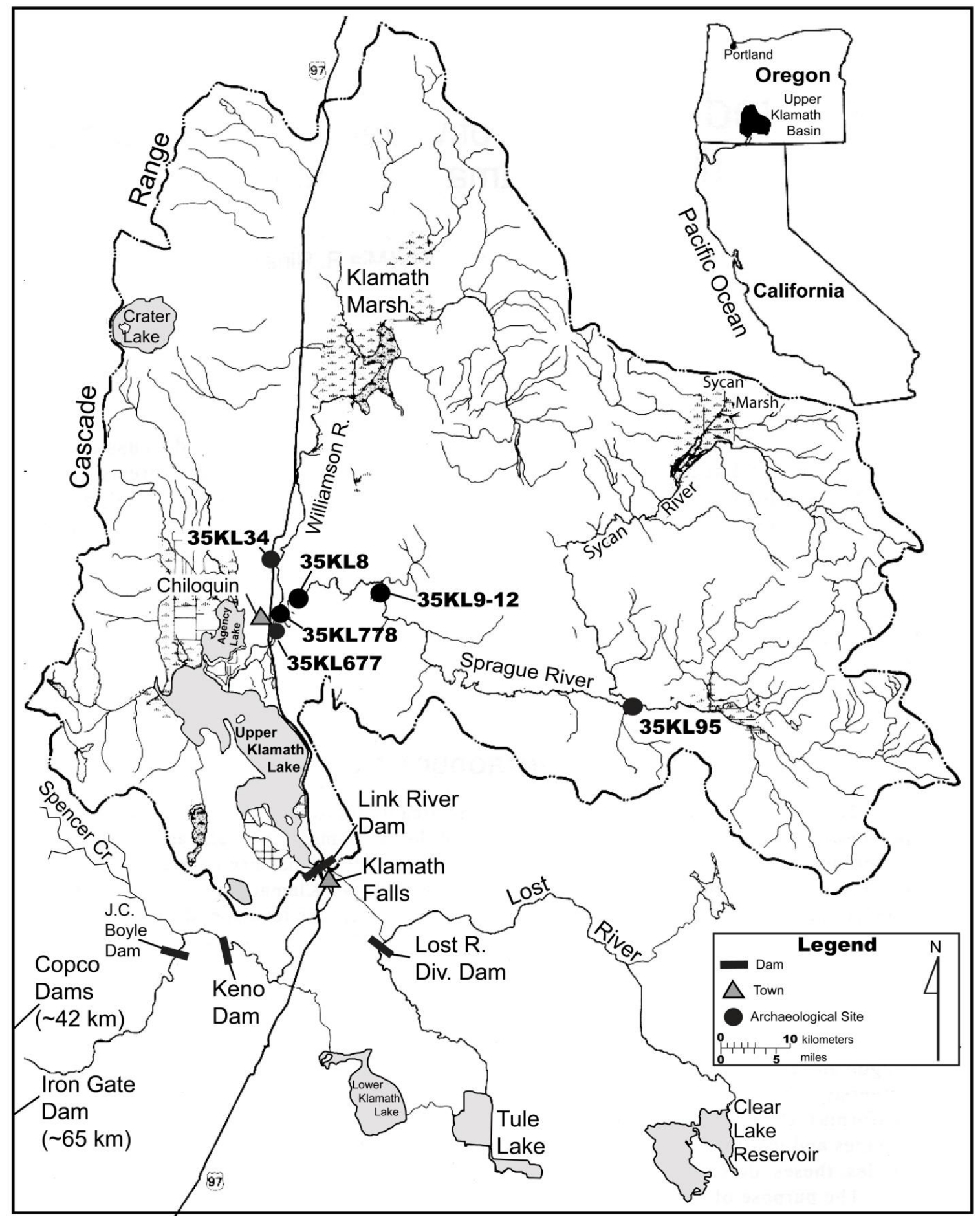

Figure 1 Upper Klamath Basin towns, dams and archaeological sites 
Numerous management-oriented studies have attempted to address the issue of native anadromous salmonids in the Upper Klamath Basin (Fortune et al. 1966; Lane and Lane 1981; Hamilton et al. 2005). These works have brought together multiple lines of evidence including: ethnographies (Gatschet 1890a, 1890b; Barrett 1910; Spier 1930), historic periodicals (e.g. Klamath Falls Evening Herald), biological studies (e.g., Snyder 1931; Chapman 1981; Huntington 2004) and even archaeological work (Cressman 1956). Together these sources provide a case for the historical presence of anadromous salmonids in the Klamath Basin. However, species identifications reported in historical and archaeological sources are ambiguous and occasionally contradictory. Accurate species identifications are necessary for proper restoration and management.

This study uses fish remains from five archaeological sites to determine the native status of anadromous salmonids in the Upper Klamath Basin. Analysis of over 15,000 fish specimens identified over 5,800 specimens to at least the family level. Of these, 81 were identified as salmonids based on skeletal morphology. Thirty-eight specimens were submitted for mitochondrial DNA (mtDNA) analysis in order to provide accurate and precise species identifications. Because Oncorhynchus mykiss has anadromous (steelhead) and freshwater (redband trout) forms that are indistinguishable genetically, this study employed geochemical analysis to characterize life history. Strontium-Calcium (Sr:Ca) ratios were measured in twenty-eight specimens because this technique has proven successful for identification of life history variability in many other studies (e.g. Zimmerman and Reeves 2002). 
While the identification of species and anadromy in these archaeological specimens is important, it does not directly address the native status of these fish. Salmonids may have arrived in the region as the result of trade. Recently, Deur (2003) reported testimony regarding the trade of salmon in the Upper Sprague River as well as Klamath Canyon. Trade of salmon into the Klamath Basin is documented elsewhere (e.g., Gatschet 1890:436). To address the possibility of introduction through trade I use ethnographic descriptions of fish trade and processing to develop expectations about the archaeological expression of locally caught versus trade-introduced fish. Differences in body part representation resulting from the removal of the head play a major role in distinguishing these two cultural mechanisms. The presence of salmonid cranial elements and the relatively low proportion of postcranial elements suggest that in fact these fish were taken locally and were not introduced into the Upper Klamath Basin through trade.

This thesis is organized into seven chapters. In Chapter 2, I present background information on the salmonids found in the Pacific Northwest as well as traditional lifeways of peoples in the Klamath Basin. I critically review the evidence that has been used to argue for salmonid presence in the Upper Klamath Basin up to this point including some critiques of the arguments. The genetic and geochemical methods employed in this study are also reviewed. Background information, including field methods and chronological control for each of the sites included in this study is discussed in Chapter 3. Chapter 4 reviews methods used in this study for faunal geochemical and mtDNA analysis. Results are discussed in Chapter 5. In Chapter 6, I evaluate two 
hypotheses to explain the presence of anadromous salmonids in archaeological sites in the Upper Klamath Basin. I examine the possibility that fish were either traded into the area or were caught locally. I use the ethnographic and archaeological records to develop expectations to distinguish these archaeologically. Finally, I present some conclusions and directions for future work in Chapter 7. 


\section{Chapter 2: Background}

There are seven species of Pacific salmon and trout (Oncorhynchus spp.) native to North America. These include: chum (O. keta), sockeye (O. nerka), Chinook (O. tshawytscha), coho (O. kisutch), pink (O. gorbuscha), steelhead (O. mykiss) and cutthroat (O. clarkii) (Groot and Margolis 1991; Quinn 2005). With rare exceptions, these species are anadromous and semelparous meaning they migrate from the ocean to freshwater, spawn and then die. Individuals emerge from eggs as fry and spend the first portion of their lives in freshwater. They then travel downstream and reach the ocean where they spend the majority of their lives, often one to four years. Typically, over $95 \%$ of their body mass is acquired while at sea. After spending time at sea, individuals return to their natal steams where they stop eating and invest all of their energy in migration and spawning. Most returning fish die; however approximately $20 \%$ of $O$. mykiss individuals are known to return to the ocean after spawning and go through the migration and spawning process again.

Salmon have been important to the people of the west coast of North America for millennia, especially in the Pacific Northwest (Cressman 1960; Schalk 1977; Fladmark 1975; Butler and Campbell 2004). Within the Klamath Basin, salmon is said to have been an important precontact subsistence resource (Lane and Lane 1981; Deur 2003), however, as noted above, the native status of anadromous species in the Upper Klamath Basin has been the subject of debate. Currently, runs of Chinook (O. tshawytscha) and 
coho (O. kisutch) migrate into rivers like the Salmon and Trinity in the Lower Klamath Basin (Moyle 2002). Coho in the lower basin are listed as threatened under the Endangered Species Act and comprise an evolutionary significant unit (ESU) (NRC 2004). Chinook runs in the lower basin are typically low in numbers but are persistent and are receiving increased attention because of tribal, public and private interest in preservation of the species in the area (e.g., King 2005).

Efforts to establish which anadromous salmon species, if any, migrated in to the Upper Klamath Basin have a long history dating back at least to the 1940's (Lane and Lane1981; United States vs. California Oregon Power Company [COPCO] 1942). Kroeber (1925:325) noted that "The salmon are said not to run into the Klamath Lakes." Gatschet's (1890) and Spier's (1930) informants said that salmon ran into the Upper Basin twice per year, directly contradicting Kroeber (1925). Court documents from the United States of American vs. COPCO (1942) provide informant testimony indicating that salmon did migrate beyond Upper Klamath Lake and that the construction of the Copco 1 Dam restricted these fishes' access to their natal streams. Investigators working primarily in the biological sciences have used multiple lines of evidence to make their case, including: stream flow modeling, known environmental tolerances, historical documentation and occasionally archaeology. This body of literature provides a strong case for native anadromous runs in the region. However, this case is not without issues, including uncritical use and misrepresentation of data. In this chapter I present evidence that bears directly on the native status of anadromous salmonids in the Upper Klamath 
Basin as well as issues with this evidence as it has been presented in the past. Because this basic situation is not unique to the Klamath salmon debate I also discuss literature regarding techniques used to grapple with the issue elsewhere in the world.

\section{Klamath Basin human subsistence and settlement}

According to late 19th and early 20th century ethnographic sources, native peoples in the Upper Klamath Basin focused largely on the exploitation of aquatic resources, primarily fish, geophytes (e.g. wocas [Nymphaea polysepala]), and freshwater mussels (e.g. Margaratifera falcata) (Gatschet 1890a; Barrett 1910; Spier 1930). Klamath peoples also relied on terrestrial game (e.g. deer [Odocoileus spp.]). Luther S. Cressman's (1956) archaeological investigations in the Upper Klamath Basin led him to conclude that this ethnographically observed wetland focus had great time depth. Philipek's (1982) study of settlement patterns in the region upheld Cressman's interpretation and showed that the vast majority of post-Mazama (c. 7,500 cal BP) archaeological sites in the region are in riverine and lacustrine settings.

\section{Hydrologic modification and dam removal}

Hydrologic modification and degradation of the Klamath Basin began in the mid-1800s and continued for decades (NRC 2004). Gold mining in the region choked streams with sediment and released untold amounts of mercury into aquatic systems. Settlers who 
followed these gold miners ran cattle and intensively farmed the Upper and Lower Klamath Basins. By the early 1900's the United States Bureau of Reclamation (USBR) began a campaign to drain Lower Klamath and Tule lakes to provide more arable land for farming, grazing and water for irrigation. The Klamath Project created by the United States Congress in 1905 provided additional government funding for landscape modifications which further diminished Klamath Basin wetlands (NRC 2004).

The construction of dams within the Upper Klamath Basin further altered the water regimes and is thought to have extirpated salmon runs in the region. Construction of the Copco I Dam began in 1911 and was completed in 1917 (NRC 2004) (Figure 1). The Copco I Dam did not include a fish ladder. Thus, it would have blocked fish migrating to the upper basin to spawn. After this first dam, five more dams were constructed along the main stem of the Klamath River within the upper basin.

Removal of the Klamath River dams and associated water rights issues have long been points of dispute among federal agencies, local governments and local residents in the region. After years of negotiations, efforts to remove the dams and restore salmon runs to the upper basin have made major headway. In September of 2009, after years of negotiations and court proceedings, PacifiCorp (the current owner/operator of the Klamath River dams) and twenty-seven other parties reached an agreement to remove four dams along the Klamath River (NRC 2008; PacifiCorp 2009a). The Klamath Hydroelectric Settlement Agreement (KHSA) outlines the process prior to and including 
removal of the J.C. Boyle, Iron Gate, Copco 1 and Copco 2 Dams (PacifiCorp 2009b). This agreement balances the interests of the public with the explicitly stated goal of restoring anadromous salmonid runs to the Upper Klamath Basin. By March of 2012 the Secretary of the Interior must determine if dam removal will balance these interests. While restoration of these runs is a major concern, no consensus exists regarding either the native status of anadromous salmonids in the region or, if they did exist historically, how far runs may have made it into the upper basin. Removal of the dams and associated restoration efforts are estimated to cost up to 4-billion dollars, which will be funded in part by California and Oregon taxpayers as well as federal monies. The high financial and social cost of this project necessitates great care in assessing the status and range of salmonids within the Klamath Basin.

\section{Evidence of anadromous salmonids in the Upper Klamath Basin}

Previous efforts to establish the native status of anadromous salmonids in the Upper Klamath Basin have relied on ethnographies, documentary evidence, and testimonies from area residents as part of fishing rights litigation and limited archaeological evidence.]

\section{9th and 20th century informant testimony}

Colloquial and ethnographic classification of animals has been shown to operate very 
differently than modern biological classification (Newmaster et al. 2006).

Ethnotaxonomies draw on different spheres of knowledge than Linnaean taxonomy. The two focus on different characteristics (e.g., gender, plumage, ripeness, etc.) for categorization. These incongruities between western scientific nomenclature and common names or ethnographic terminology may be difficult to resolve when applied to conservation and/or restoration projects.

Much historic and modern informant testimony (including ethnographies) has been used to argue that anadromous salmonids were in the Upper Klamath Basin prior to hydrodevelopment (Fortune et al. 1966; Lane and Lane 1981; Deur 2003; Hamilton et al. 2005). Interviews conducted with inhabitants of the region over the last 60 years attest to the value of salmonids in the area.

Lane and Lane (1981) document some of the strongest testimony regarding the native status of anadromous salmonids. The document draws testimony from briefs written during the initial phases of a native fishing rights court case brought by the United States Government against Copco (the former owner/operators of the dam) in the 1940s (also see US vs. COPCO 1942). Klamath tribal agent Courtright felt that the construction of Copco I and their deleterious effect on anadromous fish runs likely constituted a violation of United States and regional Native American treaties by the United States government. Both Native and Non-Native Americans who had lived in the Upper Klamath Basin for much or all of their lives provided testimony. Some non-residents also provided 
information for the case. In their testimony some individuals suggested anadromous salmon provided up to one-third of the tribe's food during the year. Most recorded testimony from the BIA case support the native status of anadromous salmonids in the upper basin.

Using documentary evidence for species identifications is difficult given varying approaches to classification, as discussed above. Common names which refer to species are fluid and may be linked to multiple species. Some species names provided by informants in the Lane and Lane (1981) document are in direct contradiction with the testimony of other individuals. The testimony of two informants illustrates the issues of ambiguity and contradiction, which exist in this document. John Cole, a Klamath tribal member, born in 1885, stated, "The fish I am speaking of were all King salmon. Some of the Indians called them dog salmon. I know the difference between a steelhead and a King salmon" (Lane and Lane 1981:58). Another tribal member, Dice Crane, born in 1882, "Assert[ed] that the salmon were 'dog salmon', not coho or Chinook" (Lane and Lane 1981:62). The common names used by these informants could refer to four different species (O. tshawytscha [Chinook or king], O. keta [dog or chum], O. kisutch [coho, silver], O. mykiss [steelhead, redband, rainbow]).

J.O. Snyder collected testimony regarding pre-dam construction anadromous salmonids in the Upper Basin (Snyder 1931). He encountered similar issues to those I highlighted in Lane and Lane (1981). He noted, "Testimony was conflicting and the lack of ability on 
the part of those offering information, to distinguish between even trout and salmon was so evident, that no satisfactory opinion could be formed as to whether king salmon [Chinook] ever entered Williamson River and the smaller tributaries of the lake. However this may be, large numbers of salmon annually passed the point where the Copco Dam is now located" (Snyder 1931:22).

\section{Previous ethnographic studies in the upper basin}

Ethnographers from academic and federal institutions spent time in the Upper Klamath Basin documenting the culture, language and material culture. Information from such ethnographic works provides useful information regarding anadromous salmonids in the upper basin.

Alfred Samuel Gatschet (1832-1907) was employed by the United States Geographical and Geological Survey to record the Klamath language during the late-nineteenth century. Gatschet's Ethnographic Sketch of the Klamath Indians of Southwestern Oregon attests to Klamath reliance on aquatic resources (Gatschet 1890a). His multi-volume Dictionary of the Klamath Language recorded thousands of Klamath words and their meanings (Gatschet 1890b). Of particular interest for this study, he recorded the Klamath word for salmon tchíalash...salmon; an important food-fish of the Máklaks Indians, ascending twice every year into the lakes and rivers of the Klamath Highlands, the first run being in June, the other in autumn: tsiäls-hä'mi "at salmon time"...tsials patsō'k "for 
feeding on salmon..."(Gatschet 1890:436). Additionally, Gatschet (1890:436) notes, "Salmon is the staple food of the Columbia River Indians, and is sold by them to the Máklaks [Klamath Indians]."

The Material Culture of the Klamath Lake and Modoc Indians of Northeastern California and Southern Oregon by Samuel A. Barrett (1910:250) describes special hooks used for salmon and further notes that "salmon and salmon trout were especially esteemed" (Barrett 1910:243). Barrett does not note what species of salmon were targeted with these special salmon hooks.

Leslie Spier (1893-1961) was a student of Franz Boas at Columbia and visited the Upper Klamath Basin for a month during 1925 and 1926 (Spier 1930). Although he visited the region after the completion of Copco I, his informants were generally middle-aged and elderly tribal members who knew the region before major Euro-American development took place. Spier mentions salmon in numerous contexts including mythology, subsistence and warfare. In Klamath Ethnography, Spier noted that his informant's testimony corroborated Gatschet's that salmon ran twice per year in June and autumn (Spier 1930:147) but that "comparatively few salmon are taken" (Spier 1930:231). Spier also notes a location, recorded by Gatschet (túpakshi or standing rock) on the Sprague River where he observed a dam for salmon (likely a rock weir) (Spier 1930:14). 
Other ethnographic works exist which cover the region (e.g., Kroeber 1925) but draw heavily on Gatschet (1890a, 1890b), Spier (1930) and Barrett (1910) for their information, especially concerning salmon. Stern (1965) in particular highlights Klamath lifeways after Euro-American settlement but relies on these works for early history in the area.

As part of the recent relicensing process associated with Klamath River dams, Deur (2003) has carried out additional ethnographic research which highlights the importance of salmonids to the Klamath peoples, echoing sentiments in Lane and Lane (1981). Deur did not attempt to determine salmonid species from the modern testimony of fish use. Part of Deur's study identified important salmonid fishing locations; the archaeological sites in this study are located in setting which correspond to the ethnographically documented fishing sites.

\section{Archaeological data}

Previous researchers interested in the native status of anadromous salmonids have cited archaeological evidence to support their case (Fortune et al. 1966; Chapman 1981; Lane and Lane 1981; Hamilton et al. 2005). These data are limited and their use by previous investigators is problematic, in particular, a brief review of fish remains from the region in Cressman (1956) is occasionally cited as evidence for salmon use in the region. 
From 1947 to 1951 Luther Cressman of the University of Oregon undertook a research program to resolve what he called "the Klamath problem" (Cressman 1956:375). His goal was to understand how the Klamath peoples were culturally related to tribes in the Great Basin. He excavated at least two archaeological sites, Kawumkan Springs Midden (35KL9-12) and Medicine Rock Cave (35KL8) which yielded many fish bones among other things.

Until my study, the fish remains from Cressman's work had never been systematically studied. Ichthyologist Dr. Carl Hubbs of Scripps Oceanographic Institute performed a cursory examination of these fish remains and in one instance concluded, "It is therefore highly probable that the vomer, a bone in the cranium of salmon, came from a King Salmon [Chinook]. Again, however, I would like to compare specimens before considering the decision at all final" (Cressman 1956:481). While the vomer is one cranial element that potentially allows for species identification (Gorschkov et al. 1979), Hubbs is clearly uncertain about the identification.

Multiple studies have cited Hubbs' analysis of Cressman's fish remains as evidence for anadromous salmonids in the Upper Klamath Basin. Fortune and colleagues (1966:5) reference the presence of fish bones "tentatively identified as Chinook" from Cressman's excavations. Lane and Lane (1981) quote Cressman's interpretation of subsistence at Kawumkan Springs Midden, where he notes "By level III the occupants were learning to exploit the runs of salmon from the sea..."(Cressman 1956:468). Hamilton and colleagues 
(2005) cite Cressman's data as evidence for Chinook salmon in the upper basin but do not also consider the tentative nature of Hubbs' species identifications.

\section{Syntheses of evidence}

Multiple researchers have synthesized the evidence for anadromous salmonids in the Upper Klamath Basin (Fortune et al. 1966; Lane and Lane 1981; Hamilton et al. 2005). Most recently Hamilton and colleagues (2005) reviewed the evidence for anadromous salmon and species biogeography in the region. They draw on the ethnographic sources discussed above as well as biological works (e.g. Snyder 1931) and local periodicals (e.g. Klamath Falls Evening Herald). Based on historical documentation, ethnographies, archaeological data and biological studies, they conclude that Chinook (O. tshawytscha) migrated into waters above Upper Klamath Lake but probably did not reach Klamath Marsh (Figure 1). Because of the similar environmental requirements of steelhead and Chinook, Hamilton et al. claim that steelhead would have inhabited the same geographic area as Chinook. They suggest that coho (O. kisutch) may have spawned in the Klamath River and its tributaries below Upper Klamath Lake (Figure 1). Further, they note that there may have been a small population of sockeye $(O . n e r k a)$ which spawned in the lake itself. Cutthroat (O. clarkii), chum $(O$. keta $)$, and pink (O. gorbuscha) salmon are thought to have not inhabited the upper basin. 
While they present a convincing body of evidence regarding the native status of anadromous salmonids in the region, Hamilton and colleagues' (2005) study provides a false sense of accuracy to their species and biogeographic determinations. Their review considers all mentions of "salmon" in the documentary record to refer to Chinook and provides no justification for this practice. The study does not draw on the full body of documentary evidence available. For example, they cite Evermann and Meek's (1897) study of Pacific Salmon distribution but do not include Gilbert's (1897) review of Klamath Basin fish. These two studies were published in the same volume of the Bulletin of the US Fish Commission. Hamilton and colleagues also rely on common species associations to suggest that steelhead would have been found in the Upper Klamath Basin because of they commonly co-occur with Chinook elsewhere.

Further, Deur (2003) notes that recent ethnographic testimony indicates that salmon may have occasionally ranged into Klamath Marsh and the Lost River (Figure 1). This contradicts the suggested upstream biogeographic distribution of Chinook in the paper by Hamilton et al. (2005) who derive their data from Spier (1930).

\section{Specialized Analysis of Animal Remains}

One way to resolve the question of what species were present in Upper Klamath Basin prior to dam construction is through genetic and geochemical analysis of fish remains from archaeological sites in the region. 


\section{DNA}

Research on ancient DNA from human and nonhuman animal bone has much expanded since its earliest use in the 1990s (Richards et al. 1993, 1995; Pääbo et al. 2004; Schurr 2004; Willerslev and Cooper 2005; Kitchen et al. 2008). Previous studies have demonstrated the feasibility of extracting ancient DNA from salmonid remains, allowing for species-level identifications (Butler and Bowers 1998; Yang et al. 2004; Speller et al. 2005). These studies have exclusively targeted short segments of mitochondrial DNA (mtDNA) because of their high copy number, many copies of the same gene or region, and the robust nature of short DNA segments. Yang et al. (2004) targeted both the cytochrome-B (cytB, 86 base pairs) and D-loop (174 base pairs) regions of mtDNA and amplified these regions using polymerase chain reaction (PCR). The examination of both the cytB and D-loop segments assured proper identification of and provided a crosscheck for contamination.

Within the Pacific Northwest, ancient salmonid mtDNA has been used to obtain species level identifications on skeletal elements up to 9,000 years old (Butler and Bowers 1998; Yang et al. 2004; Speller et al. 2005; Cannon and Yang 2006). Speller et al. (2005) tested the hypothesis that sockeye and Chinook salmon consumption was associated with high status individuals at the Keatley Creek site on the Canadian Plateau. Because sockeye have a high oil content they are commonly associated with high status in ethnographic accounts from the region. It would follow then, that, if this were the case prior to Euro- 
American contact, these fish would only be found in portions of houses associated with high status individuals. Speller and colleagues found that these fish were distributed evenly in space and were therefore probably not associated with solely high status individuals.

Recently, DNA from archaeological specimens has been incorporated into conservation and restoration projects. For example, Newsome et al. (2007) identified previously undocumented genetic diversity in precontact era northern fur seal (Callorhinus ursinus) populations along the Pacific coast of North America. Combined with geochemical analyses, Newsome et al. suggest that northern fur seal restoration efforts must be larger in geographic scope than was previously thought necessary to promote population growth and long-term health and survival of the species.

\section{Geochemistry}

Geochemistry is commonly used by fisheries managers and researchers to identify variation in life history (Kalish 1990; Campana 1999). Strontium-Calcium (Sr:Ca) ratios are particularly well suited for studies involving diadromous fishes because oceanic waters typically have a greater concentration of strontium than most freshwaters (Gunatilaka 1981). Furthermore, the Sr:Ca content in certain biogenic structures, such as otoliths and vertebrae, is positively related to water $\mathrm{Sr}: \mathrm{Ca}$. Although ambient water temperature and fish maturity have been shown to influence uptake in aragonitic (i.e. 
calcium carbonate) otoliths (Kalish 1989), Sr:Ca values can still be used to identify freshwater and marine residence (Kalish 1990; Zimmerman 2005; Zimmerman and Reeves 2000; Zimmerman et al. 2003). Zimmerman and Reeves (2002) used otolith Sr:Ca ratios to distinguish anadromous and resident $O$. mykiss progeny taken from the Deschutes River. Elevated Sr:Ca was noted in the core region of otoliths in progengy of anadromous females. This occurs because females initiate vitellogenesis during marine residency; hence, their eggs (and developing otoliths) contain marine-derived levels of Sr, which are greater than freshwater levels (Kalish 1990). Researchers have also employed geochemical methods to identify stocks (Campana et al. 2000) and natal sources (Ingram and Weber 1999). Gibson-Reinemer et al. (1999) found that Sr:Ca ratios and strontium isotopes $\left({ }^{87} \mathrm{Sr} /{ }^{86} \mathrm{Sr}\right)$ in otoliths could be used to provide information regarding hatchery of origin and individual movements of hatchery-reared O. mykiss. Allen et al. (2009) used Sr:Ca and Ba (Barium): Ca ratios to assess various aspects of green sturgeon (Acipenser medirostris) life history within the lower Klamath River; their analysis of elemental ratios in pectoral fin rays demonstrated marine residence in individuals between four to six years of age.

Recent research also has demonstrated the potential of using Sr:Ca ratios to identify life history characteristics of fish represented in archaeological deposits. Miller et al. (2011) used archaeological otoliths from the Upper Columbia River to examine life history variability of Chinook salmon (O. tshawytscha) over 250-500 years ago. They 
reconstructed adult body size and quantified $\mathrm{Sr}$ :Ca ratios along the otolith growth axis to estimate the size of juveniles when they entered estuary/marine waters. 


\section{Chapter 3: Archaeological sites included in study}

To determine which archaeological sites had been excavated above Upper Klamath Lake and which ones provided fish remains that could be included in this study, I examined records housed at the Oregon State Historic Preservation Office (Salem, OR). Five archaeological sites above the lake were noted to have fish remains: Medicine Rock Cave (35KL8), Kawumkan Springs Midden (35KL9-12), Collier State Park (35KL34), the Williamson River Bridge site (35KL677), and Bezuksewas Village (35KL778) (Figure 1;Table 1). All the sites are located within approximately $50 \mathrm{~m}$ of major rivers (Sprague, Williamson) and represent residential villages or fishing camps once occupied by Native Americans.

Table 1 Archaeological sites included in this study

\begin{tabular}{|c|c|c|c|c|c|}
\hline Site & Site Name & $\begin{array}{c}\text { Inferred Site } \\
\text { Type }\end{array}$ & $\begin{array}{c}\text { Excavated } \\
\text { Volume }\left(\mathbf{m}^{3}\right)\end{array}$ & Screen size & Citation \\
\hline $35 \mathrm{KL} 8$ & $\begin{array}{c}\text { Medicine Rock } \\
\text { Cave }\end{array}$ & $\begin{array}{l}\text { Fishing } \\
\text { location }\end{array}$ & unknown & $6.4 \mathrm{~mm}$ & Cressman 1956 \\
\hline 35KL9-12 & $\begin{array}{c}\text { Kawumkan } \\
\text { Springs } \\
\text { Midden }\end{array}$ & Residential & unknown & $6.4 \mathrm{~mm}$ & Cressman 1956 \\
\hline $35 \mathrm{KL} 34$ & $\begin{array}{l}\text { Collier State } \\
\text { Park }\end{array}$ & Residential & unknown & $6.4 \mathrm{~mm}$ & $\begin{array}{c}\text { Cheatham } \\
1990\end{array}$ \\
\hline 35KL677 & $\begin{array}{l}\text { Williamson } \\
\text { River Bridge }\end{array}$ & $\begin{array}{l}\text { Fishing } \\
\text { location }\end{array}$ & 43.7 & $3.2 \mathrm{~mm}$ & $\begin{array}{c}\text { Cheatham } \\
1991\end{array}$ \\
\hline $35 \mathrm{KL} 778$ & $\begin{array}{l}\text { Bezuksewas } \\
\text { Village }\end{array}$ & Residential & 124.7 & $3.2 \mathrm{~mm}$ & $\begin{array}{c}\text { Cheatham et al. } \\
1995\end{array}$ \\
\hline
\end{tabular}

Below, I present site summaries and review aspects of field methods, site function, and chronology that are important to interpreting the results from our analyses. Variation in excavation strategy, particularly mesh size used to screen matrix, affects the amount of 
bone recovered, specimen size and taxonomic abundance (e.g., Gordon 1993). Project sites were sampled using both $6.4 \mathrm{~mm}(1 / 4 ")$ and $3.2 \mathrm{~mm}\left(1 / \mathrm{s}^{\prime \prime}\right)$ mesh screens (Table 1) and thus some differences in fishbone recovery among sites could be due to field sampling. Fortunately, salmonid remains tend to be relatively large and even 1/4" mesh screens generally are adequate for recovering relatively complete salmonid remains (Butler 1993). Establishing site function, basically whether it represents a place of long-term residence or a specialized short-term fishing camp, is important for addressing questions about whether the fish were locally caught vs. obtained from trade.

Chronological control varied at each of the sites and this study needed to establish better temporal control for two reasons. First, this increased temporal control would allow identification and evaluation of temporal trends in salmonid distribution. Second, better understanding of the time depth at these sites would help provide a finer grained understanding of diagenesis which may influence elemental concentrations variably through time. Elemental diagenesis may skew or completely mask Sr:Ca ratios indicating freshwater residence or anadromy. The time periods used here vary from those used by the original investigators because new dates were acquired during this study. These newly acquired dates demonstrated a higher degree of stratigraphic mixing than was previously documented at the sites included in this study..

Previous researchers had obtained 23 radiocarbon dates and this study obtained 11 additional dates from project sites for this study (Table 2; Appendix 3). 
Table 2 Calibrated radiocarbon ages from archaeological sites above Upper Klamath Lake (bold indicates dates obtain as part of this project).

\begin{tabular}{|c|c|c|c|}
\hline Site & Description & Cal BP & Lab Code \\
\hline $35 \mathrm{KL} 9$ & Wood from house pit & $300-560$ & C-844 \\
\hline 35KL9-12 & $\begin{array}{l}\text { Level I }(0-40 \mathrm{~cm}) \text { terrestrial mammal } \\
\text { bone }\end{array}$ & $530-560$ & UCIAMS-87909 \\
\hline 35KL9-12 & $\begin{array}{l}\text { Level II }(40-80 \mathrm{~cm}) \text { terrestrial mammal } \\
\text { bone }\end{array}$ & $1220-1260$ & UCIAMS-84463 \\
\hline 35KL9-12 & $\begin{array}{l}\text { bone } \\
\text { Level III }(80-120 \mathrm{~cm}) \text { terrestrial mammal }\end{array}$ & 2930-3000 & UCIAMS-84462 \\
\hline 35KL9-12 & bone & $5060-5110$ & UCIAMS-84464 \\
\hline 35KL34 & Charred house timber & 270-320 & GaK-1659 \\
\hline 35KL34 & Charred bark on house timber & $360-430$ & GaK-1660 \\
\hline 35KL95 & Unknown material & $2040-2150$ & unknown \\
\hline 35KL95 & Unknown material & $2340-2370$ & unknown \\
\hline 35KL677 & $\mathrm{D} / \mathrm{D} / 6 / 2$ feature 2 charcoal & $30-140$ & Beta-26255 \\
\hline 35KL677 & E/D/8 terrestrial mammal bone & 150-170 & UCIAMS-84454 \\
\hline 35KL677 & O/A/4 terrestrial mammal bone & 830-870 & UCIAMS-84459 \\
\hline 35KL677 & M/A/7 terrestrial mammal bone & $910-930$ & UCIAMS-84458 \\
\hline 35KL677 & $\mathrm{L} / \mathrm{B} \& \mathrm{D} / 5 / 2$ charcoal & $910-1150$ & Beta-27451 \\
\hline 35KL677 & $\mathrm{M} / \mathrm{C} / 6 / 2$ charcoal & $910-1290$ & Beta-29044 \\
\hline 35KL677 & $\mathrm{J} / \mathrm{A} / 2$ terrestrial mammal bone & 1120-1170 & UCIAMS-84455 \\
\hline 35KL677 & $\mathrm{B} / \mathrm{C} \& \mathrm{D} / 10 / 2$ charcoal & $1180-1420$ & Beta-27449 \\
\hline 35KL677 & $\mathrm{M} / \mathrm{C} / 5 / 2$ feature 1 charcoal & $1410-1560$ & Beta-29043 \\
\hline 35KL677 & $\mathrm{M} / \mathrm{C} / 4 / 2$ feature 1 charcoal & $1530-1710$ & Beta-29041 \\
\hline 35KL677 & $\mathrm{M} / \mathrm{C} / 5$ terrestrial mammal bone & $1630-1670$ & UCIAMS-84457 \\
\hline 35KL677 & $\mathrm{O} / \mathrm{A} / 6 / 2$ charcoal & $1690-1840$ & Beta- 27452 \\
\hline 35KL677 & $\mathrm{J} / \mathrm{D} / 9$ terrestrial mammal bone & 2310-2330 & UCIAMS-84456 \\
\hline 35KL778 & 4W-5B-5 terrestrial mammal bone & 170-190 & UCIAMS-84461 \\
\hline 35KL778 & 4W-6B-6 terrestrial mammal bone & 170-190 & UCIAMS-84460 \\
\hline 35KL778 & 5E-3C-3 Feat10 charcoal & $140-220$ & Beta- 40178 \\
\hline $35 \mathrm{KL} 778$ & Test Pit B-5 charcoal & $140-220$ & Beta-32843 \\
\hline $35 \mathrm{KL} 778$ & 4W-6A-7 charcoal & $350-430$ & Beta-40176 \\
\hline 35KL778 & $4 \mathrm{~W}-5 \mathrm{~B}-4$ feature 4 charcoal & $360-430$ & Beta-39288 \\
\hline $35 \mathrm{KL} 778$ & 5E-1B-8 charcoal & $310-480$ & Beta-40177 \\
\hline 35KL778 & 4W-4D-3 Feat 1 charcoal & $430-520$ & Beta-40175 \\
\hline 35KL778 & 2E-1A-8 Feat 12 charcoal & $500-560$ & Beta-40174 \\
\hline 35KL778 & $5 \mathrm{~W}-1 \mathrm{C}-10$ charcoal & 680-800 & Beta-40179 \\
\hline $35 \mathrm{KL} 778$ & $5 \mathrm{~W}-3 \mathrm{~A}-5$ feature 13 charcoal & $1050-1170$ & Beta-39289 \\
\hline $35 \mathrm{KL} 778$ & 8W-6A-12 charcoal & $1060-1190$ & Beta-40180 \\
\hline 35KL778 & $8 \mathrm{~W}-1 \mathrm{~A}-10$ living floor charcoal & $1820-2000$ & Beta-32920 \\
\hline
\end{tabular}


Radiocarbon ages reported by previous investigators and those obtained as a part of this study were calibrated into calendar years using CALIB by Stuvier and Reimer (Copyright 1986-2010, M. Stuiver and P. J. Reimer, version 6.0.1). Therefore, all dates included are in calendar years before present (cal BP). For each radiocarbon sample I selected the age range at one standard deviation that had the highest probability of being correct. Calibrated dates were rounded to the nearest decade following Stuvier and Pollach (1977:362).

Use of some of the archaeological sites included in this study continued well into the historic era. Here the historic deposits are defined as those containing artifacts associated with Euroamerican contact in the historic period (e.g. glass, nails, ceramics). Following previous archaeological practice (Cheatham et al. 1995), I used the year 1860 as the beginning of the historic era, as this marks the establishment of Fort Klamath and time of sustained Euroamerican presence in the Upper Klamath Basin

\section{Medicine Rock Cave (35KL8)}

Medicine Rock Cave is located approximately $4.8 \mathrm{~km}$ (3 mi) east of Chiloquin along the Sprague River. Spier (1930:14), worked in the region in the early 1920's and noted the cave was the home of the Klamath culture hero, Kem $\breve{u}$ 'kumps and the site of the creation of the Klamath peoples. Wo'kstat, is located nearby and is the location of the Klamath "First Sucker Ceremony", an important Native American ritual celebrating the first 
sucker of the spring migration (Spier 1930:14 location 13). Luther Cressman from the University of Oregon and his crew excavated this site in the late 1940's using $40 \mathrm{~cm}$ levels, at times reaching depths of nearly $2 \mathrm{~m} ; 6.4 \mathrm{~mm}(1 / 4 ")$ mesh was used (Cressman 1956). Cressman suggested the site functioned as a fishing camp based on the high frequency of fish remains, apparent seasonal occupation and low frequency of mammal remains. Unfortunately, only 27 fish specimens were saved after excavation and available for our analysis.

Assigning an age to the Medicine Rock Cave deposits is difficult. The site was excavated before the development of radiocarbon dating and organics from the cave were not curated and therefore were unavailable for radiocarbon analysis. Cressman attributes a pumice layer in the cave to the eruption of Mt. Mazama, estimated to have occurred approximately 7,500 Cal BP (see Bacon 1983). Crater Lake, located 41 km (25 mi) northwest of the cave, is the remnant crater from this massive eruption. The attribution to Mt. Mazama was based on field study by Ira Allison, a prominent geologist at the time (Cressman 1956). Unfortunately, pumice samples were not retained from the work and so cannot be chemically studied to verify the source. Projectile point forms from the site can be linked with cultural historical time units spanning the past 7,500 years, but these age assignments are tenuous. Cressman did not record provenience information for the faunal materials from Medicine Rock Cave, thus the fish remains from that site included in this study cannot be assigned to any particular time period. 


\section{Kawumkan Springs Midden (35KL9-12)}

The Kawumkan Springs Midden site is located approximately $11 \mathrm{~km}$ (7 mi) east of Chiloquin along the Sprague River. Cressman and a University of Oregon team excavated the site as part of the same project that included Medicine Rock Cave (Cressman 1956). This site and the surrounding area has been identified as an ethnographically important salmon fishing location, as anadromous salmonids were said to spawn in springs like this along the Sprague River (Deur 2003). They excavated sediments in $2 \mathrm{~m}$ x $2 \mathrm{~m}$ units and used $6.4 \mathrm{~mm}(1 / 4 ")$ mesh screens. Artifacts and animal bones were collected in $40 \mathrm{~cm}$ thick levels to a depth below surface of $160 \mathrm{~cm}$ or greater (Cressman 1956). Four distinct locations spread over a $\sim 2 \mathrm{~km}$ stretch of the Sprague River (Cressman 1956: Map 3) were excavated and Cressman assigned each locale a unique site number $(35 \mathrm{KL} 9,10,11,12)$. However, Cressman's final report does not distinguish these locations. The provenience information associated with the fish remains we studied also treats the four sites as a single entity. Cressman suggested that the site was a residential village based on the presence of semi-subterranean housepits, which signified extended occupation. For his archaeological work at Kawumkan Springs Midden, Cressman drew heavily on Leslie Spier's ethnographic work, which noted, "Many people lived on both sides of the river there" (1930:14 location 14).

My initial search for the fish remains from this site at the $\mathrm{MNCH}$ in Eugene was not successful, but eventually bones from this site and Medicine Rock Cave were located at 
the University of Michigan Museum of Zoology and returned to Oregon for this study. The fish bone sample we examined (which includes those we could identify to some taxon and unidentifiable fragments) represents only about $10 \%$ of the total reported in Cressman (1956: Table 9; $\mathrm{n}=1493)$.

Prominent ichthyologist Dr. Carl Hubbs performed a cursory examination of a small sample of the fish remains from Kawumkan Springs Midden and excerpts from his letter report were included in Cressman (1956: Appendix D). With regards to salmonids, he notes the presence in Level III of the remains of a:

posterior tip of the maxillary of a salmonid, with rather large teeth. This is your specimen number 20-800. Level IV Lot number IV contains ... one maxillary and one vomer of the family Salmonidae. The mandible is number $20-820$ and the vomer is $20-624$. The two mandibles very likely represent trout. They seem to be more compressed, more delicate, and more curved than the maxillary on a King Salmon at hand that measures $376 \mathrm{~mm}$ in standard length. I will have to compare these jaw bones with specimens of several species, to feel at all sure. They are hardly of the size that would be expected of a mature salmon, though they might represent a grilse. The vomer, in contrast, is several times as heavy and coarse, particularly in the teeth, than in the $376 \mathrm{~mm}$ King Salmon at hand. From this I judge that the vomer came from a fish well over three feet in length, and likely about four or five feet long. It is therefore highly probable that the vomer came from a King Salmon. Again, however, I would like to compare specimens before considering the decision at all final (Cressman 1956:480).

This study, using DNA and geochemical analysis, reviews Hubbs' identifications, which have been widely cited in studies of pre-development salmonid distribution in the Upper Klamath Basin (e.g., Fortune et al. 1966; Lane and Lane 1981; Hamilton et al. 2005). 
Archaeological deposits at Kawumkan Springs Midden date between the historic era and approximately 5,000 BP. Three radiocarbon ages were obtained from terrestrial mammal bone, one from Level III and two from Level II (Table 2). The calibrated age for the sample in Level III suggests human use between 5,060 and 5,110 BP. Radiocarbon dates from Level II span the period between 1,220 and 3,000 BP (Table 2). A fourth radiocarbon age was obtained by Cressman (Libby 1954) from a housepit at 35KL9, spanning the period 300 and 560 BP. Faunal remains and other organics from Level I and IV either were not available for testing or, if submitted for study, contained insufficient collagen for dating. The $\sim 5000$ BP estimate for early occupation we obtained from Level III matches the age estimate obtained by obsidian hydration study of projectile points from the site (Aikens and Minor 1978).

Assigning fish remains from the various levels to specific time periods between $5000 \mathrm{BP}$ and the historic era is somewhat tenuous given stratigraphic mixing and the crude approach to record keeping from the 1950s. Some mixing (older items have moved higher, younger items have moved downward) is clearly shown by Aikens and Minor's work (1978). Yet the authors argue that despite some mixing, there is still some integrity to the site deposits, with younger temporally diagnostic projectile points tending to occur higher in site levels and older point forms tending to be in deeper levels (Aikens and Minor 1978). The authors note too, that other midden constituents conform to the stratigraphic sequence. For this study, fish remains recovered from Level III were assigned to the 5,060 and 5,110 BP period; fish remains from Level II were assigned to 
the 1,220 and 3,000 BP period. The age of specimens from Level I and Level IV is unknown.

\section{Collier State Park (35KL34)}

The Collier State Park site is located along the Williamson River approximately $13 \mathrm{~km}$ (8 mi) north of Chiloquin. In 1967 and 1968 David Cole of the University of Oregon led archaeological field school excavations of a single housepit at the state park (Cheatham 1990). The house pit was excavated in $2 \mathrm{~m}$ grid units, with $10 \mathrm{~cm}$ vertical levels to a maximum depth of $1.35 \mathrm{~m}$. During excavation, $6.4 \mathrm{~mm}(1 / 4 ")$ mesh was used except that the upper two excavation levels sediment were not screened or otherwise examined in the field, apparently because artifacts were not present. Cheatham suggests the housepit was occupied during the winter months, based on ethnographic records (e.g., Spier 1930), which document the use of these structures during the winter.

Two radiocarbon ages were obtained from timbers associated with the housepit (Table 2), suggesting construction and use between 270 and $430 \mathrm{BP}$. Temporally diagnostic projectile points from the site are generally consistent with this late period age assignment. Fish remains from this site are assigned only to this time period because the excavation appears to have only involved recovery of deposits associated with the pithouse. 


\section{Williamson River Bridge (35KL677)}

This site is located along the east and west side of Highway 97 in the vicinity of the bridge that crosses the Williamson River approximately $6 \mathrm{~km}$ (3.5 mi) south of Chiloquin. It was excavated in 1989 by the University of Oregon under the direction of Richard Cheatham in response to an Oregon Department of Transportation Project (ODOT) road project to mitigate site damage from road widening (Cheatham 1991). This archaeological site is undoubtedly contained within the Native American settlement that Spier (1930) noted in 1925-1926 extended nearly six miles along the Williamson River below its confluence with the Sprague. Ethnographically, the area surrounding and including this site is recognized as an important salmon fishing location (Deur 2003). During the 1989 excavation, $2 \mathrm{~m} \times 2 \mathrm{~m}$ units were excavated in $10 \mathrm{~cm}$ levels to a maximum depth of $1.4 \mathrm{~m}(4.6 \mathrm{ft}$.$) and sediments were screened through 3.2 \mathrm{~mm}(1 / 8 ")$ mesh. A total of $43.7 \mathrm{~m}^{3}$ of sediment was excavated. Given the great abundance of catostomid remains recovered, Cheatham suggested the site functioned mainly as fishing camp during the spring when suckers congregate to spawn. Spring occupation season was further indicated based on Chatters' analysis of the archaeological freshwater mussels (western pearlshell mussel, Margaratifera falcata) (Cheatham 1991: Appendix D). Specialized site function, as opposed to multi-season residence, was also indicated because of the low diversity of feature classes and tool forms. 
Two main time units were defined at the site: one ranging from $2400 \mathrm{BP}$ and the historic era; and a second, which dates between 830-1840 BP. While Cheatham (1991) suggested more fine grained temporal resolution than this, our review of the radiocarbon ages, including seven new dates acquired for this study, against strata and depth below surface suggested extensive mixing of deposits (Table 2).

\section{Bezuksewas Village site (35KL778)}

The excavated portions of the Bezuksewas Village site are located near the confluence of the Williamson and Sprague Rivers, along the east and west side of Highway 97 near present day Chiloquin, Oregon. Spier (1930:14) recorded the site during his work in the area and noted "there are many people in this town on the right bank which extends for a mile below the Sprague River mouth." Bezuksewas Village is located within what Deur (2003) has called the Chiloquin forks which, based on ethnographic testimony was a very important salmon fishing location. Richard Cheatham of the University of Oregon directed excavations at the site in 1990 (Cheatham et al. 1995). A total of $124.7 \mathrm{~m}^{3}$ of sediment was excavated using $2 \mathrm{~m}$ grid units and $10 \mathrm{~cm}$ vertical levels to a depth of 1.2 m; matrix was screened through $3.2 \mathrm{~mm}(1 / 8 ")$ mesh. Spier's (1930) description of the site as well as the presence of human remains, and a high diversity of tool forms and feature classes led Cheatham to infer the site functioned as a residential camp occupied throughout much of the year. 
Faunal remains at Bezuksewas Village were assigned to three time periods. The upper most deposit is associated with the historically-documented occupation, defined by the presence of historic artifacts (e.g. glass), and which date between the mid-nineteenth and the earliest $20^{\text {th }}$ century. The next time period $90-560 \mathrm{BP}$ was assigned based on radiocarbon dates obtained previously and two obtained for this study (Table 2). The oldest time period (680-2000 BP) was determined based on four previously obtained radiocarbon ages. 


\section{Chapter 4: Methods}

The faunal analysis portion of this project involved three steps. First, I documented all the fish remains from five archaeological sites in the Upper Klamath Basin. During this step, salmonid remains were identified and a subset was selected for additional specialized study. Second, I subjected specimens to geochemical analysis to determine elemental concentrations (Strontium and Calcium [Sr:Ca]) of archaeological salmonid bones. Third, mtDNA species identifications were performed.

\section{Initial Documentation and Analysis}

Faunal remains from the five sites were borrowed from the University of Oregon's Museum of Natural and Cultural History $(\mathrm{MNCH})$ in Eugene and transported to Portland State University's Zooarchaeology lab for detailed documentation between June and September, 2010. I performed analysis of the fish remains with two assistants (Andrew Huff and Daniel Gilmour). Specimen identifications were checked first by me and finally by Virginia Butler.

I examined all the fish remains from each site because sorting through each collection in its entirety was the only way to ensure that all the salmonid remains were identified. 
For each fish specimen, I recorded a standard set of information: provenience, mesh size, taxon, skeletal element, presence/absence of a unique landmark, whether the specimen was burned and other surface modifications such as digestive etching or possible butchering marks. Specimens were identified to the finest Linnaean taxonomic level possible, occasionally to species, but most commonly to the family level, using modern skeletons in Butler's lab and those borrowed from Oregon State University. Representative skeletons from all historically documented freshwater species (e.g., minnows and suckers), and anadromous species (salmonids) from Oregon were available for comparison. All records were entered into SPSS (Statistical Package for the Social Sciences) for further analysis. To compare and contrast faunal records within and between archaeological sites, specimens were tallied using the counting measure number of identified specimens (NISP) (Grayson 1984), which simply tallies all fragments or whole skeletal elements from a given taxon.

Salmonid specimens were further documented and studied given project goals, and because DNA and geochemical analyses would be destructive. Each salmonid specimen was assigned a unique alphanumeric catalog number which included a site abbreviation code (e.g. WRB from Williamson River Bridge site) and a sequential number within that site assemblage (e.g. WRB-1, WRB-2, etc.). The mass of each specimen was measured to the nearest $0.01 \mathrm{~g}$. Condition (e.g. good, degraded, poor, etc.) was noted as well as the side of the body each specimen came from. Multiple photographs were taken of each 
specimen. Photographs and specimen documentation was provided to $\mathrm{MNCH}$ upon completion of this project.

Samples were selected for specialized analysis using a nested strategy, which considered a number of factors. First, I prioritized collections by the amount of available contextual information from previous archaeological study. Second, within sites, samples were selected from a broad temporal range and from widely spaced excavation units and elevations, which reduced the likelihood of sampling the same individual fish multiple times. Third, preservation was evaluated and those in poor condition (e.g., burned, degraded) were excluded. The amount of tissue required for mtDNA ( $0.06 \mathrm{~g})$ and geochemical $(0.1 \mathrm{~g})$ analyses also constrained which bones were included. In many cases, an individual bone was not sufficiently large for both types of analyses to be run or even one kind of study. Finally, I used qualitative size comparisons to guide sample selection, drawing samples representing a range of fish body sizes, within the limits imposed by the analysis.

Samples larger than approximately $0.17 \mathrm{~g}$ were subdivided for both DNA and geochemical analysis. Bone fragments from specimens that were larger than the minimum size requirements were retained and returned to the $\mathrm{MNCH}$ for future study.

\section{Specialized Analyses: mtDNA}

All the genetic analysis, preparation, extraction, amplification and sequencing was 
performed by Dongya Yang and Camilla Speller at the ancient DNA laboratory in the Department of Archaeology at Simon Fraser University. Contamination controls included repeated extractions from individual samples, cross checks with different mtDNA regions and the physical separation of pre and post-amplification facilities and equipment. Yang and Speller's technical report is presented in Appendix 2.

\section{Specialized analyses: Geochemistry}

\section{Development of Sr:Ca baseline}

Previous research has shown interannual variations in concentrations of $\mathrm{Sr}$ and $\mathrm{Ca}$ in freshwaters, due to variation in precipitation and other factors. However, the ratio of $\mathrm{Sr}$ and $\mathrm{Ca}$ often covary and thus the $\mathrm{Sr}$ :Ca ratio can be relatively stable over time. In this case, I sought to characterize the relative difference between freshwaters in the Klamath River basin and examine the variation within the basin. To address this need, I collected thirteen, $50 \mathrm{ml}$ water samples from three locations on the eastern shore of Upper Klamath Lake; six individual locations along the Sprague and Williamson Rivers adjacent to each of the archaeological sites; and four additional locales (Wood and Link Rivers ,mainstem of the Klamath River below Keno, and Agency Lake) (Figure 2). Dr. Jessica Miller of Oregon State University processed the water samples. They were kept on ice, then filtered $(0.45 \mu \mathrm{m})$ and acidified within 48 hours of collection. Water $\mathrm{Sr}$ and $\mathrm{Ca}$ 
concentrations were measured with a Teledyne Leeman Prodigy inductively coupled

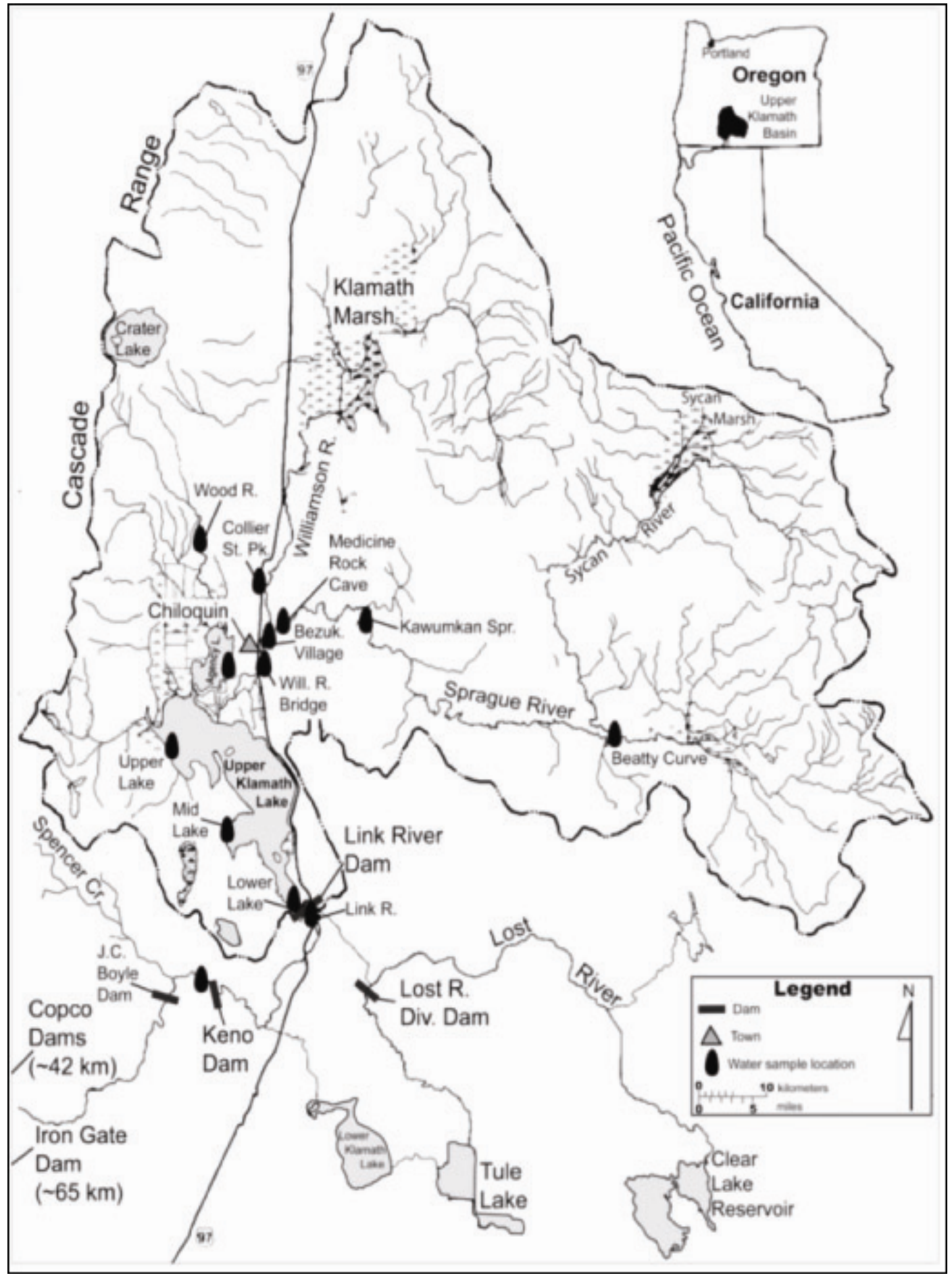

Figure 2 Water sample locations in the Upper Klamath Basin 
plasma-optical emission spectrometer (ICP-OES). Standard calibrations were generated with SPEX Certiprep® Group certified reference materials and samples of known concentration (National Institute of Standards and Technology, NIST 1643e) were introduced throughout the run to estimate accuracy: measured concentrations were within $4.6 \%$ and $1.0 \%$ for $\mathrm{Ca}$ and $\mathrm{Sr}$, respectively $(\mathrm{n}=3)$. Precision was estimated with repeated measurements of the same sample (NIST 1643e) and varied by $<5 \%$ for Ca and $<2 \%$ for $\operatorname{Sr}(n=3)$.

Available data on modern otolith $\mathrm{Sr}: \mathrm{Ca}$ in salmonids can be used to establish a threshold indicative of marine residence (Miller et al. 2010, Zimmerman 2005). However, less is known about the uptake of $\mathrm{Sr}$ in bone. Therefore, I examined bone from both anadromous and resident salmonids to empirically determine a value to discriminate marine from freshwater residency. Given limited access to previously collected data and time constraints, this study focused on two species, O. tshawytscha and O. mykiss; as these species were exclusively identified in the archaeological samples using mtDNA (see Results below), our model should be appropriate to Klamath Basin archaeological samples. Three data sets were used to establish the value for residency determination; (a) otoliths from modern Upper Klamath Basin redband trout (O. mykiss irideus; $\mathrm{n}=10$ ); (b) bone from modern redband trout from Upper Klamath Lake $(\mathrm{n}=1)$; and (c) otoliths and bone from modern Chinook salmon $(n=5)$. Samples were collected as follows: (a) Redband trout otoliths were collected in Kirk Springs and Spring Creek by the Oregon Department of Fisheries and Wildlife in 1990 and 1991; (b) Bone from one redband trout 
was collected by Bill Tinniswood of Oregon Department of Fish and Wildlife in October of 2009; (c) The five adult Chinook salmon that provided the paired bone/otoliths were collected from the Oregon ocean troll fishery in 2006.

\section{Sample Preparation}

Archaeological and modern bone samples were prepared following the same procedures. Bone specimens were embedded in 35-mm diameter plastic pucks with sample identification tags using Buehler Epo-Thin epoxy resin and placed in a desiccation chamber for 15 minutes to remove voids in the resin. Mounted samples were allowed to dry for 24 hours. The bottom of each puck was then removed using a low speed Buehler lapidary saw with a diamond blade. The exposed surface was then sanded using wet 600 2000 grit sand paper and $30 \mu \mathrm{m}$ lapping film. Pucks were cleaned ultrasonically with Nanopure ${ }^{\circledR}$ water for 25 minutes to remove residual sanding debris and then allowed to dry in a clean vent hood for 4 to 6 hours. This work primarily took place at Idaho State University at the Center for Archaeology, Materials and Applied Spectroscopy with the assistance of Kelli Barnes.

Sagittal sections of sagittal otoliths were prepared following standard protocols for elemental analysis (e.g. Miller 2009). Otoliths were mounted on glass slides using thermoplastic resin. Each side was ground using wet 800-2000 grit sandpaper and polished using 12-30 $\mu \mathrm{m}$ lapping film and alumina slurry. 
I measured $\mathrm{Sr}$ and $\mathrm{Ca}$ in otolith and bone samples using LA-ICP-MS at the W. M. Keck Collaboratory for Plasma Spectrometry at Oregon State University (10/27/10 and 10/28/10). Jessica Miller and Andy Ungerer guided my work with the instruments as well as data analysis. LA-ICP-MS was performed using a New Wave DUV193nm excimer laser with a VG PQ ExCell ICPMS (Thermo Scientific). Samples were pre-ablated to remove any surface contamination using a laser spot size of $80 \mu \mathrm{m}, 1 \mathrm{~Hz}$ pulse rate, and $80 \mu \mathrm{m} / \mathrm{sec}$ scan speed. Sample ablation employed a $40-\mu \mathrm{m}$ spot size, $8 \mathrm{~Hz}$ pulse rate and $10 \mu \mathrm{m} / \mathrm{sec}$ scan speed. Data were collected from two to four locations per sample (transect length ranged from 500-1500 $\mu \mathrm{m}$ ) and averaged for each sample. Mean ion ratios were calculated across a $150-\mu \mathrm{m}$ portion of each transect. Sr:Ca ratios were converted to molar ratios based on measurements of known elemental concentrations within NIST 612 glass standards. Limits of detection were calculated as three standard deviations above background measurements ( 0.10 for $\mathrm{Ca}$ and $\mathrm{Sr})$. The mean relative standard deviations were $3.3 \%$ for $\mathrm{Ca}$ and $6.6 \%$ for Sr. A calcium carbonate standard prepared by the United States Geological Society (USGS MACS-1) provided an external estimate of accuracy (99\% for $\mathrm{Sr} / \mathrm{Ca})$.

\section{Radiocarbon sample selection and dating}

Specific reasoning for radiocarbon sample selection at each site varied because of unique issues associated with the method of excavation and amount of stratigraphic mixing at 
each site (Table 2; Appendix 3). However, in general, radiocarbon samples were selected that were physically as close as possible to salmonid remains.

A total of 13 terrestrial mammal bone specimens were selected from project sites for accelerator mass spectrometry (AMS) analysis (Appendix 3). Recent advances in radiocarbon dating have allowed increases in both the precision and accuracy of age estimates. New techniques reduce contamination and remove all but the original organics from the selected sample. Because of these increased contamination controls, large sample sizes (1-2 g) are required prior to processing. Fish remains are often too small to study using these techniques. Dating salmonid remains from these sites would be ideal to get the most accurate date for the fish however multiple issues, including: the marine reservoir effect, insufficient tissue from skeletal elements and a limited number of samples prevented the use of these bones for dating. Traditional materials used for radiocarbon dating (e.g. wood and charcoal) were not available from the excavated sites included in this study or were from unknown provenience within sites. The remains of terrestrial mammals were selected for dating because they met necessary sample mass requirements and additionally are more likely to be directly associated with past human activity than charcoal or wood. Two samples from Kawumkan Springs Midden level I did not provide enough collagen for dating after pretreatment. Samples were not selected from $35 \mathrm{KL} 8$ or $35 \mathrm{KL} 34$ because suitable materials were not available. 
Radiocarbon samples were prepared and pretreated using ultra-filtration (Kennett et al. in press) at the University of Oregon Archaeometry laboratory by Brendan Culleton, under the direction of Dr. Douglas Kennett. $\mathrm{CO}_{2}$ samples were submitted to the Keck Carbon Cycle Mass Spectrometer at the University of California, Irvine. 


\section{Chapter 5: Results}

The results for this study are reported in three parts, which follow the three phases of laboratory analysis performed during the course of this project.

\section{Morphological Analysis}

Over 15,000 fish bones and teeth were documented in the archaeological site collections; 5,859 of these could be identified to some taxonomic level (Table 3).

\section{Descriptive summary}

Table 3 presents the frequency (NISP) of icthyofauna recovered from each of the five sites included in this study. Here, I describe criteria used to identify specimens from each taxon and present element frequencies using the tallying method NISP. Species

identifications made through genetic analysis of salmonid specimens are also included (see below for further discussion of results of genetic analysis). 


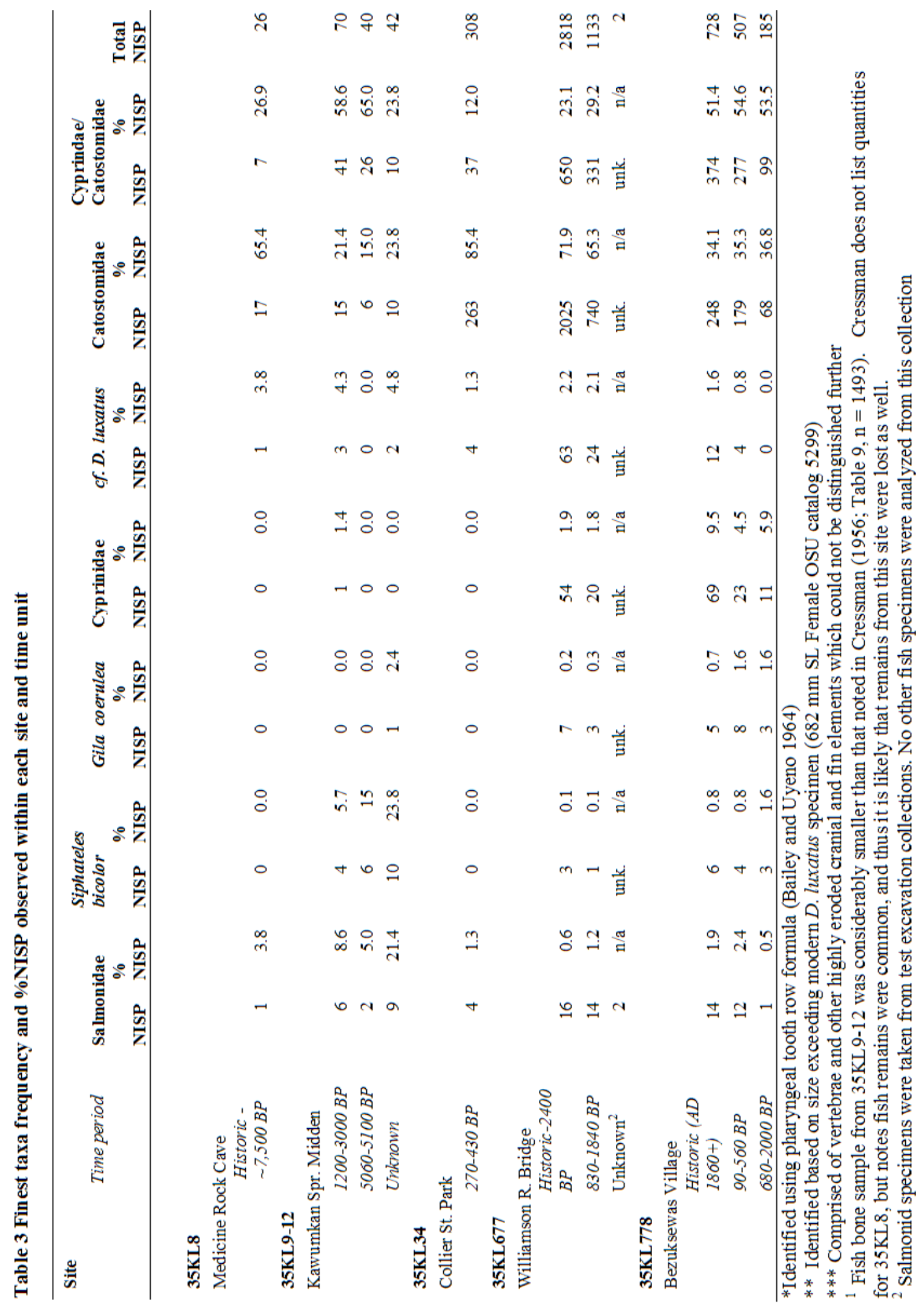


Class: Osteicthyes - Bony Fishes

Order: Salmoniformes

Family: Salmonidae - Salmons, Trouts, Whitefish

35KL8 1 type II vertebra

35KL9-12 1 indeterminate vertebra, 4 type II vertebrae, 3 type III vertebrae: 8 specimens

35KL34 1 opercle, 2 prootics, 1 pterotic: 4 specimens

35KL677 1 articular, 1 ceratohyal, 1 dentary, 1 coracoid, 3 indeterminate vertebrae, 6 type II vertebrae, 3 type III vertebrae, 1 type IV vertebra: 17 specimens

35KL778 1 supracleithrum, 1 indeterminate vertebra, 1 vertebra fragment, 14 type II vertebrae, 2 type III vertebrae: 19 specimens

Oncorhynchus tshawytscha - Chinook salmon

35KL9-12 1 type II vertebra, 1 type III vertebra: 2 specimens

35KL677 1 type II vertebra, 1 type III vertebra: 2 specimens

35KL778 1 type II vertebra, 1 vertebra fragment: 2 specimens 
Oncorhynchus mykiss - steelhead, redband trout

35KL9-12 2 maxillae, 1 vomer, 7 type II vertebrae 4 type III vertebrae: 14 specimens

35KL677 2 dentaries, 1 ceratohyal, 1 ectopterygoid, 1 hyomandibula, 6 type II vertebrae, 1 type III vertebrae: 12 specimens

35KL778 1 hypohyal, 1 cleithrum, 1 urohyal, 3 type III vertebrae: 6 specimens

Remarks: Seven species of Pacific salmon (Oncorhynchus spp.) are found along the west coast of North America (Quinn 2005). Except for O. mykiss, which includes marine and freshwater populations, these fish are strictly anadromous. These species are readily identifiable in life based on soft tissue morphology but are difficult to distinguish through skeletal morphology.

Archaeological specimens were identified to taxonomic family using comparative specimens from Virginia Butler's collection. Skeletons from all seven species were available for comparison. Vertebrae types were identified using criteria established by Butler (1990).

One vomer (KSM-8) from Kawumkan Springs Midden was examined by Dr. Carl Hubbs in 1950 (Cressman 1956). He tentatively identified this specimen as Chinook based on its large size, however genetic analysis undertaken here has identified it as a vomer from $O$. 
mykiss. Hubbs noted that this vomer was likely from a fish of at least three but perhaps four or five feet in length, making this a particularly large individual, perhaps on the scale of those represented by KSM-2 and MRS-1.

Four of the type II and four type III vertebrae were articulated and comprise a single specimen, KSM-4. This specimen appeared fresh and appeared to have undergone very little post-depositional modification. This is surprising given its recovery from level II of the excavation and associated dates of 1220-3000 Cal BP.

Resident $O$. mykiss (redband trout) currently inhabits the Upper Klamath Basin but no anadromous forms are found in the region. Chinook and steelhead (anadromous $O$. mykiss) are known within the Lower Klamath Basin and figure heavily in informant accounts of pre-development salmonids in the upper basin (Lane and Lane 1981; Deur 2003; Hamilton et al. 2005) although these historic identifications may be problematic.

\section{Order: Cypriniformes}

Family: Cyprinidae/Catostomidae - Minnows and Suckers

35KL8 1 ultimate vertebra, 3 abdominal vertebrae, 3 caudal vertebrae: 7 specimens

35KL9-12 1 indeterminate vertebra, 8 vertebra fragments, 3 ultimate vertebrae, 25 abdominal vertebrae, 40 caudal vertebrae: 77 specimens 
35KL34 1 indeterminate vertebra, 1 vertebra fragment, 24 abdominal vertebrae, 11 caudal vertebrae: 37 specimens

35KL677 105 indeterminate vertebrae, 143 vertebrae fragments, $11^{\text {st }}$ or $2^{\text {nd }}$ vertebra, 23 ultimate vertebrae, 364 abdominal vertebrae, 345 caudal vertebrae: 981 specimens

35KL778 138 indeterminate vertebrae, 176 vertebrae fragments, 12 ultimate vertebrae, 230 abdominal vertebrae, 194 caudal vertebrae: 750 specimens

\author{
Family: Catostomidae - Suckers
}

35KL8 2 ceratohyals, 5 hyomandibulas, 1 interopercle, 2 opercles, 1 parasphenoid, 1 subopercle, 1 urohyal, 1 vomer, 2 weberian processes, 1 pharyngeal: 17 specimens

35KL9-12 7 basioccipitals, 1 opercle, 2 palatines, 3 pterotics, 1 weberian process, 10 main pharyngeals, $11^{\text {st }}$ vertebra, $62^{\text {nd }}$ vertebrae: 31 specimens

35KL34 3 angulars, 3 basiocciptials, 8 ceratohyals, 24 dentaries, 1 epihyal, 2 epiotics, 12 exoccipitals, 14 frontals, 16 hyomandibulas, 22 interopercles, 5 maxillae, 17 mesopterygoids, 10 metapterygoids, 18 opercles, 2 palatines, 16 parasphenoids, 7 prefrontals, 7 preopercles, 8 prootics, 13 pterotics, 4 quadrates, 20 subopercles, 8 
sphenotics, 2 subopercles, 4 urohyals, 6 vomers, 1 cleithrum, 1 basipterygium, 3 supratemporals, 2 pharyngeals, 3 parietals, $12^{\text {nd }}$ vertebra: 263 specimens

35KL677 141 angulars, 103 basioccipitals, 277 ceratohyals, 202 dentaries, 85 epihyals, 11 epiotics, 31 exoccipitals, 41 frontals, 162 hyomandibulas, 13 hypohyals, 38 interopercles, 182 maxillae, 96 mesopterygoids, 60 metapterygoids, 72 opercles, 105 palatines, 159 parasphenoids, 3 prefrontals, 71 premaxillae, 43 preopercles, 20 prootics, 2 ptersphenoid, 38 pterotics, 115 quadrates, 16 sphenotics, 66 subopercles, 20 supraethmoids, 15 supraoccipitals, 40 urohyals, 40 vomers, 69 cleithra, 31 coracoids, 65 postcleithra, 3 posttemporals, 26 scapulas, 5 supracleithra, 49 basipterygia, 57 weberian processes, 11 main pharyngeals, 41 parietals, 37 dorsal expanded processes, $461^{\text {st }}$ vertebrae, $582^{\text {nd }}$ vertebrae: 2765 specimens

35KL778 15 angulars, 26 basioccipitals, 42 ceratohyals, 27 dentaries, 8 epihyals, 6 epiotics, 11 exoccipitals, 15 frontals, 24 hyomandibulas, 3 hypohyals, 12 interopercles, 11 maxillae, 18 mesopterygoids, 19 metapterygoids, 16 opercles, 18 palatines, 24 parasphenoids, 1 prefrontals, 4 premaxillae, 7 preopercles, 2 prootics, 2 pterotics, 15 quadrates, 3 sphenotics, 6 subopercles, 3 supraethmoids, 7 supraoccipitals, 4 urohyals, 11 vomers, 14 cleithra, 3 coracoids, 14 postcleithra, 4 scapulas, 5 supracleithra, 13 basipterygia, 12 weberian processes, 5 pharyngeals, 14 parietals, 5 dorsal expanded processes, $241^{\text {st }}$ vertebrae, $232^{\text {nd }}$ vertebrae: 495 specimens 


\section{cf. Deltistes luxatus - Lost River Sucker}

35KL8 1 metapterygoid

35KL9-12 1 basioccipital, 1 opercle, 1 pterotic, 2 abdominal vertebrae: 5 specimens

35KL34 1 frontal, 2 parasphenoids, 1 sphenotic: 4 specimens

35KL677 5 angulars, 3 basioccipitals, 5 ceratohyals, 14 dentaries, 2 epihyals, 1 frontal, 8 hyomandibulas, 12 maxillae, 2 mesopterygoids, 4 metapterygoids, 4 opercles, 3 palatines, 2 parasphenoids, 2 premaxillae, 1 pterotic, 3 quadrates, 1 subopercle, 2 supraethmoids, 4 vomers, 3 cleithra, 1 coracoid, 1 scapula, 2 basipterygium, 2 abdominal vertebrae: 87 specimens

35KL778 2 angulars, 1 exoccipital, 1 hyomandibular, 2 maxillae, 2 mesopterygoids, 1 metapterygoid, 1 opercle, 1 preopercle, 1 quadrate, 1 post-cleithrum, 1 basipterygium, 1 parietal: 16 specimens

Family: Cyprinidae - Minnows

35KL9-12 1 pharyngeal 
35KL677 2 basioccipitals, 2 ceratohyals, 2 dentaries, 2 frontals, 4 hyomandibulas, 2 maxillae, 1 mesopterygoid, 1 metapterygoid, 15 opercles, 1 palatine, 5 preopercles, 3 quadrates, 1 subopercle, 3 urohyals, 22 cleithra, 8 pharyngeals: 74 specimens

35KL778 7 basioccipitals, 1 ceratohyal, 2 frontals, 11 hyomandibulas, 1 maxilla, 18 opercles, 1 parasphenoid, 1 preopercle, 2 quadrates, 4 urohyals, 33 cleithra, 20 pharyngeals, $22^{\text {nd }}$ vertebrae: 103 specimens

Gila coerulea - Blue chub

35KL9-12 1 pharyngeal

35KL677 4 pharyngeals

35KL778 16 pharyngeals

Siphateles bicolor - Tui chub

35KL9-12 20 pharyngeals

35KL677 10 pharyngeals 
35KL778 13 pharyngeals

Remarks: Four species of catostomid (Catostomus snyderii, C. rimiculus, Chasmistes brevirostris, Deltistes luxatus) are native to the Upper Klamath Basin and inhabit both the rivers and lakes within the region (Moyle 2002). These species possess no distinctive skeletal characters that allowed for differentiation during morphological analysis. In a previous portion of this project attempts were made to distinguish species using qualitative characteristics on jaw elements. Unfortunately these attempts were not successful. Investigators have noted a high degree of genetic similarity and hybridization among the various species of sucker (NRC 2004:242-244). Specimens assigned to $c f . D$. luxatus were distinguished because of exceptional size. The Lost River Sucker is known to reach one meter in length, which is much larger than the other three species of Catostomid in the Klamath system (Moyle 2002). I used a reference specimen, which measured $682 \mathrm{~mm}$ standard length (OSU catalog number 5299) to assign archaeological specimens to this species. This specimen represented a fish which was much larger than documented individuals from other sucker species in the basin.

Two species of minnow are native to the Upper Klamath Basin, the tui chub (Siphateles bicolor) and the blue chub (Gila coerulea). Each of these species was identified in the collections I analyzed. These species are morphologically very similar, thus specimens assigned to Cyprinidae may be from either of these species. Species identification was made using pharyngeal tooth row formula (Bailey and Uyeno 1964). The blue chub has a 
tooth row formula of 2-5, 5-2 where as the tui chub has a single row of four or five pharyngeal teeth on each side. A single pharyngeal recovered from 35KL9-12 could not be identified to species because it was too degraded.

With the exception of $1^{\text {st }}$ and $2^{\text {nd }}$ vertebrae, all vertebrae were assigned to the category of Cyprindae/Catostomidae. First and second vertebrae have characteristics, which allow specific family level identification, however abdominal, caudal and ultimate vertebrae cannot be distinguished between these two families. One specimen from 35KL677 could not be identified as either a $1^{\text {st }}$ or $2^{\text {nd }}$ vertebra and was therefore placed into the Cyprinidae/Catostomidae category as well.

\section{Overall taxonomic representation}

The abundance of identified fish remains varies greatly across collections, with the Williamson River Bridge site having the largest assemblage (3,953 NISP) and Medicine Rock Cave assemblage having the smallest with only 26 specimens. Absolute abundance of specimens is a function of many factors including archaeological field methods (size of mesh screen used; total volume excavated), duration of occupation (e.g., fifty versus several thousand years) and the original human behavior. With some exceptions, preservation of fish remains was good at all of the sites, which probably results in part from the presence of freshwater shellfish remains (e.g., western pearlshell mussel [Margaratifera falcata]), which were noted in all the deposits except that of the Collier 
State Park site. Decomposing shell (and release of calcium carbonate) has the effect of decreasing soil acidity (raising $\mathrm{pH}$ ), which contributes to the survival of bone (Linse 1992).

Salmonid specimens were rare at each archaeological site. Despite overall differences in sample size, the assemblages are consistent in the high representation of catostomids followed by cyprinids, and then salmonids, which were represented by a total of 81 specimens (Table 3; see Appendix 1). Salmonids comprised 8.4\% of the total identified fish bone assemblage at Kawumkan Springs Midden. This low frequency, relative to cyprinid/catostomid remains needs to be addressed, given the potential ramifications of this study for Klamath Basin restoration efforts.

Numerous natural and cultural factors may have affected the abundance of salmonid remains within these assemblages. Bioturbation noted by many of the original investigators at these sites has like damaged some of the original archaeological deposits, either destroying bone completely or making it unidentifiable. This bioturbation is evident in the mixing of radiocarbon dates noted in Chapter 3.

The low frequency of salmonid remains may also result from density mediated destruction. Salmonid bone is much less dense than sucker or minnow bone (Butler and Chatters 1994; Butler 1996). Comparisons of bone mineral content show that salmonid elements are up to 6.5 times less dense than sucker elements. If remains of both 
salmonids and minnow/sucker were deposited at an archaeological site and subjected to similar destructive processes (e.g., cooking/butchering, trampling), salmonid remains would tend to be destroyed with much greater frequency than similar remains of minnow/sucker.

The particular fishery targeted, seasonality of occupation, and scheduling of resource use are important cultural factors which may have influenced the abundance of salmonid remains at project sites. If the main target of the fishery was suckers and site use was linked to migratory cycle of suckers (rather than salmonids), then one would expect suckers to dominate the collections. Another way of considering, if the season of site occupation did not directly correspond to the times when salmon were in rivers, peoples in the region would likely have been engaging in other subsistence activities on the landscape.

It is also important to consider the extent archaeological sampling affects our understanding of past animal distributions, as can be gleaned from site records. This study includes remains from only five sites, which may not be representative of the population of sites and archaeological records from the upper basin. If excavations took place in areas that were not used or were only sporadically used for salmon fishing and processing then their remains would be rare in these contexts. 
Together all of these factors may have greatly influenced the frequency of salmonid remains at these sites. Thus the frequency of salmonid remains should not be taken as a direct measure of salmonid abundance in the rivers above Upper Klamath Lake.

While salmonid remains are rare in project sites, they were identified in each temporal unit recognized reaching back to at least 3,000 BP (Table 3; Figure 3). Thus site records show that salmonids were present throughout the late Holocene.

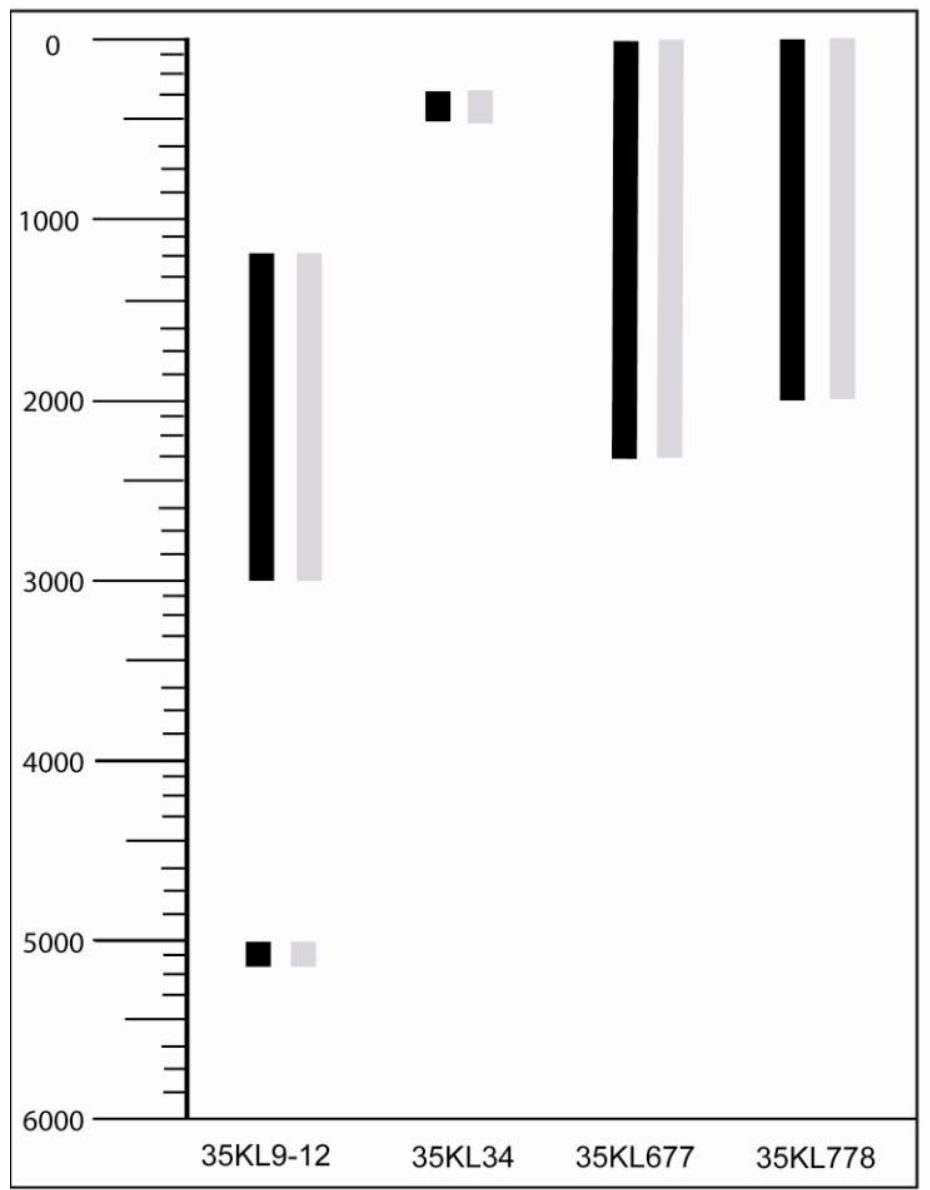

Figure 3. Radiocarbon age ranges of time units (black) and time units where salmonid remains were present (grey). 


\section{Specialized analyses}

A total of 38 specimens or $47.0 \%$ of all salmonid specimens in the collections were submitted for mtDNA study, elemental analyses, or both types of study (Table 4). Twelve specimens received only DNA analysis. All of the specimens submitted for mtDNA analysis also received geochemical analysis.

Table 4 Frequency of salmonid specimens by archaeological site and time period, noting those submitted for specialized analyses

\begin{tabular}{|c|c|c|c|}
\hline Time period & $\begin{array}{r}\text { Total Number } \\
\text { salmonid } \\
\text { specimens }\end{array}$ & DNA & Elemental Analysis \\
\hline \multicolumn{4}{|l|}{$35 \mathrm{KL8}$} \\
\hline \multicolumn{4}{|l|}{ Medicine Rock Cave } \\
\hline Historic $-\sim 7,500 \mathrm{BP}$ & 1 & 1 & 1 \\
\hline \multicolumn{4}{|l|}{ 35KL9-12 } \\
\hline \multicolumn{4}{|l|}{ Kawumkan Spr. Midden } \\
\hline $1200-3000 \mathrm{BP}$ & 6 & 4 & 2 \\
\hline $5060-5100 \mathrm{BP}$ & 2 & 2 & 2 \\
\hline Unknown & 9 & 4 & 4 \\
\hline \multicolumn{4}{|l|}{ 35KL34 } \\
\hline \multicolumn{4}{|l|}{ Collier St. Park } \\
\hline $270-430 \mathrm{BP}$ & 4 & 2 & 1 \\
\hline \multicolumn{4}{|l|}{ 35KL677 } \\
\hline \multicolumn{4}{|l|}{ Williamson R. Bridge } \\
\hline Historic-2400 BP & 14 & 8 & 5 \\
\hline 830-1840 BP & 16 & 8 & 7 \\
\hline Unknown & 2 & 0 & 0 \\
\hline \multicolumn{4}{|l|}{ 35KL778 } \\
\hline \multicolumn{4}{|l|}{ Bezuksewas Village } \\
\hline Historic (AD 1860+) & 16 & 4 & 2 \\
\hline $90-560 \mathrm{BP}$ & 9 & 5 & 4 \\
\hline $680-2000 \mathrm{BP}$ & 2 & 0 & 0 \\
\hline TOTAL & 81 & 38 & 28 \\
\hline
\end{tabular}




\section{mtDNA}

These results are taken from Yang and Speller's technical report presented in Appendix 2.

Mitochondrial DNA was successfully amplified from 31 of 38 samples, a success rate of 81.6\% (Table 5). According to lab protocols, species was assigned to a sample only if it matched identically or very closely with published reference sequences, and if no other evidence, including reproducibility tests or additional sequencing of the same sample indicated a different species.

The results of the DNA amplification and sequences suggest that the recovered salmonid DNA is authentic. The contamination controls undertaken in this study were successful at eliminating any systematic contamination as no PCR amplification was observed blank extracts and PCR negative controls. D-loop and cytb sequences from all samples yielded the same species identities, suggesting that there was no cross-contamination between samples. Repeat PCR amplifications and sequencing were conducted successfully for five samples (KSM-13, KSM-16, WRB-12, WRB-26, WRB-29) and yielded consistent results in all cases.

Two species of Pacific salmon and trout were identified through mtDNA analysis. All PCR reactions yielded salmonid sequences, which matched either identically, or within a few base pairs, with Genbank reference sequences for O. mykiss and $O$. tshawytscha (see Table 5). Of the successfully sequenced samples, 25 were identified as $O$. mykiss 
Table 5 mtDNA results

\begin{tabular}{|c|c|c|c|c|c|}
\hline SFU Code & CatNo & Cytochrome b ID & D-loop ID & $\begin{array}{l}\text { D-loop } \\
\text { haplotype }\end{array}$ & SMC3/4 ID \\
\hline SBC37 & MRS-1 & NA & NA & & NA \\
\hline SBC29 & KSM-4 & O. mykiss & NA & No Hap ID & \\
\hline SBC30 & KSM-5 & O. mykiss & O. mykiss & ST2 & \\
\hline SBC31 & KSM-7 & O. mykiss & O. mykiss & ST2 & \\
\hline SBC32 & KSM-8 & O. mykiss & O. mykiss & ST2 & \\
\hline SBC33 & KSM-9 & NA & O. tshawytscha & & O. tshawytscha \\
\hline SBC34 & KSM-10 & NA & NA & & NA \\
\hline SBC54 & KSM-13 & O. mykiss * & O. mykiss * & ST1 & \\
\hline SBC35 & KSM-14 & O. mykiss & O. mykiss & ST1 & \\
\hline SBC55 & KSM-15 & O. mykiss & O. mykiss & ST1 & \\
\hline SBC36 & KSM-16 & O. tshawytscha* & O. tshawytscha & & \\
\hline SBC27 & CSP-1 & NA & NA & & NA \\
\hline SBC28 & CSP-2 & NA & NA & & NA \\
\hline SBC38 & WRB-1 & O. mykiss & O. mykiss & ST2 & \\
\hline SBC39 & WRB-3 & O. mykiss & O. mykiss & ST2 & O. mykiss \\
\hline SBC40 & WRB-6 & O. mykiss & O. mykiss & ST2 & \\
\hline SBC56 & WRB-7 & O. mykiss & O. mykiss & ST1 & \\
\hline SBC57 & WRB-11 & NA & NA & & NA \\
\hline SBC41 & WRB-12 & O. mykiss* & O. mykiss* & ST2 & \\
\hline SBC42 & WRB-14 & O. tshawytscha & O. tshawytscha & & \\
\hline SBC43 & WRB-16 & O. tshawytscha & O. tshawytscha & & \\
\hline SBC58 & WRB-19 & O. mykiss & O. mykiss & ST1 & \\
\hline SBC44 & WRB-20 & O. mykiss & O. mykiss & ST1 & \\
\hline SBC45 & WRB-21 & O. mykiss & O. mykiss & No Hap ID & \\
\hline SBC46 & WRB-22 & NA & NA & & NA \\
\hline SBC47 & WRB-24 & O. mykiss & O. mykiss & ST2 & \\
\hline SBC59 & WRB-26 & O. mykiss * & O. mykiss & ST2 & O. mykiss \\
\hline SBC48 & WRB-29 & O. mykiss * & O. mykiss & ST2 & \\
\hline SBC49 & WRB-30 & O. mykiss & O. mykiss & ST1 & \\
\hline SBC21 & BVS-3 & O. mykiss & O. mykiss & ST1 & \\
\hline SBC22 & BVS-4 & O. mykiss & O. mykiss & ST2 & \\
\hline SBC23 & BVS-11 & O. mykiss & O. mykiss & ST2 & \\
\hline SBC24 & BVS-13 & O. mykiss & O. mykiss & ST2 & \\
\hline SBC51 & BVS-14 & O. mykiss & O. mykiss & ST2 & \\
\hline SBC25 & BVS-15 & O. mykiss & $\mathrm{PSQ}^{* *}$ & No Hap ID & \\
\hline SBC52 & BVS-17 & NA & $\mathrm{NA}$ & & NA \\
\hline SBC53 & BVS-20 & O. tshawytscha & O. tshawytscha & & \\
\hline SBC26 & BVS-22 & O. tshawytscha & O. tshawytscha & & \\
\hline
\end{tabular}

(redband/ steelhead trout) and six as O. tshawytscha (Chinook salmon) (Table 6).

Species identities obtained through this analysis of different mtDNA fragments (i.e. cytb

and d-loop), matched in all cases, supporting the authenticity of the identifications. 
All six samples identified as $O$. tshawytscha, displayed identical cytb and d-loop haplotypes. Twenty-five samples identified as $O$. mykiss based on cytb displayed identical haplotypes, though two different d-loop haplotypes were identified (haplotypes ST1 and ST2). D-loop haplotypes were identified for 22 of the 25 O. mykiss samples for which the d-loop could be sequenced. Three $O$. mykiss samples did not yield adequate DNA for a d-loop haplotype identification: $O$. mykiss sample KSM-4 failed to amplify the long d-loop fragment, while the d-loop fragments obtained for BVS-15 and WRB-21 were not sufficiently clear to make a haplotype identification. One O. mykiss sample, failed to amplify the cytb fragment.

The two O. mykiss haplotypes (ST1 and ST2) differ at four different base pair positions, but are consistent with the range of variation present in modern populations of North American Rainbow Trout populations (Bagley and Gall 1998). O. mykiss haplotype ST1 was identified in 8 archaeological salmonid samples, including those recovered from Bezuksewas Village, Kawumkan Springs Midden, and Williamson River Bridge. Haplotype ST1 has also been identified in a modern coastal rainbow trout (O. mykiss) individual collected from Skookumchuck River, Washington (Genbank accession DQ288271 Brown et al. 2006), as well as coastal steelhead populations from Mad River Hatchery, CA and Coralitos Creek CA (Haplotypes RTDL06, RTDR07, Bagley and Gall 1998). O. mykiss haplotype ST2 was identified in 14 of the archaeological remains, including those from Bezuksewas Village, Kawumkan Springs Midden, and Williamson 
River Bridge. This haplotype has also been observed in individuals from an inland rainbow trout population at Eagle Lake Hatchery, CA (Haplotype RTDL32 in Bagley and Gall 1998).

The relationship of these $O$. mykiss haplotypes to Klamath River anadromous steelhead and inland redband trout cannot be assessed based on the present data. Though recent studies have examined the genetic variability of Klamath basin trout populations through enzyme encoding loci (Currens et al. 2009) and microsatellite loci (Pearse et al. submitted), comparable mitochondrial DNA sequences for these populations are not yet available. Due to a lack of comparative modern data, the ancient mtDNA analysis cannot identify these archaeological salmon remains as either steelhead or redband trout.

Table 6 Archaeological specimens submitted for DNA analysis and results

\begin{tabular}{|c|c|c|c|c|}
\hline Site & $\begin{array}{r}\text { Samples } \\
\text { submitted } \\
\text { for DNA } \\
\end{array}$ & O. mykiss & O. tshawytscha & No results \\
\hline \multicolumn{5}{|l|}{ 35KL8 } \\
\hline Medicine Rock Cave & 1 & 0 & 0 & 1 \\
\hline \multicolumn{5}{|l|}{ 35KL9-12 } \\
\hline Kawumkan Spr. Midden & 10 & 7 & 2 & 1 \\
\hline \multicolumn{5}{|l|}{ 35KL34 } \\
\hline Collier St. Park & 2 & 0 & 0 & 2 \\
\hline \multicolumn{5}{|l|}{ 35KL677 } \\
\hline Williamson R. Bridge & 16 & 12 & 2 & 2 \\
\hline \multicolumn{5}{|l|}{ 35KL778 } \\
\hline Bezuksewas Village & 9 & 6 & 2 & 1 \\
\hline Total & 38 & 25 & 6 & 6 \\
\hline
\end{tabular}

Preservation of DNA was the best at Kawumkan Springs Midden where all but one specimen yielded DNA sufficient for species identification (Table 6). None of the samples submitted for analysis from Collier State Park site or Medicine Rock Cave 
yielded any DNA, which could be sequenced. The lack of freshwater mussel shell within some of the deposits may have contributed to the degradation of DNA and therefore the lack of results. However, a single specimen from the Williamson River Bridge site taken from a large mussel shell feature (Feature 1) did not provide DNA results so the presence of shell here did not promote DNA preservation.

\section{Geochemistry}

\section{$\underline{\text { Water } \mathrm{Sr}: \mathrm{Ca}}$}

Analysis of the thirteen Upper Klamath Basin water samples (Table 7) suggests $\mathrm{Sr}: \mathrm{Ca}$ is

Table 7 Sr:Ca ratios in Upper Klamath Basin waters (bold indicates samples adjacent to archaeological sites

\begin{tabular}{lccr}
\hline & \multicolumn{2}{c}{ UTM (Zone 10) } & Sr:Ca mmol/mol \\
\hline Sample Location & 4729002 & 582519 & 3.63 \\
Wood River & & & $\mathbf{2 . 8 1}$ \\
Collier St Park & & & $\mathbf{3 . 3 8}$ \\
Medicine Rock Cave & & & $\mathbf{3 . 3 4}$ \\
Kawumkan Spr. Midden & & & $\mathbf{3 . 3 8}$ \\
Bezuksewas Village & & & 3.50 \\
Agency Lake & 4709124 & 587890 & $\mathbf{3 . 4 0}$ \\
Williamson River Bridge & & & $\mathbf{3 . 5 7}$ \\
Beatty Curve & & & 3.55 \\
Upper UKL & 4698036 & 577208 & 3.49 \\
Middle UKL & 4685250 & 587170 & 3.61 \\
Lower UKL & 4676578 & 598287 & 3.63 \\
Link River & 4675232 & 599422 & 3.33 \\
Klamath River & 4664569 & 588577 & . \\
\hline
\end{tabular}

Note location information for archaeological sites has been omitted due to issues of cultural sensitivity 
homogeneous across the region sampled (mean $=3.43 ; \mathrm{SD}=0.22$ ), with no discernible latitudinal trends in ratios. The Williamson River at Collier State Park had the lowest strontium to calcium ratio $(2.81 \mathrm{mmol} / \mathrm{mol})$ and the Link River had the highest $(3.63$ $\mathrm{mmol} / \mathrm{mol})$.

\section{$\underline{\text { Bone/otolith Sr:Ca }}$}

Geochemical data were obtained for pairs of modern otolith and bone samples (Table 8). Regression analysis suggested the relationship between the variables was best described as curvilinear and a polynomial line was fit to the points $\left(\mathrm{R}^{2}=0.99\right)($ Figure 4$)$.

$$
\begin{aligned}
& \text { Eq. } 1 \quad \mathrm{y}=-0.242( \pm 0.057) \mathrm{x}^{2}+1.319( \pm 0.19) \mathrm{x}-0.523( \pm 0.15) \\
& \text { where } \mathrm{y}=\mathrm{Sr}: \mathrm{Ca} \mathrm{a}_{\text {bone }} \text { and } \mathrm{x}=\mathrm{Sr}: \mathrm{Ca}_{\text {otolith }} .
\end{aligned}
$$

Equation 1 was used to determine the threshold value distinguishing marine versus freshwater residence (Figure 4). Marine otolith Sr:Ca values for Chinook salmon typically range from 1.5 to $2.5 \mathrm{mmol} / \mathrm{mol}$ (Zimmerman 2005; Miller et al. 2010). Using $1.5 \mathrm{mmol} / \mathrm{mol}$ as a lower limit for marine residence, Eq. 1 yields a value of 0.92 $\mathrm{mmol} / \mathrm{mol}$ for bone $\mathrm{Sr}: \mathrm{Ca}$ This provides a lower limit, below which a bone can be presumed to be from a fish residing in freshwater and above which they can be linked to fish with a marine life history phase. 
Table $8 \mathrm{Sr}$ :Ca ratios for pairs of modern otolith/bone samples*

\begin{tabular}{llrr}
\hline Catalog No. & Species & $\begin{array}{l}\text { Otolith Sr:Ca } \\
(\mathbf{m m o l} / \mathbf{m o l})\end{array}$ & \multicolumn{2}{c}{$\begin{array}{l}\text { Bone Sr:Ca } \pm \text { SE } \\
(\mathbf{m m o l} / \mathbf{m o l})\end{array}$} \\
\hline Mod-1 & O. mykiss & $\mathrm{n} / \mathrm{a}$ & $0.60 \pm 0.03$ \\
& O. mykiss $( \pm$ SE) & $1.06 \pm 0.02$ & $\mathrm{n} / \mathrm{a}$ \\
Mod-5 & O. tshawytscha & 2.14 & $1.20 \pm 0.01$ \\
Mod-6 & O. tshawytscha & 2.45 & $1.25 \pm 0.03$ \\
Mod-7 & O. tshawytscha & 2.40 & $1.27 \pm 0.02$ \\
Mod-8 & O. tshawytscha & 2.18 & $1.18 \pm 0.01$ \\
Mod-9 & O. tshawytscha & 2.19 & $1.22 \pm 0.03$ \\
\hline
\end{tabular}

*While the otolith/bone pairs for $O$. tshawytscha are from individual fish, the bone/otolith values for $O$. mykiss (redband trout) are derived from two sources. The bone value is based on one fish (Mod-1) from Upper Klamath Lake. The otolith value is based on an average of 10 otoliths from Kirk Springs and Spring Creek. We justify using these two sources to examine the relationship between otolith/bone $\mathrm{Sr}: \mathrm{Ca}$ in $O$. mykiss (redband trout) given the low variability in Sr:Ca ratios in the Upper Klamath Basin (Table 9).

To provide a second estimate for a threshold value for marine bone $\mathrm{Sr}: \mathrm{Ca}$, I examined the relationship between bone and water Sr:Ca. In this analysis, the five samples of modern Chinook salmon bone paired with mean marine water Sr:Ca value $(8.5 \mathrm{mmol} / \mathrm{mol})$; and one sample of bone from redband trout collected in freshwater, paired with mean freshwater Sr:Ca ratio based on our field samples (Figure 5). Additionally, I used a mixing curve generated by Miller and colleagues (2010) for water Sr:Ca in relation to salinity within the Klamath River basin (Miller et al. 2010). This curve used the mean observed freshwater $\mathrm{Sr}(52.9 \mathrm{ppb})$ and $\mathrm{Ca}$ (7.04 ppm) and reported mean marine $\mathrm{Sr}$ (7.1 $\mathrm{ppb})$ and $\mathrm{Ca}(415 \mathrm{ppm})$ concentrations as the freshwater and marine end members, respectively (Figure 6). Combined, these two relationships (Figure 5 and 6) indicate that bone Sr:Ca would attain values $\sim 0.90 \mathrm{mmol} / \mathrm{mol}$ upon exposure to marine levels of $\mathrm{Sr}: \mathrm{Ca}$, (i.e., salinities $>1$ and water $\mathrm{Sr}: \mathrm{Ca}>6 \mathrm{mmol} / \mathrm{mol}$ ). Therefore, examination of modern bone and water Sr:Ca provides an estimate of expected bone Sr:Ca for freshwater 


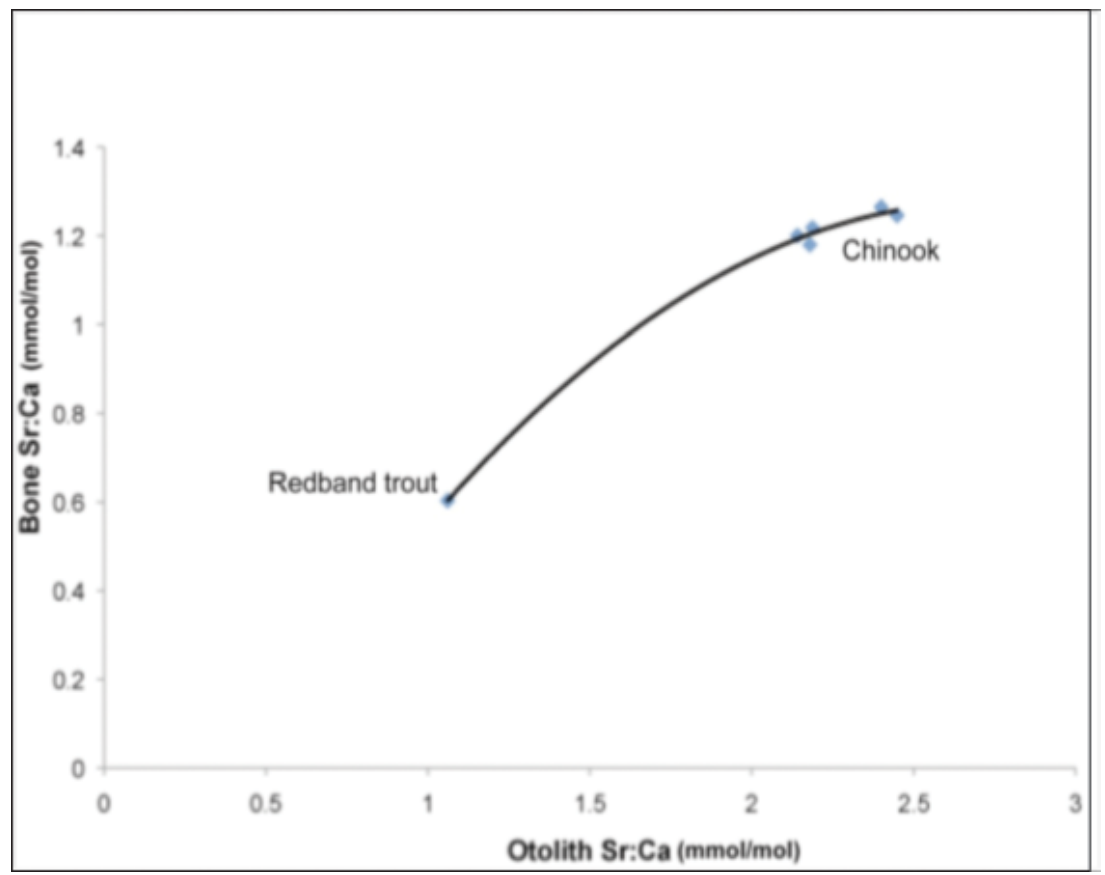

Figure 4 Relationship between Sr:Ca in modern bone and otolith (see Table 8 for values)

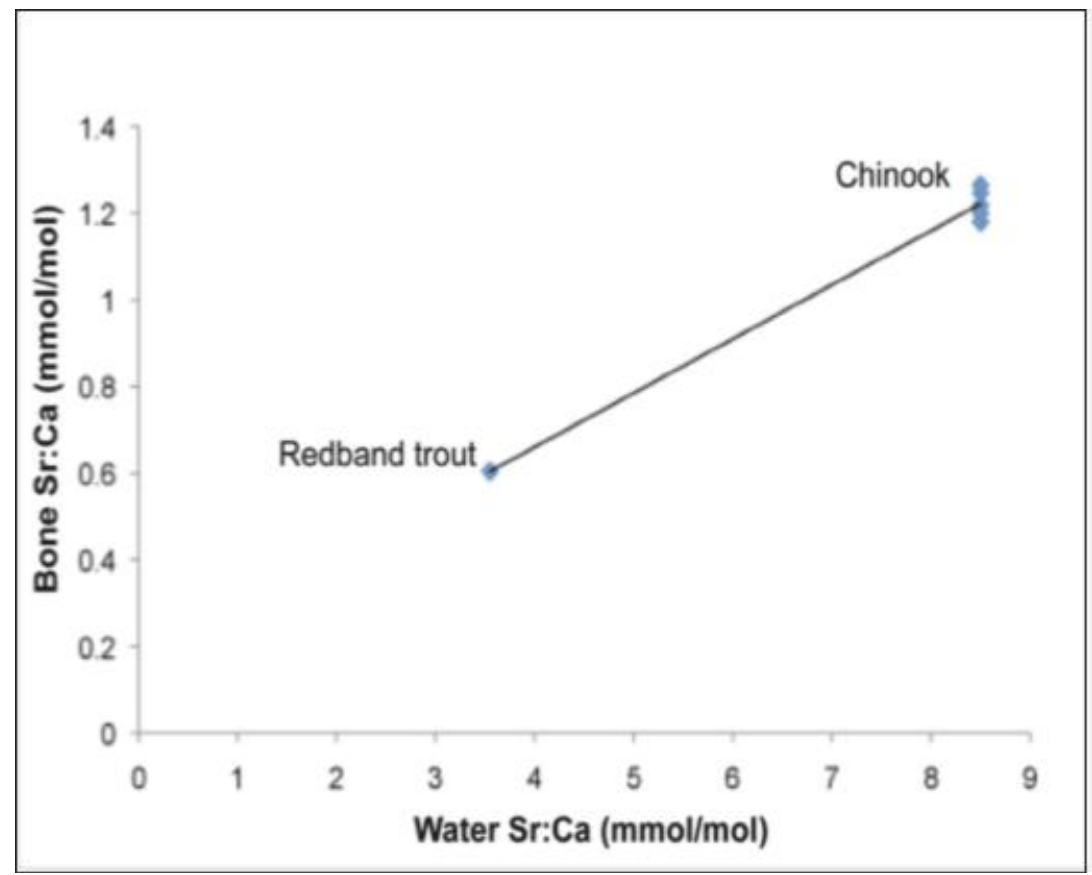

Figure 5 Relationship between water and bone Sr:Ca. Samples for freshwater represent mean value for UKB (see Table 7) versus modern $O$. mykiss (mod-1) and marine water $(8.5)$ versus bone from modern $O$. tshawytscha $(\bmod -5,6,7,8,9)$ 


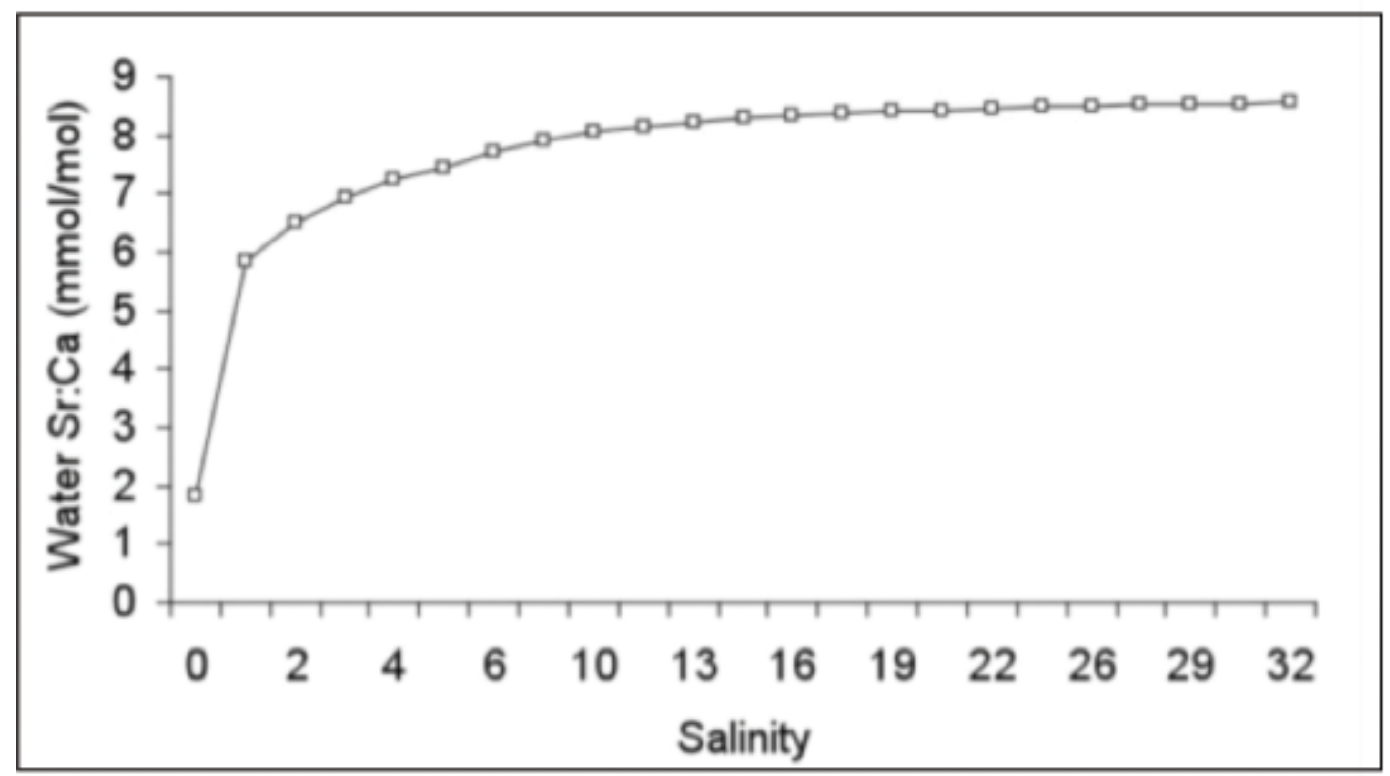

Figure 6 Predicted relationship between salinity and water Sr:Ca based on known values for Klamath River and marine Sr and Ca concentrations. Note: water Sr:Ca reaches $\sim 6 \mathrm{mmol} / \mathrm{mol}$ at low salinities values for Klamath River and marine $\mathrm{Sr}$ and Ca concentrations. Note that water Sr:Ca reaches $\sim 6 \mathrm{mmol} / \mathrm{mol}$ at low salinities.

residents within the Klamath River basin (i.e., less than $\sim 0.9 \mathrm{mmol} / \mathrm{mol}$ ) and provides further support for the marine threshold of $0.92 \mathrm{mmol} / \mathrm{mol}$ (Figure 4).

\section{Archaeological Bone Sr:Ca}

Sr:Ca ratios were obtained for the 41 archaeological specimens (Table 9). Sr:Ca ranged from $0.74( \pm 0.01) \mathrm{mmol} / \mathrm{mol}(\mathrm{KSM}-4)$ to $3.21( \pm 0.03) \mathrm{mmol} / \mathrm{mol}(\mathrm{WRB}-24)$ (Table 9). Using the $0.92 \mathrm{mmol} / \mathrm{mol}$ threshold value derived from modern samples, 25 of the specimens $(89.3 \%)$ yielded Sr:Ca values indicative of anadromy or marine residence (Table 9). Mean Sr:Ca ratios for these specimens is $1.41 \pm 0.230 \mathrm{mmol} / \mathrm{mol}$. A single value above $2.09 \mathrm{mmol} / \mathrm{mol}$ was observed in sample WRB-24 (3.21 mmol/mol). This sample value was >3 SD from the overall mean for inferred marine $\mathrm{Sr}$ : $\mathrm{Ca}$ in 
archaeological samples; therefore, it was considered aberrant and excluded from further analysis. Except for the Collier State Park assemblage with only one sample studied, specimens with Sr:Ca values indicating anadromy were observed within each collection.

Table 9 Sr:Ca values for archaeological specimens and assigned residence pattern

\begin{tabular}{|c|c|c|c|}
\hline Site Name & Sample No. & $\begin{array}{r}\text { Bone Sr:Ca } \pm \text { S.E. } \\
(\mathrm{mmol} / \mathrm{mol})\end{array}$ & Residence Pattern \\
\hline \multicolumn{4}{|l|}{$35 \mathrm{KL8}$} \\
\hline \multicolumn{4}{|l|}{ Medicine Rock Cave } \\
\hline & MRS-1 & $1.90 \pm 0.03$ & Anadromous \\
\hline \multicolumn{4}{|l|}{ 35KL9-12 } \\
\hline \multicolumn{4}{|l|}{ Kawumkan Spr. Midden } \\
\hline & KSM-4 & $0.74 \pm 0.01$ & Freshwater/Resident \\
\hline & KSM-5 & $2.00 \pm 0.04$ & Anadromous \\
\hline & KSM-7 & $0.90 \pm 0.05$ & Freshwater/Resident \\
\hline & KSM-8 & $1.20 \pm 0.01$ & Anadromous \\
\hline & KSM-9 & $0.98 \pm 0.01$ & Anadromous \\
\hline & KSM-13 & $1.52 \pm 0.00$ & Anadromous \\
\hline & KSM-15 & $1.05 \pm 0.05$ & Anadromous \\
\hline & KSM-16 & $1.19 \pm 0.01$ & Anadromous \\
\hline \multicolumn{4}{|l|}{ 35KL34 } \\
\hline \multicolumn{4}{|l|}{ Collier St. Park } \\
\hline & CSP-1 & $0.85 \pm 0.03$ & Freshwater/Resident \\
\hline \multicolumn{4}{|l|}{ 35KL677 } \\
\hline \multicolumn{4}{|l|}{ Williamson R. Bridge } \\
\hline & WRB-1 & $1.18 \pm 0.02$ & Anadromous \\
\hline & WRB-6 & $1.34 \pm 0.03$ & Anadromous \\
\hline & WRB-7 & $1.49 \pm 0.05$ & Anadromous \\
\hline & WRB-11 & $1.34 \pm 0.04$ & Anadromous \\
\hline & WRB-12 & $1.48 \pm 0.05$ & Anadromous \\
\hline & WRB-14 & $2.09 \pm 0.13$ & Anadromous \\
\hline & WRB-16 & $1.39 \pm 0.03$ & Anadromous \\
\hline & WRB-19 & $1.68 \pm 0.16$ & Anadromous \\
\hline & WRB-20 & $2.05 \pm 0.10$ & Anadromous \\
\hline & WRB-24* & $3.21 \pm 0.03$ & Anadromous \\
\hline & WRB-26 & $1.31 \pm 0.06$ & Anadromous \\
\hline & WRB-29 & $1.16 \pm 0.06$ & Anadromous \\
\hline \multicolumn{4}{|l|}{ 35KL778 } \\
\hline \multicolumn{4}{|l|}{ Bezuksewas Village } \\
\hline & BVS-3 & $1.02 \pm 0.03$ & Anadromous \\
\hline & BVS-11 & $1.23 \pm 0.06$ & Anadromous \\
\hline & BVS-14 & $0.97 \pm 0.14$ & Anadromous \\
\hline & BVS-17 & $1.00 \pm 0.01$ & Anadromous \\
\hline & BVS-20 & $1.12 \pm 0.01$ & Anadromous \\
\hline & BVS-22 & $1.27 \pm 0.06$ & Anadromous \\
\hline
\end{tabular}

* Sr:Ca ratio > 3 SD above value of archaeological otoliths inferred to be from anadromous fish; 
eeconsidered aberrant and excluded from analysis

Three of the 28 bone samples $(10.7 \%)$ were assigned to freshwater residence pattern

(Table 11). The mean Sr:Ca values for the freshwater specimens is $0.83 \pm 0.09 \mathrm{mmol} / \mathrm{mol}$.

Two of these specimens were from Kawumkan Springs Midden (KSM-4, KSM-7) and the third specimen assigned to freshwater residence was the only specimen from Collier State Park (CSP-1).

\section{$\underline{\text { Diagenesis }}$}

Diagenesis constitutes the post-depositional or post-mortem modification of the chemical and/or physical structure of an object. Strontium diagenesis has been documented in numerous studies including archaeological ones (e.g. Budd et al. 2000). Because this process could artificially alter the Sr:Ca ratio used to determine life history characteristics in this study, it was necessary to evaluate its potential role in modifying Sr:Ca values in the archaeological sites.

Butler et al. (2010) evaluated the role of diagenesis in structuring the Sr:Ca values presented here. Their study found no relationship between Sr:Ca values through time. Additionally, their study did not find any specific patterning of Sr:Ca values at each of the archaeological sites considered here. 


\section{Towards Sr:Ca validation}

Together Sr:Ca values and genetic identifications help to address the validity of the $\mathrm{Sr}: \mathrm{Ca}$ method for identifying anadromous residence (Table 10). The two species of $O$. mykiss identified using mtDNA have varied life histories. O. tshawytscha is a species that without exception is anadromous although some variability exists in maturity of both seaward migration and homing (Quinn 2005). All of the specimens identified genetically as Chinook which were also subjected to geochemical analysis yielded Sr:Ca ratios above the $0.92 \mathrm{mmol}: \mathrm{mol}$ freshwater cutoff value. O. mykiss has two forms which have very different life histories, one that is anadromous (steelhead) and one that remains in freshwater (redband or rainbow trout) (Quinn 2005). Both of these life history variations were identified as O. mykiss, two specimens yielded Sr:Ca values lower than the freshwater cutoff and sixteen were determined to be anadromous.

Together the identification of Sr:Ca values indicative of only anadromy in O. tshawytscha and both freshwater residence and anadromy in O. mykiss suggest this geochemical method provides an accurate method for discriminating between these two distinct life histories. 
Table 10 Number of identified salmonid specimens to finest taxonomic level as identified by mtDNA with geochemical results

\begin{tabular}{lccccc}
\hline & & \multicolumn{2}{c}{ O. tshawytscha } & \multicolumn{2}{c}{ O. mykiss } \\
Site & Total & Sr:Ca & Sr:Ca & Sr:Ca & Sr:Ca \\
Time period & Salmonids & $>\mathbf{0 . 9 2}$ & $\leq \mathbf{0 . 9 2}$ & $>\mathbf{0 . 9 2}$ & $\leq \mathbf{0 . 9 2}$ \\
\hline
\end{tabular}

$35 \mathrm{KL8}$

Medicine Rock Cave

$\begin{array}{llllll}\text { Historic }-\sim 7,500 \mathrm{BP} & 1 & 0 & 0 & 0 & 0\end{array}$

35KL9-12

Kawumkan Spr. Midden

$\begin{array}{llllll}\text { 1200-3000 BP } & 6 & 0 & 0 & 1 & 1 \\ 5060-5100 \text { BP } & 2 & 1 & 0 & 1 & 0 \\ \text { Unknown } & & & & & \\ \text { (Lev. } 1 \& 4) & 9 & 1 & 0 & 2 & 1\end{array}$

35KL34

Collier St. Park

$$
270-430 \mathrm{BP}
$$

4

0

0

0

0

35KL677

Williamson R. Bridge

$\begin{array}{lrrrrr}\text { Historic-2400 BP } & 16 & 2 & 0 & 4 & 0 \\ \text { 830-1840 BP } & 14 & 0 & 0 & 5 & 0 \\ \text { Unknown } & 2 & 0 & 0 & 0 & 0\end{array}$

35KL778

Bezuksewas Village

\begin{tabular}{llrrrrr} 
& Historic $(A D$ 1860+) & 14 & 2 & 0 & 2 & 0 \\
& $90-560 \mathrm{BP}$ & 12 & 0 & 0 & 1 & 0 \\
& $680-2000 \mathrm{BP}$ & 1 & 0 & 0 & 0 & 0 \\
\hline TOTAL & & 81 & 6 & 0 & 16 & 2 \\
\hline
\end{tabular}




\section{Chapter 6: Salmonids in the Upper Klamath Basin: Local Catch or Trade?}

Previous chapters have reviewed DNA and geochemical evidence which demonstrates that the remains of anadromous salmonids were recovered from archaeological sites above Upper Klamath Lake. It is possible that archaeological fish remains of salmon and trout from these sites represent fish that were caught elsewhere and either traded or otherwise transported in to the area. There is a well-documented history of salmon trade in the Pacific Northwest (e.g., Boyd 1996), and this certainly is a plausible scenario for the introduction of salmonid remains into these archaeological sites.

In this chapter I evaluate two hypotheses to account for the presence of salmonid remains in archaeological assemblages above Upper Klamath Lake.

The Local Catch Hypothesis - Pacific salmon and trout represented in the studied archaeological assemblages were caught locally above Upper Klamath Lake.

The Trade (or Transport) Hypothesis - Pacific salmon and trout present in the studied archaeological assemblages were traded into the area from elsewhere. 
I evaluate these hypotheses by reviewing ethnographic and archaeological data and developing expectations for archaeological expressions of trade and local catch. I then examine the salmonid assemblages from each Upper Klamath Basin site in light of these expectations to establish if the assemblages were the result of trade or local catch. How the assemblages meet these expectations is addressed using two approaches. First, I compare data from two sites against datasets which model expectations for each hypothesis. Second, I examine the proportional representation of skeletal elements from each site. These two techniques are used here because each affords a slightly different view of the representation of the parts of fish bodies represented by the bones included in the assemblages in this study.

\section{Expectations for salmonid trade vs. local catch}

Fish trade in the Pacific Northwest has been well documented in both historic and ethnographic literature (e.g., Gatschet 1890; Boyd 1996; Deur 2003). The Dalles on the Columbia River was not only an important location for salmon fishing but was also an important location for meeting and exchange (Boyd 1996). Salmon that had been caught and dried in the area were traded to tribes from elsewhere on the Columbia Plateau, including two groups like the Nez Perce and Umatilla who had regular access to salmon runs. Like most other Pacific Northwest tribes, people from the Klamath Basin were known to trade at The Dalles (Gatschet 1890; Spier 1930; Boyd 1996). 
The Dalles is only one source of salmon that could have been traded into the Upper Klamath Basin. The Lower Klamath Basin is much closer and has well documented salmon runs, which are said to have been the third largest on the west coast of the United States, after those of the Columbia and Sacramento Rivers (U.S Fish and Wildlife 2010). According to Deur (2003:8), Klamath Canyon, south of the outlet of Klamath Lake, was an important location for salmon fishing and salmon trade. Based on informant testimony recorded by Deur, people from the Upper Klamath Basin did not have to go to this area for salmon, as these fish could be caught locally, but the area below the lake served as a hub for social reasons. The salmon trade here even attracted groups from the Great Basin such as the Achumawi and the Paiute. Deur (2003) also notes that there is some ethnographic evidence for precontact salmon trade with peoples of the Rogue River Basin. Peoples who inhabited the Klamath Basin also likely fished in many of the areas where trade was popular and may have therefore simply transported fish from these areas into the Klamath Basin. Certainly, fish from nearby sources could have been traded into villages farther up in the basin above Upper Klamath Lake.

Just as fish trade is common throughout the Pacific Northwest, methods of fish butchery and processing are as well. Many different native groups removed salmon heads from trunks, because heads are the oiliest part of the fish and contribute to spoilage (Butler 1990; Hoffman et al. 2000). Butler's review of ethnographic literature related to salmon processing across the Northwest Coast indicates that heads were removed soon after capture, and were sometimes processed for immediate consumption. The 
Sanpoil/Nespelum of the Upper Columbia River cut the sides of the body into two sections, while other groups like the Puyallup left the trunk as a single piece. At The Dalles, fish were commonly either filleted or ground up for trade (Boyd 1996). Deur's (2003:24) Klamath tribal informants indicated that large fish, including salmon were cut into fillets by slicing the fish through the back and leaving the belly intact. Spier (1930:155) echoes this, noting that "The fish is split down the back, entrails and backbone removed, the head cutoff and the flanks open." Fish were then dried either on large rocks or racks. Some of the fish were then ground up to make kamalsh, which was a staple of the Klamath diet (Spier 1930; Deur 2003). This ethnographic evidence suggests that archaeological assemblages that result from trade or transport of fish for storage will tend to be comprised of skeletal elements associated with the trunk and should not contain many, if any, skeletal elements from the head.

In developing expectations for transported fish, it is important to consider the monitoring perspective and understand how the assemblage of interest fits into a general land use and resource procurement system (Thomas and Mayer 1983). For example, residential sites are likely to have remains representing the most valuable portions of the animal (i.e., trunks in fish). Conversely, where fish are caught and processed for transportation lower value items (i.e., heads in fish) will be more likely to be found because these are discarded to increase one's ability to transport better pieces of the animal. 
Processing tends to occur at fishing stations, and these locations would most likely contain discarded heads, which were commonly consumed at sites where these fish were butchered. The discard of head bones would be associated with their onsite discard and/or immediate consumption. Moreover, by their nature, task specific camps for fishing would tend not to contain remains of fish traded in from elsewhere (Binford 1980) and should, by definition, be linked with locally caught fish. This fact may make fishing stations ideal for establishing whether fish were captured locally. Based on these data, I expect that archaeological fishing station assemblages would yield a high number of head bones and a relatively low number of trunk elements. Specialized fishing camps would provide the best evidence for the Local Catch Hypothesis because they would represent direct procurement with no introduction from elsewhere.

Villages, on the other hand, are a less ideal situation from which to evaluate local catch versus trade and/or transport. Villages are often gathering places for people and goods transported from a distant location and which are not part of the site's typical catchment (Binford 1980). However, the methods used to process locally available resources for transport and storage in sites of long-term occupation are the same as those observed in trade. Thus, I expect that village fish assemblages resulting from local catch would be dominated by trunk elements, but may contain some head parts as well. This reduces the value of faunal assemblages from villages for distinguishing local catch from trade. 
Each of the sites included in this study are located directly along a major waterway above Upper Klamath Lake and allowed direct access to fish. The distinctions between village and specialized fish camp assemblages of these Upper Klamath Basin sites may not be as great as the expectations outlined above. For example, inhabitants of Bezuksewas Village likely would have taken fish as they passed the village. Spier (1930:14) notes that this site was known as a spring fishing location. Thus, cranial elements and trunks of locally caught fish would be expected at this site in addition to fish bodies transported into the village from the surrounding landscape.

To move from these expectations to archaeological materials, I need to consider parts of the fish body and associated skeletal elements. As others have done (e.g., Butler 1990), I examine body part representation by distinguishing cranial from postcranial remains, basically heads versus the trunk, including paired fins. I have chosen to do this for two reasons. First, the sample sizes are very small in each of the salmonid assemblages and increasing the number of categories makes analysis less meaningful. Second, fin elements are often said to ride along with trunks, thus their inclusion in a distinct category would not be useful in this study.

To quantify the number of salmonid elements that were recovered from each site I calculated the minimum number of elements (MNE). The MNE is derived by focusing on identified specimens that retain unique, non-repetitive landmarks (see Chapter 4 for discussion). The MNE value allows quantification of skeletal elements and is less 
influenced by fragmentation than NISP (Grayson 1984; Lyman 2008). I used the MNE value to calculate the minimum animal unit (MAU).

The MAU can be used to assess proportional representation of a portion of an animal and is calculated by dividing the MNE by the number of times a skeletal element is repeated in the body of an animal. MAUs were scaled to the largest MAU value by dividing them by this larger number. This decimal value was then multiplied by 100 to generate $\%$ MAU which is also known as "survivorship." For example, if 14 opercles $(\mathrm{MNE}=14)$ and 28 cleithra $(\mathrm{MNE}=28)$ were observed in an assemblage this number would be divided by two (the number of times each skeletal element is repeated on each fish). The opercles represent seven fish, yet the cleithra represent 14 fish. To calculate MAU values for each element, the MNE must be divided by the largest number of fish possibly represented by the assemblage (i.e., 14) and then multiplied by 100 to create a percentage. Thus, the $\% \mathrm{MAU}$ for the cleithrum is $100 \%$ and the $\% \mathrm{MAU}$ for the opercle is $50 \%$. In this scenario the cleithrum proportionally dominates the assemblage.

Butler (1993) showed that a complete salmon is roughly $42 \%$ cranial elements and $58 \%$ postcranial elements (Figure 7). This "standard skeleton" provides a control against which to evaluate archaeological assemblages. If for example, skeletal remains are found in roughly the same proportion as noted in the standard skeleton, I would argue that the assemblage resulted from deposition of complete fish. However, if proportionally more 
cranial remains than postcranial remains are found in comparison to the standard skeleton, I would argue that fish heads were preferentially discarded at the site.

To provide a "control" sample for transported fish, I include salmon records from Housepit 7 at the Keatley Creek site. The site is a large pithouse village located on the Canadian Plateau on a landform high above the Fraser River near the town of Lillooet (Hayden 1993). The Fraser River has well documented salmon runs that were important ethnographically in the region (Romanoff 1993). The salmonid assemblage from Housepit 7 has been interpreted to represent fish caught and processed on the Fraser River far below the site and fish trunks were transported up to the site (Butler and Chatters 1994). The site was excavated using $1 / 8 "$ inch mesh and provides a representative view of fish remains within the excavated contexts. In this assemblage, which provides a control for transport in archaeological contexts, cranial elements only represent $4 \%$ of the total assemblage (Butler, unpublished data), one-tenth of the percentage expected from a complete salmonid skeleton (Figure 7). This low percentage of cranial remains demonstrates that even where salmonids are known to have been taken locally, offsite processing for storage drastically reduces the occurrence of cranial remains.

In using skeletal element representations to assess fish processing, one must consider the extent variation in bone density affects preservation. For example, head parts are much less dense than trunk parts, like vertebrae (Butler 1990). Thus if a complete skeleton was subjected to destructive processes like trampling or carnivore ravaging head parts would 
be less common than vertebrae, owing to bone density. Butler and Chatters (1994)

provide a set of salmon bone density measures that can be compared with archaeological fish bone assemblages to assess the extent to which bone density is controlling body part representation. For the Housepit 7 assemblage at Keatley Creek, they demonstrated that the paucity of head remains results from heads being left at the processing site rather than on-site destruction of heads.

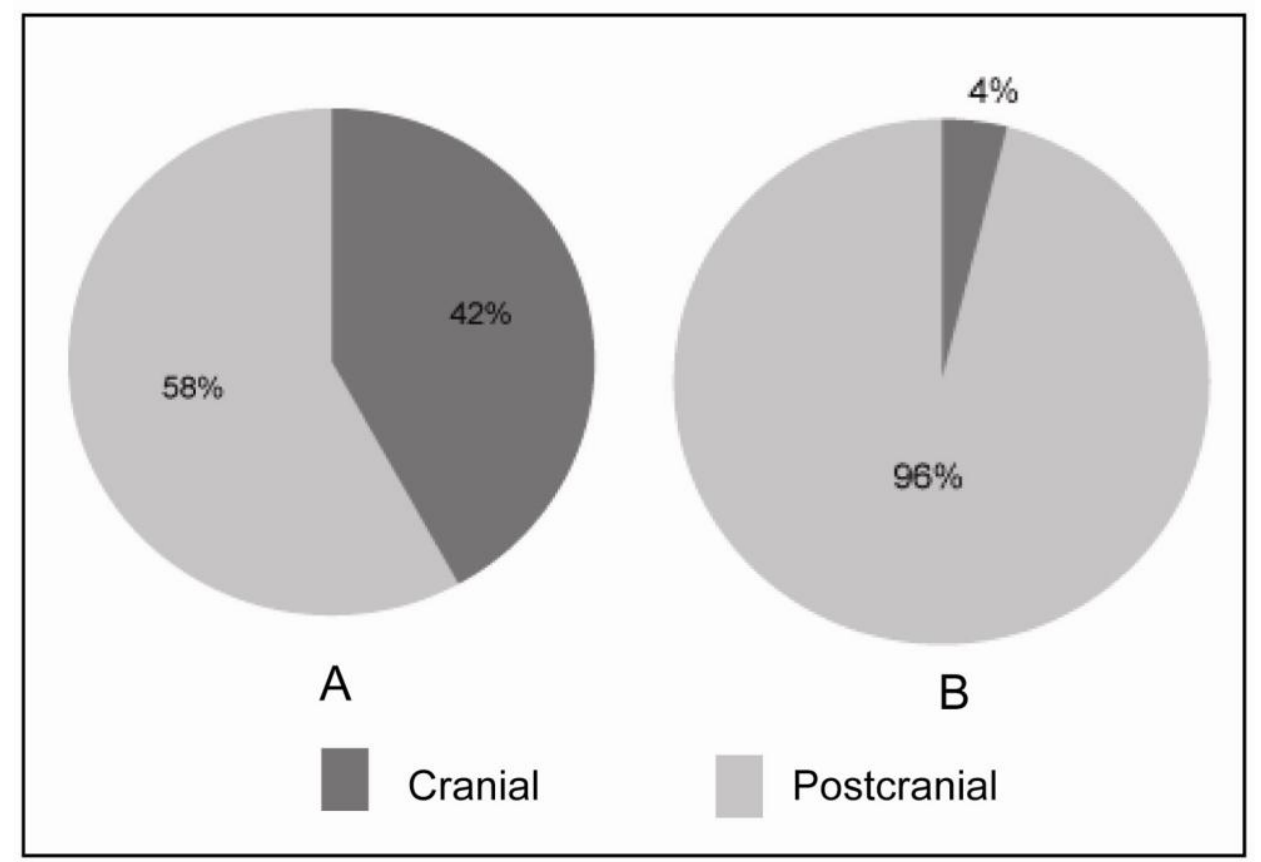

Figure 7 Percentage of cranial and postcranial remains from (A) standard salmonid skeleton recovered using 1/8" mesh; (B) salmonid remains recovered from Keatley Creek Housepit 7 (Butler, unpublished data)

\section{Evidence for Trade or Local Capture of Salmonids in Upper Klamath Assemblages}

The small samples sizes from project sites make it difficult to rigorously test ideas about trade versus local capture (Table 11), so my results are tentative. Salmonid assemblages 
from each site are treated in the aggregate with no temporal distinctions because subdividing would further decrease the sample sizes.

Examination of MAU data indicates that four of the five sites included in this study are proportionally dominated by cranial remains (Table 11). As noted in Chapter 3, curation and methodological biases exist with the assemblages from 35KL8, 35KL9-12, 35KL34. I focused on the assemblages from the 35KL677 and 35LK778 (Williamson River Bridge site and Bezuksewas Village, respectively), which have been excavated and curated in the last 20 years with some care.

Table 11 Minimum number of salmonid elements and \% MAU by site

\begin{tabular}{|c|c|c|c|c|c|c|c|c|c|c|}
\hline \multirow[t]{2}{*}{ Element } & \multicolumn{2}{|c|}{ 35KL8 } & \multicolumn{2}{|c|}{ 35KL9-12 } & \multicolumn{2}{|c|}{ 35KL34 } & \multicolumn{2}{|c|}{$\begin{array}{c}\text { Williamson R. } \\
\text { Bridge }\end{array}$} & \multicolumn{2}{|c|}{$\begin{array}{l}\text { Bezuksewas } \\
\text { Village }\end{array}$} \\
\hline & MNE & $\% \mathrm{MAU}$ & MNE & $\% \mathrm{MAU}$ & MNE & $\% \mathrm{MAU}$ & MNE & $\% \mathrm{MAU}$ & MNE & $\% \mathrm{MAU}$ \\
\hline \multicolumn{11}{|l|}{ Cranial } \\
\hline Angular/Articular & 0 & 0 & 0 & 0 & 0 & 0 & 1 & 50 & 0 & 0 \\
\hline Ceratohyal & 0 & 0 & 0 & 0 & 0 & 0 & 1 & 50 & 0 & 0 \\
\hline Dentary & 0 & 0 & 0 & 0 & 0 & 0 & 2 & 100 & 0 & 0 \\
\hline Ectopterygoid & 0 & 0 & 0 & 0 & 0 & 0 & 1 & 50 & 0 & 0 \\
\hline Hyomandibula & 0 & 0 & 0 & 0 & 0 & 0 & 1 & 50 & 0 & 0 \\
\hline Hypohyal (1 or 2) & 0 & 0 & 0 & 0 & 0 & 0 & 0 & 0 & 1 & 25 \\
\hline Prootic & 0 & 0 & 0 & 0 & 2 & 100 & 0 & 0 & 0 & 0 \\
\hline Pterotic & 0 & 0 & 0 & 0 & 1 & 50 & 0 & 0 & 0 & 0 \\
\hline Urohyal & 0 & 0 & 0 & 0 & 0 & 0 & 0 & 0 & 1 & 100 \\
\hline Vomer & 0 & 0 & 1 & 100 & 0 & 0 & 0 & 0 & 0 & 0 \\
\hline \multicolumn{11}{|l|}{ Postcranial } \\
\hline Coracoid & 0 & 0 & 0 & 0 & 0 & 0 & 1 & 50 & 0 & 0 \\
\hline Scapula & 0 & 0 & 0 & 0 & 0 & 0 & 1 & 50 & 0 & 0 \\
\hline Cleithrum & 0 & 0 & 0 & 0 & 0 & 0 & 0 & 0 & 1 & 50 \\
\hline Postcleithrum & 0 & 0 & 0 & 0 & 0 & 0 & 0 & 0 & 1 & 50 \\
\hline Vertebra (type II) & 1 & 100 & 5 & 19 & 0 & 0 & 13 & 49 & 15 & 57 \\
\hline Vertebra (type III) & 0 & 0 & 5 & 16 & 0 & 0 & 3 & 9 & 4 & 13 \\
\hline Vertebra (type IV) & 0 & 0 & 0 & 0 & 0 & 0 & 1 & 20 & 0 & 0 \\
\hline Totals & 1 & - & 11 & - & 2 & - & 25 & - & 23 & - \\
\hline
\end{tabular}


The assemblages from Williamson River Bridge and Bezuksewas Village had a larger percentage of cranial remains than the Keatley Creek assemblage discussed above (Figure 8). Yet the assemblage from Bezuksewas Village does not provide a strong case for local catch. This assemblage has only a slightly greater percentage of cranial remains than the Keatley Creek assemblage which represents offsite processing. Thus this assemblage does not support the Local Catch Hypothesis and appears to represent a transported assemblage.

The Williamson River Bridge site has many more cranial elements than either of the other examined archaeological assemblages (Figure 8). The percentage of cranial remains from this site is lower than a complete salmonid skeleton, yet it is more than six times greater than that of the Keatley Creek assemblage. These data indicate that salmonids were processed at this site and support the Local Catch Hypothesis.

Interpretations of the data from the two sites do not directly contradict one another. As noted above, simply because of the nature of human resource accumulation, task specific camps, such as fishing camps, probably are better cases on which to evaluate if fish were taken locally. While the Bezuksewas Village assemblage appears consistent with transport, salmonids represented at this site may have been caught at specialized fishing camps (e.g., the Williamson River Bridge site) along rivers in the Upper Klamath Basin and transported to the village. 


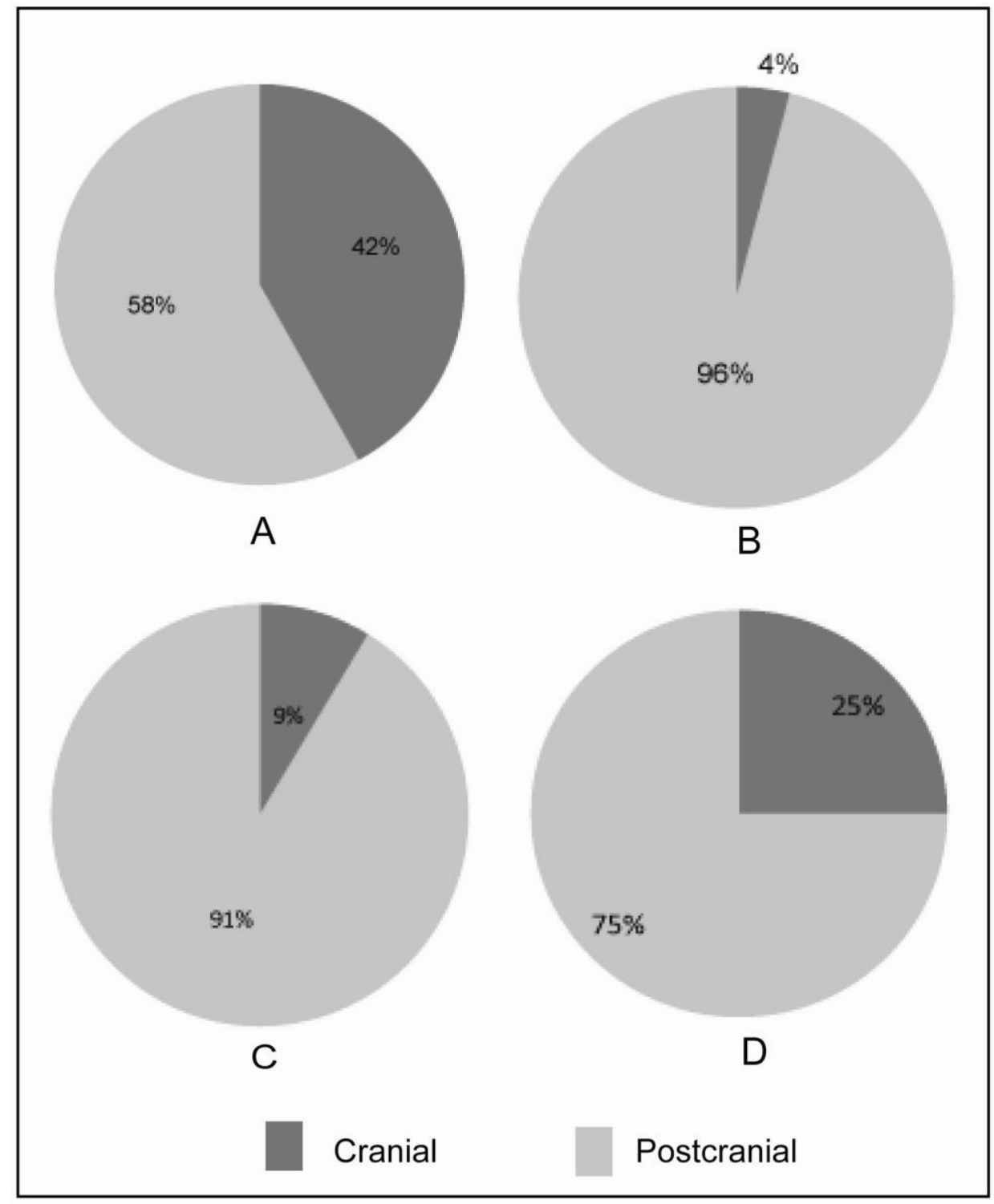

Figure 8 Comparison of salmonid remains recovered using 1/8" mesh (A) complete salmonid skeleton; (B) Keatley Creek Housepit 7; (C) Bezuksewas Village; (D) Williamson River Bridge

This conclusion must be considered tentative because of the limited sample size and the difficulty of statistically evaluating whether other processes may have created the observed assemblage structure, such as bone density. 
By examining the MAU data a slightly different picture arises (Table 11). As noted above, four of the five sites included in this study are dominated by cranial elements. These data indicate that trunks are missing from these assemblages (Table 11). As note most cranial elements are much less dense than trunk elements, especially vertebrae (Butler and Chatters 1994). Bone density has traditionally been measured as grams per cubic centimeter $\left(\mathrm{g} / \mathrm{cm}^{3}\right)$ and, as stated above, provides a proxy for preservation potential. Very fragile cranial elements were recovered from most sites in this study, including three dentaries $\left(0.19 \mathrm{~g} / \mathrm{cm}^{3}\right)$ and a ceratohyal $\left(0.06 \mathrm{~g} / \mathrm{cm}^{3}\right)$ from the Williamson River Bridge site, which are much less dense than the densest trunk element (type III vertebra $\left.\left[0.34 \mathrm{~g} / \mathrm{cm}^{3}\right]\right)$.

The proportional domination (\%MAU) of less dense cranial elements is expected in situations where fish are taken locally. In situations where trade and/or transport are expected, assemblages should be dominated by trunk elements. While there is some possibility for cranial elements in village settings, only the local catch scenario is expected to produce assemblages proportionally dominated by cranial remains. The fact that cranial elements, which are fragile (i.e., low density) proportionally dominate these assemblages supports the Local Catch Hypothesis. That these small assemblages are dominated by what should be rare classes of data (i.e., fragile cranial elements) further supports this hypothesis. 
Comparison of percentages of raw counts and MAUs provide slightly different pictures of salmonid procurement in the Upper Klamath Basin archaeological assemblages. However, the proportional domination of cranial elements and the large percentage of cranial elements from Williamson River Bridge together suggest that these bones represent salmonids that were taken locally from rivers above Upper Klamath Lake. 


\section{Chapter 7: Conclusions}

The goal of this study was to establish the native status of anadromous salmonids in the Upper Klamath Basin prior to the development of dams along the mainstem of the Klamath River. As discussed earlier, the presence of these fish within the region, especially above Upper Klamath Lake, has been the subject of debate.

This study examined fish remains from five archaeological sites above Upper Klamath Lake and identified salmonid remains within each of the assemblages (Table 11). A total of 5,853 specimens were identified at least to the order taxonomic level. Seventy-five $(1.3 \%)$ of the total identified specimens were salmonids. Analysis of mtDNA from 31 specimens provided positive species level identifications (25 O. mykiss, 6 O. tshawytscha). Because O. mykiss has two forms, one anadromous (steelhead) and one resident freshwater (redband trout) which are indistinguishable using the mtDNA method employed here, Sr:Ca was measured to characterize migratory pattern. Strontium is present in higher concentrations in marine environments and is incorporated into tissue at a greater rate in saline environments than in freshwater ones. Twenty-six archaeological specimens were subjected to LA-ICP-MS to determine Sr:Ca values. Twenty-three specimens were determined to be anadromous, and three were determined to be freshwater resident. Not every specimen identified genetically was also measured for Sr:Ca. Each of the specimens identified as Chinook yielded Sr:Ca values which indicated anadromy. Sixteen specimens identified as $O$. mykiss were determined to have been 
anadromous while two $O$. mykiss specimens were freshwater resident forms. Combined, these data indicate the presence of fish remains from anadromous salmon and trout in precontact archaeological sites above Upper Klamath Lake.

Very few salmonid remains were discovered during the course of this analysis. Only 81 salmonid specimens were observed out of a total of over 5,800 identified fish remains. As discussed, this low frequency of salmonid remains may be a result of cultural and natural factors including density related attrition, season of site use and archaeological sampling.

Two hypotheses for the introduction of fish remains into the Upper Klamath Basin archaeological sites were evaluated, the Local Catch and Trade/Transport Hypotheses. Ethnographic data and archaeological interpretations were used to develop expectations for the hypotheses for introduction methods. Assemblages resulting from trade/transport should contain few, if any, head parts because these are often removed during processing and are not transported along with trunks. Sites where fish were taken locally should contain head parts in greater proportion than trunk parts.

Additionally, cranial elements are not very dense and are so fragile they are often destroyed by natural, post-depositional processes. Thus, these elements are less likely to be represented in archaeological assemblages than denser trunk elements for preservation reasons alone. 
The small sample sizes from the five sites precludes rigorous evaluation of ideas about butchery, processing and density-mediated destruction. However, four of the five archaeological assemblages from the Upper Klamath Basin were proportionally dominated (i.e., MAU) by cranial elements. This fact, along with the lower likelihood that head parts would survive post-depositional forces, supports the Local Catch Hypothesis and indicates that these fish were taken from rivers above Upper Klamath Lake.

From this study and ethnographic work in the area it is clear that there is a long history of fish use by peoples in the region and anadromous salmon were certainly part of that picture. Using these data it is difficult to determine times of relative abundance versus paucity of salmon, partially because of the difficulties inherent in archaeological data but also in part as a result of bioturbation, poor curation of assemblages and excavation methods which are now found to be lacking. Controlled excavation of well-stratified, relatively undisturbed sites may provide better insight into issues of temporal changes in relative abundance and use of salmonids in the area. These projects should be targeted at sites that were ethnographically used as salmon fishing sites such as lobŏ'kstsŏki, a location above Upper Klamath Lake that Spier (1930:14) notes has “...a dam for salmon..." or other sites which may not be part of the written record but exist in oral traditions of the peoples of the Klamath Basin. 
Additionally, further geochemical studies would provide a more rigorous test of the Trade versus Local Catch hypotheses. Trace element and isotopic data, $\mathrm{Sr}^{87} / \mathrm{Sr}^{86}$ may be particularly instructive in attempting to characterize watersheds from which these salmon came. Archaeological applications of these analyses (e.g., Dufour et al. 2006) have demonstrated that they have some potential to address questions of origin but complex chemical processes may introduce unknown levels of error in these data.

The contentious nature of salmonid restoration and dam removal efforts within the Klamath Basin makes dissemination of information like this study critical because it provides a tangible link to the past for parts of the public who may not otherwise have a connection. Across the United States archaeology has been a "pastime" of many families through both sightseeing and "pot hunting". Data such as these provide an ideal opportunity to reach out and relate to the public on many levels. With the proper approach, the link between and value of endeavors like preservation and restoration can be clearly demonstrated.

This study has demonstrated ways in which archaeological data can be used to address current issues in wildlife management and restoration. The data presented here have implications for the larger wildlife management and restoration issues in the Klamath Basin as a whole. With the date for the Secretary of the Interior's record of decision on dam removal along the Klamath River impending, these data are particularly important for demonstrating the native status of anadromous salmonids above Upper Klamath Lake. 
Finally, this study provides another example of how archaeological data can be used to address questions that are relevant to the modern world especially in the arenas of conservation and restoration. The time depth and independently verifiable nature of archaeological data provide an ideal data source for wildlife managers and policy makers alike to draw upon in situations where other types of documentation are limited and/or severely biased. 


\section{References Cited}

Aikens, C. M. and R. Minor

1978 Obsidian Hydration Dates for Klamath Prehistory. Tebiwa 11.

Bacon, Charles R.,

1983 Eruptive History of Mount Mazama and Crater Lake Caldera, Cascade Range,

U.S.A.: Journal of Volcanology and Geothermal Research, v.18, p.57-

Bath, G., S. R. Thorrold, C. M. Jones, S. E. Campana, J. W. McLaren and J. W. H. Lam 2000 Strontium and barium uptake in aragonitic otoliths of marine fish. Geochimica et Cosmochimica Acta 64(10):1705-1714.

Barrett, S. A.

1910 The Material Culture of the Klamath Lake and Modoc Indians of Northeastern California and Southern Oregon. University of California Publications in American Archaeology and Ethnology 5.

Binford, L. R.

1980 Willow Smoke and Dogs' Tails: Hunter-Gatherer Settlement Systems and Archaeological Site Formation. American Antiquity 45(1):4-20.

Braje, T. J.

2010 Modern Oceans, Ancient Sites: Archaeology and Marine Conservation on San Miguel Island, California. University of Utah Press, Salt Lake City.

Broughton, J.

1994 Declines in Mammalian Foraging Efficiency during the Late Holocene, San Francisco Bay, California. Journal of Anthropological Archaeology 13:371-401.

1997 Widening diet breadth, declining foraging efficiency, and prehistoric harvest pressure: icthyofaunal evidence from the Emeryville Shellmound, California. Antiquity 71:845-862.

Bourdeau, A.

2004 "Following in Luther's Footsteps": Results from Surveys on the Harris Property for the Sprague River S'Ocholis Project, Klamath County, Oregon. U.S. Fish and Wildlife Service.

Boyd, R.

1996 People of the Dalles: The Indians of Wascopam Mission. University of Nebraska Press, Lincoln. 
Butler, V. L.

1990 Distinguishing Natural from Cultural Salmonid Deposits in the Pacific Northwest of North America. Unpublished Ph.D. Dissertation, University of Washington.

1993 Natural Versus Cultural Salmonid Remains: Origin of The Dalles Roadcut Bones, Columbia River, Oregon, USA. Journal of Archaeological Science 20:1-24.

1996 Tui Chub Taphonomy and the Importance of Marsh Resources in the Western Great Basin of North America. American Antiquity 61(4):699-717.

Butler, V. L., N. Misarti, D.Y. Yang, C.F. Speller, T.J. Connolly, D.L. Jenkins

2010 Evidence for Anadromous Salmonids in the Upper Klamath Basin Based on DNA and Geochemistry Analysis of Archaeological Remains. Paper Presented at the 2009 Gilbert Society Meeting.

Butler, V. L. and N. J. Bowers

1998 Ancient DNA from Salmon Bone: a Preliminary Study. Ancient Biomolecules 2:17-26.

Butler, V. L. and S. K. Campbell

2004 Resource Intensification and Resource Depression in the Pacific Northwest of North America: A Zooarchaeological Review. Journal of World Prehistory 18(4):327-405.

Butler, V. L. and J. C. Chatters

1994 The Role of Bone Density in Structuring Prehistoric Salmon Bone Assemblages. Journal of Archaeological Science 21:413-424.

Butler, V. L. and M. G. Delacorte

2004 Doing Zooarchaeology as if it Mattered: Use of Faunal Data to Address Current Issues in Fish Conservation Biology in Owens Valley, California. In Zooarchaeology and Conservation Biology, edited by R. L. Lyman and K. P. Cannon, pp. 25-44. University of Utah Press, Salt Lake City.

Campana, S. E.

1999 Chemistry and composition in fish otoliths: pathways, mechanisms and applications. Marine Ecology Progress Series 188:263-297.

Cannon, A. and D. Y. Yang

2006 Early Storage and Sedentism on the Pacific Northwest Coast: Ancient DNA analysis of Salmon Remains from Namu, British Columbia. American Antiquity 71(1):123-140. 
Cannon, K. P. and M. B. Cannon

2004 Zooarchaeology and Wildlife Management in the Greater Yellowstone Ecosystem. In Zooarchaeology and Conservation Biology, edited by R. L. Lyman and K. P. Cannon. University of Utah Press, Salt Lake City.

Casteel, R. W.

1976 Fish Remains in Archaeology and Paleo-environmental Studies. Academic Press, London.

1982 Appendix 2: Fish Remains from Kettle Falls, Washington. In Kettle Falls: 1971 and 1974 Salvage Archaeology at Lake Roosevelt, edited by D. H. Chance and J. V. Chance. University of Idaho Anthropological Research Manuscipt Series No. 69. University of Idaho, Moscow. Chapman, D. W.

Chapman, D. W.

1981 Pristine Production of Anadromous Salmonids - Klamath River: FINAL REPORT. Bureau of Indian Affairs: U.S. Department of the Interior, Portland, OR.

Cheatham, R. D.

1990 Archaeological Investigations at Collier State Park. CAHO 15(2):7-11.

1991 Archaeological Investigations at the Williamson River Bride Site (35KL677): A Riverside Fishing Camp in Klamath County, Oregon. Oregon State Museum of Anthropology. Submitted to Oregon Department of Transportation.

Cheatham, R. D., M. Robinson, T. J. Connolly, G. L. Tasa, V. J. Singer, D. E. Freidel, M. C. Darby, N. A. Stenholm and C. Allen

1995 Archaeological Investigations at the Bezuksewas Village Site (35KL778),

Klamath County, Oregon. Oregon State Museum of Anthropology, University of Oregon.

Cressman, L.

1948 Klamath Indian Archaeology Prelimary. Northwest Science 22:83- 88.

1956 Klamath Prehistory: The Prehistory of the Culture of the Klamath Lake Area, Oregon. Transactions of the American Philosophical Society, New Series 46.

Cressman, L. S., D. L. Cole, W. A. Davis, T. M. Newman, and D. J. Scheans

1960 Cultural Sequences at the Dalles, Oregon: A Contribution to Pacific Northwest Prehistory. Transactions of the American Philosophical Society 50(10):1-108.

Deur, D.

2003 Traditional Cultural Properties and Sensitive Resource Study; Klamath Tribes. Unpublished FERC Relicensing Document.

Drennan, R. D.

1996 Statistics for Archaeologists: A Commonsense Approach. Plenum Press, NY 
Dufour, E., Chris Holmden, Wim Van Neer, Antoine Zazzo, William P. Patterson, Patrick Degryse, Eddy Keppens

2006 Oxygen and strontium isotopes as provenance indicators of fish at archaeological sites: the case study of Sagalassos, SW Turkey. Journal of Archaeological Science:1-14.

Erlandson, J. M. and T. C. Rick

2008 Archaeology, Marine Ecology and Human Impacts on Marine Environments. In Human Impacts on Ancient Marine Ecosystems: A Global Perspective, edited by T. C. Rick and J. M. Erlandson, pp. 1-19. University of California Press, Berkeley.

Etnier, M. A.

2004 The Potential of Zooarchaeological Data to Guide Pinniped Management Decisions in the Eastern North Pacific. In Zooarchaeology and Conservation Biology, edited by R. L. Lyman and K. P. Cannon, pp. 88-102. University of Utah Press, Salt Lake City.

Evans, N. H.

1990 Traditions of Sucker Exploitation in the Pit River System: An Ajumawi Example. Journal of California and Great Basin Anthropology 12(1):48-59.

Evermann, B. W. and S. E. Meek

1897 Salmon Investigations in the Columbia River Basin and elsewhere on the Pacific Coast in 1896. Bulletin of the United States Fish Commission XVII: 15-84

Fladmark, K. R.

1975 A paleoecological model for Northwest Coast prehistory. Mercury Series Paper 43. Archaeological Survey of Canada.

Fortune, J. D., A. R. Gerlach, and C. J. Hanel

1966 A study to determine the feasibility of establishing salmon and steelhead in the Upper Klamath Basin: Oregon State Game Commission and Pacific Power and Light Company. Portland, OR

Fowler, C. S.

1986 Subsistence. In Great Basin, edited by W. L. D'Azevedo, pp. 64-97. Handbook of North American Indians, vol. 11, W. C. Sturtevant, general editor. Smithsonian Institution, Washington, D.C.

Fowler, C. S. and J. E. Bath

1981 Pyramid Lake Northern Paiute Fishing: The Ethnographic Record. Journal of California and Great Basin Anthropology 3(2):176-186. 
Gatschet, A. S.

1890a Ethnographic Sketch of the Klamath Indians of Southwestern Oregon.

Contributions to North American Ethnology II part I. Department of the Interior, Washington, D.C.

1890b Dictionary of the Klamath Language. Contributions to North American Ethnology II part II. Department of the Interior, Washington D.C.

Gibson-Reinemer, D. K., P. J. M. Brett M. Johnson, A. E. K. Dana L. Winkelman and J. D. Woodhead

2009 Elemental signatures in the otoliths of hatchery rainbow trout (Oncorhynchus mykiss); distinctiveness and utility for detecting origins and movement. Canadian Journal of Fisheries and Aquatic Science 66:512-524.

Gilbert, C. H.

1897 Fishes of the Klamath Basin. Bulletin of the United States Fish Commission XVII:1-13.

Gorschkov, S.A., Y.A. Dorofeyeva, V.A. Klyukanov, N.I. Kulikova

1979 Osteological characteristics of the Pacific salmons in the genus Oncorhynchus. Journal of Ichthyology 19:1-19.

Grayson, D. K.

1984 Quantitative Zooarchaeology. Academic Press, Washington D.C.

2001 The Archaeological Record of Human Impacts on Animal Populations. Journal of World Prehistory 15(1):1-68.

Grayson, D. K. and D. B. Madsen

2000 Biogeographic Implications of Recent Low-Elevation Recolonization by Neotoma cinerea in the Great Basin. Journal of Mammalogy 81(4):1100-1105.

Groot, G. and L. M. (editors)

1991 Pacific Salmon: Life Histories. University of British Columbia Press, Vancouver.

Gunatilaka, A.

1981 Biogeochemistry of Strontium. In Handbook of Stable Strontium, edited by S. C. Skoryna, pp. 644. Plenum, New York.

Hamilton, J. B., G. L. Curtis, S. M. Snedaker and D. K. White

2005 Distribution of Anadramous Fishes in the Upper Klamath River Watershed Prior to Hydropower Dams- A synthesis of the Historical Evidence. Fisheries 30(4):1020. 
Hayden, B., (editor)

1993 A Complex Culture of the British Columbia Plateau: Traditional Stl'a 'l'imx Resource Use. UBC Press. Vancouver

Houk, R. S.

1985 Mass Spectrometry of Inductively Coupled Plasmas. Analytical Chemistry 58(1):97-105.

Huntington, C. W.

2004 Technical Memorandum: Preliminary estimates of the recent and historic potential for anadromous fish production above Iron Gate Dam. Clearwater BioStudies, Inc., Canby.

Ingram, B. L. and P. K. Weber

1999 Salmon origin in California's Sacramento-San Joaquin river system as determined by otolith strontium isotopic composistion. Geology 27(9):851-854.

Kalish, J. M.

1990 Use of Otolith Microchemistry to Distinguish the Progeny of Sympatric Anadrmous and Non-anadrmous Salmonids. Fishery Bulletin 88(4):657-666.

Kemp, B. M., R. S. Malhi, J. McDonough, D. A. Bolnick, J. A. Eshleman, O. Rickards, C. Martinez-Labarga, J. R. Johnson, J. G. Lorenz, E. J. Dixon, T. E. Fifield, T. H. Heaton, R. Worl and D. G. Smith

2007 Genetic Analysis of Early Holocene Skeletal Remains from Alaska and its Implications for the Settlement of the Americas. American Journal of Physical Anthropology 132:605-621.

Kitchen, A., M. M. Miyamoto and C. J. Mulligan

2008 A Three-Stage Colonization Model for the Peopling of the Americas. PLoS ONE $3(2): 1-7$.

Kroeber, A. L.

1925 Handbook of the Indians of California. Bureau of American Ethnology Bulletin

No. $\quad$ 78. Smithsonian Institution, Washington D.C.

Lane and Lane

1981 The Copco Dams and the Fisheries of the Klamath Tribe. Prepared for The Bureau of Indian Affairs, U.S. Department of the Interior, Portland, OR.

Lauwerier, R.C.G.M., I. Plug, editors.

2004 The future from the past: archaeozoology in wildlife conservation and heritage management. Oxford: Oxbow Books 
List, R., G. Ceballos, C. Curtin, P. J. P. Gogan, J. Pacheco and J. Truett

2007 Historic Distribution and Challenges to Bison Recovery in the Northern

Chihuahuan Desert. Conservation Biology 21(6):1487-1494.

Lyman, R. L.

1984 Bone Density and Differential Survivorship of Fossil Classes. Journal of Anthropological Archaeology 3:259-299.

1994 Vertebrate Taphonomy. Cambridge Manuals in Archaeology. Cambridge University Press, Cambridge.

1995 Determining When Rare (Zoo-)archaeological Phenomena Are Truly Absent. Journal of Archaeological Method and Theory 2(4):369-424.

1996 Applied zooarchaeology: the relevance of faunal analysis to wildlife management. World Archaeology 28(1):110-125.

2006 Paleozoology in the Service of Conservation Biology. Evolutionary Anthropology 15:11-19.

Lyman, R. L., J. A. Harpole, C. Darwent and R. Church

2002 Prehistoric Occurence of Pinnipeds in the Lower Columbia. Northwestern Naturalist 83:1-16.

Lyman, R. L. and K. P. Cannon

2004 Applied Zooarchaeology, Because It Matters. In Zooarchaeology and Conservation Biology, edited by R. L. Lyman and K. P. Cannon. University of Utah Press, Salt Lake City.

Miller, J.A.

2009. The effects of temperature and water concentration on the otolith incorporation of barium and manganese in black rockfish (Sebastes melanops Girard). Journal of Fish Biology, 75(1): 39-60.

Miller, J.A., Gray, A., and Merz, J. 2010. Quantifying the contribution of juvenile migratory phenotypes in a population of Chinook salmon (Oncorhynchus tshawytscha). Marine Ecology Progress Series 408: $227-240$.

Miller, J. A., V.L. Butler, C.A. Simenstad, D.H. Backus, A.J.R. Kent

2011 Life history variation in upper Columbia River Chinook salmon (Oncorhynchus tshawytscha): a comparison using modern and $~ 500$-yearl-old archaeological otoliths. Canadian Journal of Fisheries and Aquatic Science 68:603-617

Musil, R. R.

1987 Archaeological Investigations at Beatty Curve. Oregon State Museum of Anthropology. 
Markle, D. F. and M. S. Cooperman

2001 Relationships between Lost River and Shortnose sucker Biology and Management of Upper Klamath Lake. In Water Allocation in the Klamath Reclamation Project, 2001: An Assessment of Natural Resource, Economic, Social and Institutional Issues with a Focus on the Upper Klamath Basin, pp. 93-117. Oregon State University, Corvallis.

Moyle, P. B.

2002 Inland Fishes of California. University of California Press, Berkeley.

National Research Council (NRC)

2004 Endangered and Threatened Fishes of the Klamath River Basin: Causes of Decline and Strategies for Recovery. The National Academic Press, Washington, D.C.

2008 Hydrology, Ecology, and Fishes of the Klamath River Basin. The National Academic Press, Washington, D.C.

Newmaster, S. G., R. Subramanyam, R. F. Ivanhoff and N. C. Balasubramaniam 2006 Mechanisms of ethnobiological classifications. Ethnobotany 18:4-26.

Pääbo, S., H. Poinar, D. Serre, V. Jaenicke-Despres, J. Hebler, N. Rohland, M. Kuch, J. Krause, L. Vigilant and M. Hofreiter

2004 Genetic Analyses from Ancient DNA. Annual Review of Genetics 38:645-679.

PacifiCorp

2009a Press Release: Klamath Dam Agreement Unveiled. Electronic Document,http://www.pacificorp.com/Press_Release/Press_Release9173 3.html, accessed November 15, 2009.

2009b Summary Draft Klamath Hydroelectric Settlement Agreement, pp. 1-6.

Peacock, E., W. R. Haag and M. L. Warren Jr.

2005 Prehistoric Decline in Freshwater Mussels Coincident with the Advent of Maize Agriculture. Conservation Biology 19(2):547-551.

Pollard, M., C. Batt, B. Stern and S. M. Young

2007 Analytical Chemistry in Archaeology. Cambridge Manuals in Archaeology. Cambridge University Press, Cambridge.

Quinn, T. P.

2005 The Behavior and Ecology of Pacific Salmon and Trout. University of Washington Press, Seattle. 
Resano, M., E. Garcia-Ruiz and F. Vanhaecke

2010 Laser ablation-inductively couple plasma mass spectrometry in archaeometric research. Mass Spectrometry Reviews 29:55-79.

Richards, M. B., K. Smalley, B. C. Sykes and R. E. M. Hodges

1993 Archaeology and Genetics: Analysing DNA from Skeletal Remains. World Archaeology 25:18-28.

Richards, M. B., B. C. Sykes and R. E. M. Hodges

1995 Authenticating DNA Extracted from Ancient Skeletal Remains. Journal of Archaeological Science 22:291-299.

Robinson, B. S., G. L. Jacobson, M. G. Yates, A. E. Spiess and E. R. Cowie 2009 Atlantic salmon, archaeology and climate change in New England. Journal of Archaeological Science 36:2184-2191.

Romanoff, S.

1993 Fraser Lillooet salmon fishing. In B. Hayden (editor) A Complex Culture of the British Columbia Plateau: Traditional Stl'a'l'imx Resource Use. pp. 222-265 UBC Press, Vancouver.

Schalk, R. F.

1977 The Structure of an Andromous Fish Resource. In For Theory Building in Archaeology, edited by L. R. Binford, pp. 207-249. Academic Press, New York.

Schurr, T. G.

2004 The Peopling of the New World: Perspectives from Molecular Anthropology. Annual Review of Anthropology 33:551-583.

Snyder, J. O.

1931 Salmon of the Klamath River, California. Fish Bulletin No. 34. California State Printing Office.

Speakman, R. J. and H. Neff (editors)

2005 Laser Ablation-ICP-MS in Archaeological Research. University of New Mexico Press, Albuquerque.

Speller, C. F., D. Y. Yang and B. Hayden

2005 Ancient DNA investigation of prehistoric salmon resoure utilization at Keatley Creek, British Columbia, Canada. Journal of Archaeological Science 32:13781389. 
Spier, L.

1930 Klamath Ethnography. University of California Publications in American Archaeology and Ethnology 30.

Stein, J. K., J. N. Deo and L. S. Phillips

2003 Big Sites-Short Time: Accumulation Rates in Archaeological Sites. Journal of Archaeological Science 30:297-316.

Sylvester, P. (editor)

2008 Laser Ablation ICP-MS in the Earth Sciences: Current Practices and Outstanding Issues. 40. Mineralogical Association of Canada, Vancouver.

Thomas, D.H. and D. Mayer

1983 Behavioral faunal analysis of selected horizons. In D.H. Thomas (ed.) The archaeology of Monitor Valley 2: Gatecliff Shelter, pp. 353-391American Museum of Natural History Anthropological Papers 59.

Trigger, B.

1989 A History of Archaeological Thought. Second Edition ed. Cambridge University Press, Cambridge.

United States vs California Oregon Power Company (COPCO)

1942 Proposed Action for Injunction and Damages, Statement of Facts. Document on file at the National Archives Pacific AK region.

U.S. Fish and Wildlife

2010 The Importance of the Klamath River to Anadromous Fish. Electronic document http://www.fws.gov/yreka/HydroImportance.html accessed March 12, 2011.

Whyte, T.R.

2004 Zooarchaeological Evidence of the Native Icthyofauna of the Roanoke River of North Carolina and Virginia. In Zooarchaeology and Conservation Biology, edited by R. L. Lyman and K. P. Cannon, pp. 193-200. University of Utah Press, Salt Lake City.

Willerslev, E. and A. Cooper

2005 Ancient DNA. Proceedings of the Royal Society B 272:3-16.

Williams, J. E., Bowman, D. B., et al.

1985 Endangered aquatic ecosystems in North American deserts with a list of vanishing fishes of the region. Journal of the Arizona-Nevada Academy of Sciences. 20:1-62. 
Yang, D. Y., A. Cannon and S. R. Saunders

2004 DNA species identification of archaeological salmon bone from the Pacific Northwest Coast of North America. Journal of Archaeological Science 31:619631.

Yang, D. Y. and C. F. Speller

2006 Co-amplification of cytochrome $b$ and D-loop mtDNA fragments for the identification of degraded DNA samples. Molecular Ecology Notes 6:605-608.

Yang, D. Y. and K. Watt

2005 Contamination controls when preparing archaeological remains for ancient DNA analysis. Journal of Archaeological Science 32:331-336.

Zazzo, A., G. R. Smith, W. P. Patterson and E. Dufour

2006 Life history reconstruction of modern and fossil sockeye salmon (Oncorhynchus nerka) by oxygen isotopic analysis of otoliths, vertebrae, and teeth: Implication for paleoenvironmental reconstructions. Earth and Planetary Science Letters 249:200-215.

Zimmerman, C. E.

2005 Relationship of otolith strontium-to-calcium ratios and salinity: experimental validation for juvenile salmonids. Canadian Journal of Fisheries and Aquatic Science 62:88-97.

Zimmerman, C. E. and G. H. Reeves

2002 Identification of Steelhead and Resident Rainbow Trout Progeny in the Deschutes River, Oregon, Revealed with Otolith Microchemistry. Transactions of the American Fisheries Society 131:989-993. 
Appendix A: Archaeological Salmonid Remains Catalog 


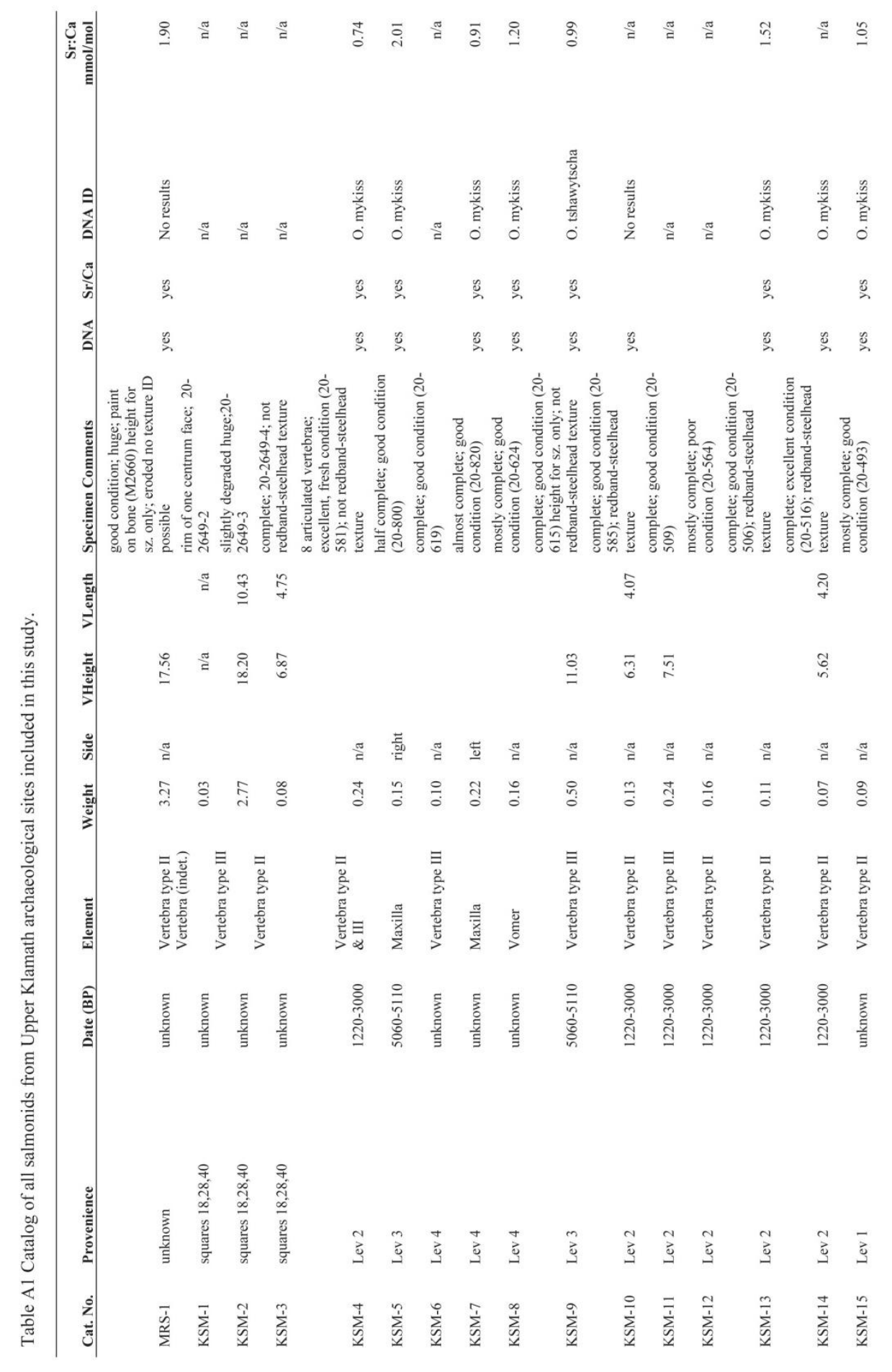




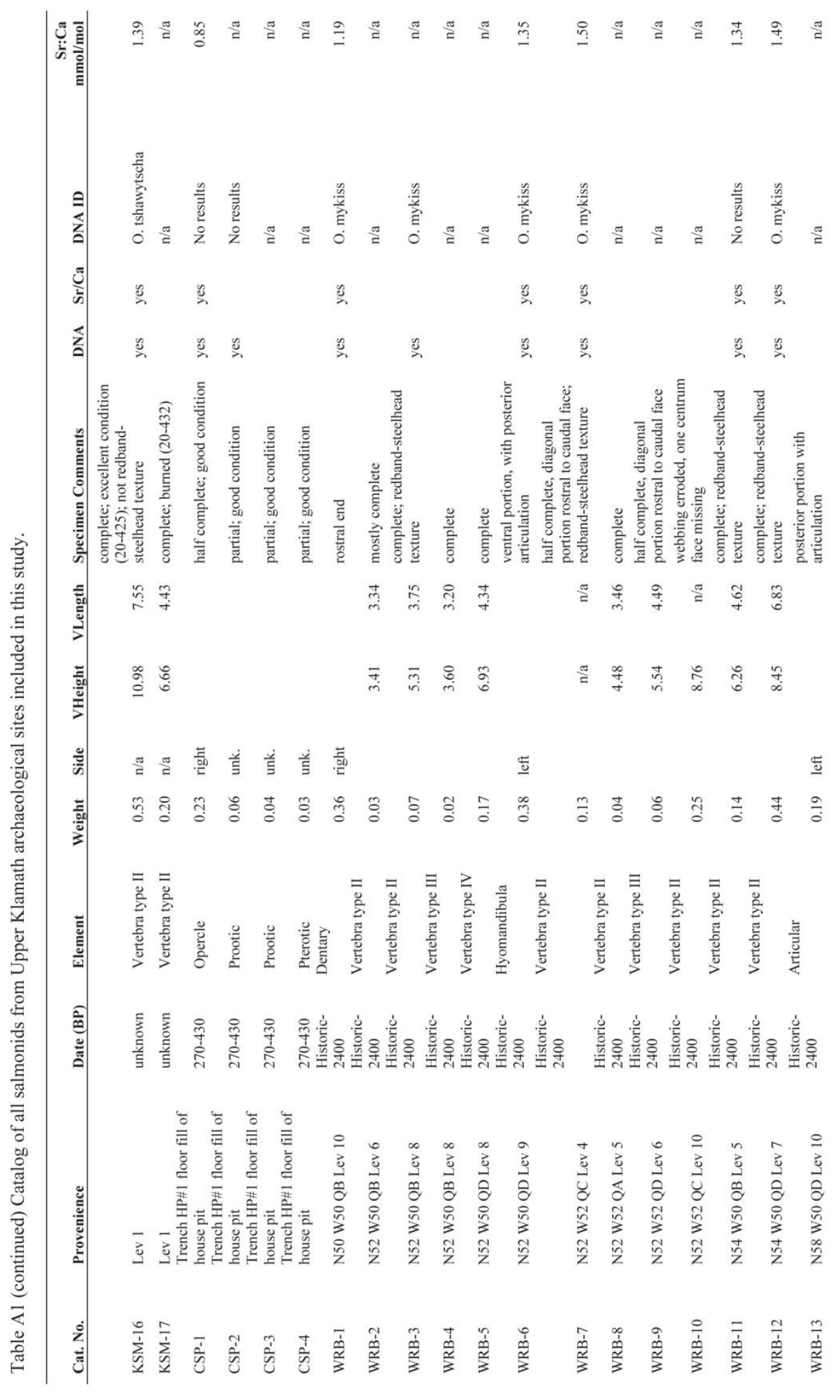




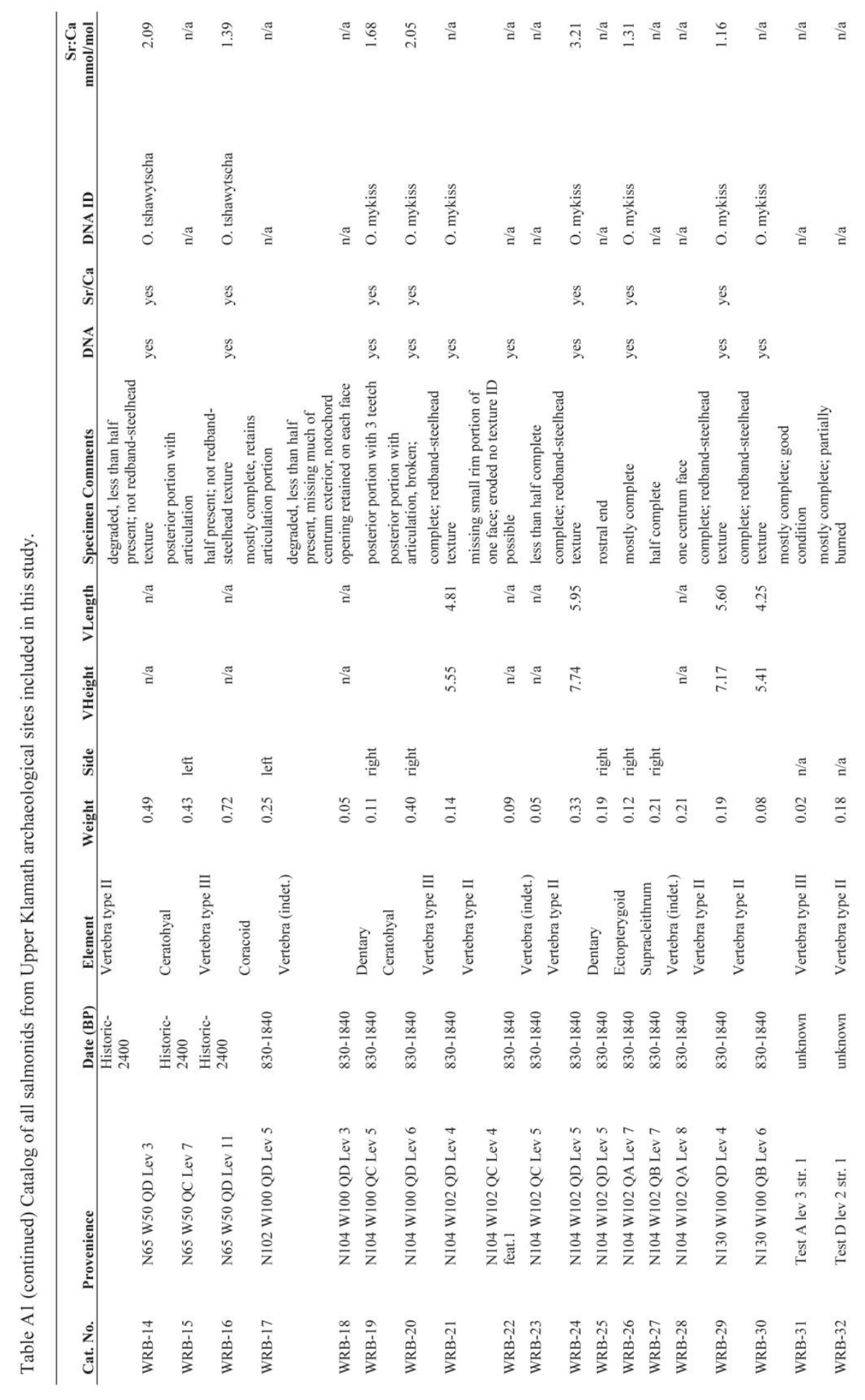




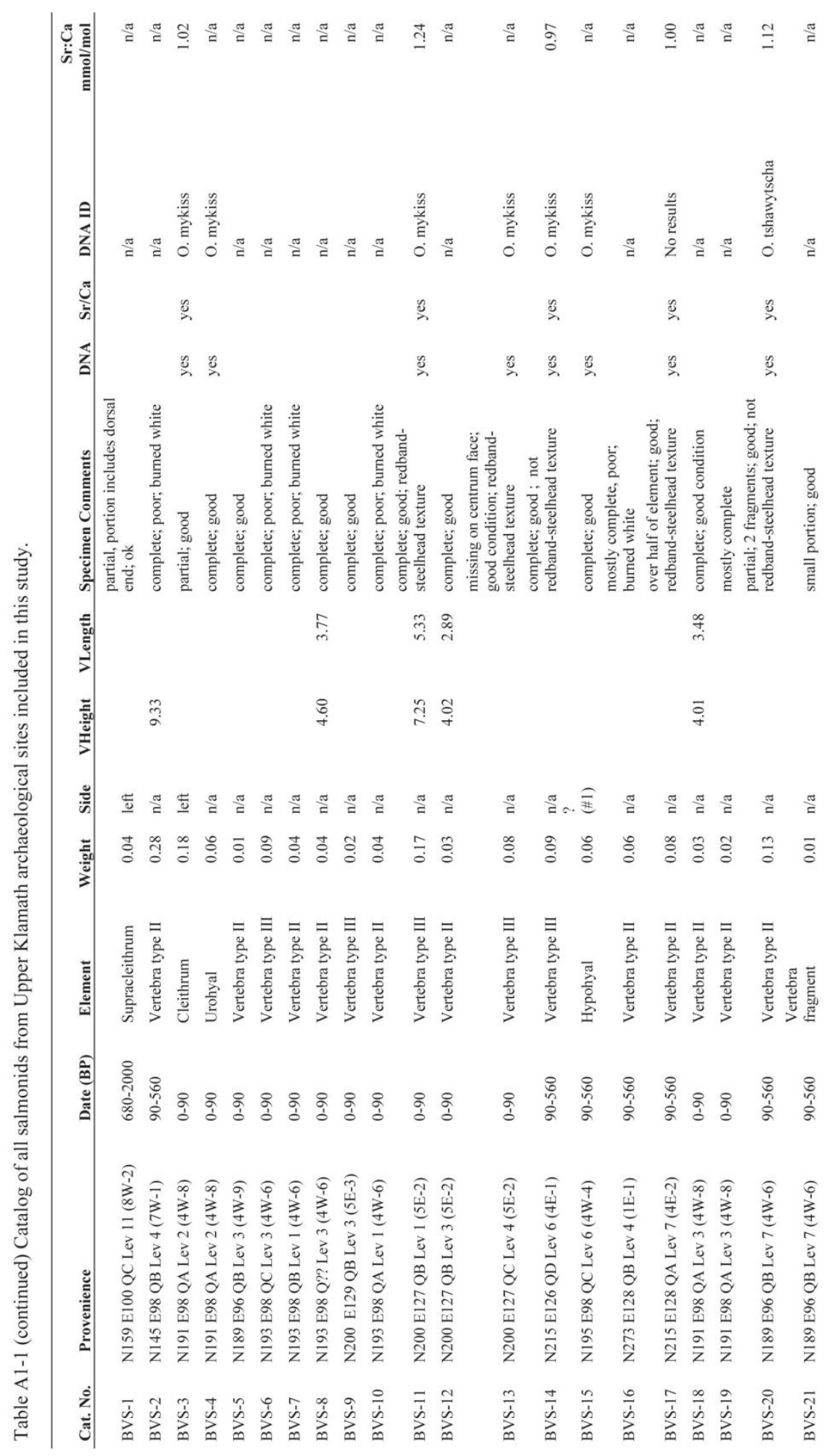




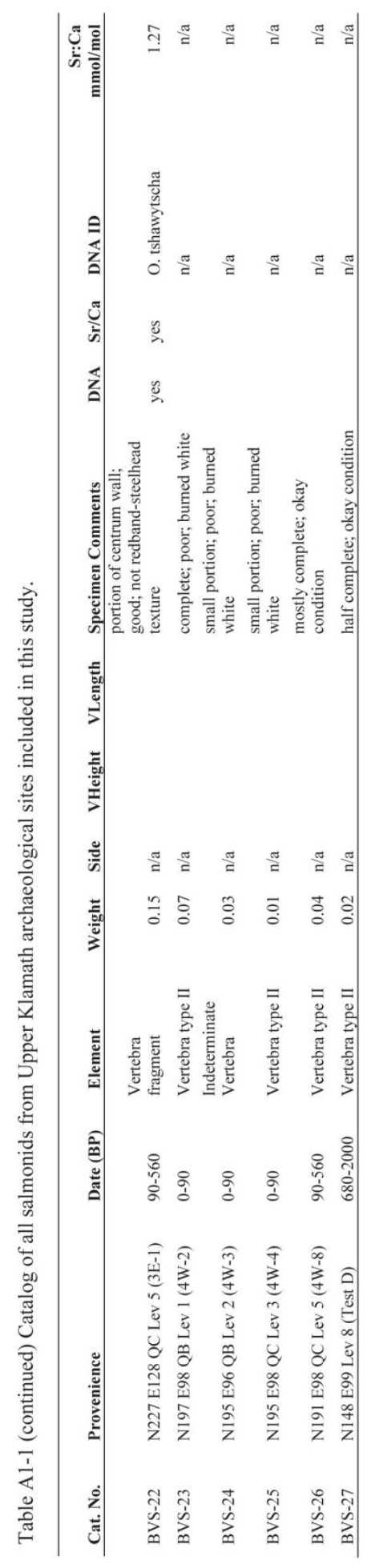


Appendix B: Simon Fraser University mtDNA Technical Report 


\title{
aDNA LAB REPORT (2010-03)
}

\author{
Ancient DNA Laboratory \\ Simon Fraser University
}

Project Conducted by Camilla Speller

Project Supervised by Dongya Yang

October 2010 


\section{SUMMARY}

Ancient DNA analysis was conducted on 52 archaeological salmonid remains recovered from six archaeological sites within the Klamath Basin, Oregon. Mitochondrial DNA (mtDNA) sequences were obtained from 45 of the samples. Based on the obtained cytochrome $b$ and control-region (d-loop) sequences, 37 bones were identified as Oncorhynchus mykiss (Rainbow trout) and eight as $O$. tshawytscha (Chinook salmon).

\section{ORIGIN}

The archaeological salmonid remains were recovered from six archaeological sites within the Klamath Basin, Oregon: Beatty Curve (35KL95), Bezuksewas Village (35KL778), Collier State Park (35KL34), Medicine Rock Cave (35KL8), Kawumkan Springs Midden (35KL9-12), and Williamson River Bridge (35KL677).

\section{DATE}

The samples were provided to Dr. Dongya Yang in September 2010. Ancient DNA analyses were conducted in September and October 2010.

\section{CONTACT}

Dr. Virginia Butler, Department of Anthropology

Portland State University

Portland, Oregon, 97207-0751

Tel: 503-725-3303, Fax: 503-725-3905

Email: butlerv@pdx.edu . 


\section{MATERIAL:}

Table 1: Provenience and element information for Klamath salmonid bones

\begin{tabular}{|c|c|c|c|c|c|}
\hline \begin{tabular}{|l} 
SFU \\
Code
\end{tabular} & Cat No & Site & Provenience & Element & $\begin{array}{l}\text { Weight } \\
\text { (g) }\end{array}$ \\
\hline SBC8 & Beatty-14 & Beatty Curve & N370 E440 WL Lev. 5, QD & Posttemporal & 0.06 \\
\hline SBC9 & Beatty-18 & Beatty Curve & N390 E 458 WH Lev 8, QA & Vertebra fragment & 0.06 \\
\hline SBC10 & Beatty-19 & Beatty Curve & N390 E458 WH Lev 12, QC & Basipterygium & 0.07 \\
\hline SBC11 & Beatty-26 & Beatty Curve & N420 E516 ET Lev 4, QA & Quadrate & 0.21 \\
\hline SBC12 & Beatty-30 & Beatty Curve & N420 E516 ET Lev 4, QA & Coracoid & 0.09 \\
\hline SBC13 & Beatty-41 & Beatty Curve & N420 E516 ET Lev 4, QB & Vertebra type II & 0.33 \\
\hline SBC14 & Beatty-49 & Beatty Curve & N420 E516 ET Lev 3, QD & Vertebra type III & 0.53 \\
\hline SBC15 & Beatty-60 & Beatty Curve & N422 E514 EV Lev 5, QC & Vertebra type II & 0.09 \\
\hline SBC16 & Beatty-67 & Beatty Curve & N422 E516 EW Lev 4, QD & Supracleithrum & 0.17 \\
\hline SBC17 & Beatty-99 & Beatty Curve & N428 E524 EG Lev 3, QA & Vertebra type III & 0.1 \\
\hline SBC18 & Beatty-103 & Beatty Curve & N428 E524 EG Lev 5, QA & Articular & 1.25 \\
\hline SBC19 & Beatty-104 & Beatty Curve & N430 E524 EJ Lev 2, QC & Cleithrum & 0.21 \\
\hline SBC20 & Beatty-107 & Beatty Curve & N430 E524 EJ Lev 8, QC & Vertebra type III & 0.21 \\
\hline SBC21 & BVS-3 & Bezuksewas Village & N191 E98 QA Lev 2 (4W-8) & Cleithrum & 0.18 \\
\hline $\mathrm{SBC} 22$ & BVS-4 & Bezuksewas Village & N191 E98 QA Lev 2 (4W-8) & Urohyal & 0.06 \\
\hline $\mathrm{SBC} 23$ & BVS-11 & Bezuksewas Village & N200 E127 QB Lev 1 (5E-2) & Vertebra type III & 0.17 \\
\hline SBC24 & BVS-13 & Bezuksewas Village & N200 E127 QC Lev 4 (5E-2) & Vertebra type III & 0.08 \\
\hline SBC25 & BVS-15 & Bezuksewas Village & N195 E98 QC Lev 6 (4W-4) & Hypohyal & 0.06 \\
\hline SBC26 & BVS-22 & Bezuksewas Village & N227 E128 QC Lev 5 (3E-1) & Vertebra fragment & 0.15 \\
\hline SBC27 & CSP-1 & Collier State Park & Trench HP\#1 floor fill of house pit & Opercle & 0.23 \\
\hline SBC28 & CSP-2 & Collier State Park & Trench HP\#1 floor fill of house pit & Prootic & 0.06 \\
\hline SBC29 & KSM-4 & Kawumkan Springs Midden & Lev 2 & Vertebra type III & 0.22 \\
\hline $\mathrm{SBC} 30$ & KSM-5 & Kawumkan Springs Midden & Lev 3 & Maxilla & 0.15 \\
\hline SBC31 & KSM-7 & Kawumkan Springs Midden & Lev 4 & Maxilla & 0.22 \\
\hline $\mathrm{SBC} 32$ & KSM-8 & Kawumkan Springs Midden & Lev 4 & Vomer & 0.16 \\
\hline SBC33 & KSM-9 & Kawumkan Springs Midden & Lev 3 & Vertebra type III & 0.5 \\
\hline SBC34 & KSM-10 & Kawumkan Springs Midden & Lev 2 & Vertebra type II & 0.13 \\
\hline SBC35 & KSM-14 & Kawumkan Springs Midden & Lev 2 & Vertebra type II & 0.07 \\
\hline SBC36 & KSM-16 & Kawumkan Springs Midden & Lev 1 & Vertebra type II & 0.53 \\
\hline SBC37 & MRS-1 & Medicine Rock Cave & Unknown & Vertebra type II & 3.27 \\
\hline SBC38 & WRB-1 & Williamson River Bridge & N50 W50 QB Lev 10 & Dentary & 0.36 \\
\hline SBC39 & WRB-3 & Williamson River Bridge & N52 W50 QB Lev 8 & Vertebra type II & 0.07 \\
\hline SBC40 & WRB-6 & Williamson River Bridge & N52 W50 QD Lev 9 & Hyomandibula & 0.38 \\
\hline SBC41 & WRB-12 & Williamson River Bridge & N54 W50 QD Lev 7 & Vertebra type II & 0.44 \\
\hline SBC42 & WRB-14 & Williamson River Bridge & N65 W50 QD Lev 3 & Vertebra type II & 0.49 \\
\hline
\end{tabular}

Ancient DNA Laboratory, Department of Archaeology, Simon Fraser University, Burnaby, BC, Canada www.sfu.ca/ donyang | donyang@sfu.ca| Tel:778-782-4651 | Fax:778-782-5666 


\begin{tabular}{|l|l|l|l|l|l|}
\hline $\begin{array}{l}\text { SFU } \\
\text { Code }\end{array}$ & Cat No & Site & Provenience & Element & $\begin{array}{l}\text { Weight } \\
\text { (g) }\end{array}$ \\
\cline { 1 - 2 } SBC43 & WRB-16 & Williamson River Bridge & N65 W50 QD Lev 11 & Vertebra type III & 0.72 \\
\hline SBC44 & WRB-20 & Williamson River Bridge & N104 W100 QD Lev 6 & Ceratohyal & 0.4 \\
\hline SBC45 & WRB-21 & Williamson River Bridge & N104 W102 QD Lev 4 & Vertebra type III & 0.14 \\
\hline SBC46 & WRB-22 & Williamson River Bridge & N104 W102 QC Lev 4 feat.6 & Vertebra type II & 0.09 \\
\hline SBC47 & WRB-24 & Williamson River Bridge & N104 W102 QD Lev 5 & Vertebra type II & 0.33 \\
\hline SBC48 & WRB-29 & Williamson River Bridge & N130 W100 QD Lev 4 & Vertebra type II & 0.19 \\
\hline SBC49 & WRB-30 & Williamson River Bridge & N130 W100 QB Lev 6 & Vertebra type II & 0.08 \\
\hline SBC50 & Beatty-54 & Beatty Curve & N420 E516 ET Lev 5, QA & Coracoid & 0.15 \\
\hline SBC51 & BVS-14 & Bezuksewas Village & N215 E126 QD Lev 6 (4E-1) & Vertebra type III & 0.09 \\
\hline SBC52 & BVS-17 & Bezuksewas Village & N215 E128 QA Lev 7 (4E-2) & Vertebra type II & 0.08 \\
\hline SBC53 & BVS-20 & Bezuksewas Village & N189 E96 QB Lev 7 (4W-6) & Vertebra type II & 0.13 \\
\hline SBC54 & KSM-13 & Kawumkan Springs Midden & Lev 2 & Vertebra type II & 0.11 \\
\hline SBC55 & KSM-15 & Kawumkan Springs Midden & Lev 1 & Vertebra type II & 0.09 \\
\hline SBC56 & WRB-7 & Williamson River Bridge & N52 W52 QC Lev 4 & Vertebra type II & 0.13 \\
\hline SBC57 & WRB-11 & Williamson River Bridge & N54 W50 QB Lev 5 & Vertebra type II & 0.14 \\
\hline SBC58 & WRB-19 & Williamson River Bridge & N104 W100 QC Lev 5 & Dentary & 0.11 \\
\hline SBC59 & WRB-26 & Williamson River Bridge & N104 W102 QA Lev 7 & Ectopterygoid & 0.12 \\
\hline
\end{tabular}

\section{DNA EXTRACTION:}

Sample preparation and DNA extraction were conducted in the dedicated Ancient DNA laboratory located in the Department of Archaeology at Simon Fraser University. Samples were chemically decontaminated through submersion in commercial bleach (4-6\% sodium hypochlorite) for 10 minutes followed by UV irradiation for $60 \mathrm{~min}$. The samples were incubated overnight in a lysis buffer (0.5 M EDTA pH 8.0; $0.25 \% \mathrm{SDS} ; 0.5 \mathrm{mg} / \mathrm{mL}$ proteinase $\mathrm{K})$ in a rotating hybridization oven at $50^{\circ} \mathrm{C}$. Samples were then centrifuged and 2.5-3.0 $\mathrm{mL}$ of supernatant from each sample was concentrated to $<100 \mu \mathrm{L}$ using Amicon Ultra-4 Centrifugal Filter Devices (10 KD, 4mL, Millipore). Concentrated extracts were purified using QIAquick spin columns (QIAGEN, Hilden, Germany) based on the method developed by Yang et al. (2004; 1998); $100 \mu \mathrm{L}$ of DNA from each sample was eluted from QIAquick column for PCR amplification. 


\section{PCR SETUP}

PCR amplifications were performed on an Eppendorf ${ }^{\mathrm{TM}}$ Mastercycler Personal Thermocycler using a $30 \mu \mathrm{L}$ reaction volume containing 1.5X Applied Biosystems ${ }^{\mathrm{TM}}$ Buffer, $2 \mathrm{mM} \mathrm{MgCl} 20.2$ $\mathrm{mM}$ dNTP, $1.0 \mathrm{mg} / \mathrm{mL}$ BSA, 0.1-0.6mM primer, 3.0 $\mu \mathrm{L}$ DNA sample and $2.5 \mathrm{U}$ AmpliTaq Gold (Applied Biosystems). Salmonid d-loop fragments (249bp) and cytochrome b (cytb) fragments (168bp) were either co-amplified in a single multiplex reaction, or amplified in separate PCR reactions using previous published protocols (Yang and Speller 2006). Samples that failed to amplify using both the cytb and longer d-loop primer sets were also amplified with primers targeting a short 135bp d-loop fragment (SMC3/4) which is sufficient for differentiating Oncorhynchus species (Primers SMC3/SMC4 in Yang et al. 2004). Five uL of PCR product from each sample were separated on a $2 \%$ agarose gel, and visualized using SYBR Green ${ }^{\mathrm{TM}}$ (Clare Chemical Research Co.USA), on dark reader.

Mitochondrial DNA was successfully amplified from 45 of 52 samples, a success rate of $86 \%$. Samples recovered from Beatty Curve, Bezuksewas Village, Kawumkan Springs Midden and Williamson River Bridge all yielded mtDNA, while the two samples from Collier State Park (SBC27 \& 28) and the sample from Medicine Rock Cave (SBC37) did not yield any amplification results. At least two mtDNA fragments were amplified from 43 samples (i.e. the cytb, d-loop and/or SMC3/4 fragments), while two samples yielded only the cytochrome b fragment (SBC 25 and SBC29). Despite repeat amplification with the short SMC3/4 primer set, especially designed for degraded salmonid DNA, seven samples failed to yield any mtDNA amplification. Repeat PCR amplifications and sequencing were conducted for five successful samples (SBC 36, 41, 48, and 59) as a reproducibility test.

\section{SEQUENCING}

Successfully amplified samples were purified using an ExoSAP-IT protocol (USB Corporation) or a QIAquick purification method (QIAGEN, Hilden, Germany), and sent to the Operon, Ltd. facility for sequencing. Cytochrome $b$ fragments were sequenced using the forward primer and the d-loop fragments were sequenced using a modified reverse sequencing primer. The SMC3/4 fragment was sequenced from both directions. Good quality sequences were obtained for all but 
one of the amplified samples: SBC25 yielded a poor quality d-loop sequence, however, the cytochrome b sequences was sufficient to make a species identification for this sample.

The obtained sequences were compared to Genbank reference sequences through the BLAST application to determine their closest match, and to ensure that they did not match with any other unexpected species or sequences. Sample sequences were visually edited and base pair ambiguities were examined using ChromasPro software (www.technelysium.com.au). Multiple alignments of the ancient sequences and published salmonid reference sequences were conduced using ClustalW (Thompson et al. 1994), through BioEdit (Hall 1999), and phylogenetic analysis was conducted using Mega 4.0 software (Tamura et al. 2007).

Appendix 1, 2 \& 3 display multiple alignments of the ancient salmonid d-loop, cytochrome b and SMC3/4 fragments, respectively, and reference sequences obtained from Genbank. Appendix 3 $\& 4$ are neighbour-joining trees displaying the phylogenetic relationship between the obtained dloop and cytb haplotypes, respectively, and reference sequences obtained from Genbank.

\section{SPECIES IDENTIFICATION}

According to lab protocols, a species identification is assigned to a sample only if it matches identically or very closely with published reference sequences, and if no other evidence, including reproducibility tests or additional sequencing of the same sample indicated a different species.

All PCR reactions yielded salmonid sequences which matched either identically, or within a few base pairs, with Genbank reference sequences for O. mykiss and O. tshawytscha. Table 2 presents the species identifications for the 45 successful samples; 37 samples were identified as O. mykiss (Rainbow trout) and eight as O. tshawytscha (Chinook salmon). Species identities obtained through the amplification and sequencing of different mtDNA fragments (i.e. cytb and d-loop), matched in all cases, supporting the authenticity of the identifications.

6 Ancient DNA Laboratory, Department of Archaeology, Simon Fraser University, Burnaby, BC, Canada www.sfu.ca/ donyang | donyang@sfu.ca | Tel:778-782-4651 | Fax:778-782-5666 
Table 2: Species identifications for Klamath salmonid remains

\begin{tabular}{|c|c|c|c|c|c|}
\hline $\begin{array}{l}\text { SFU } \\
\text { Code }\end{array}$ & CatNo & $\begin{array}{c}\text { Cytochrome b } \\
\text { ID }\end{array}$ & D-loop ID & D-loop haplotype & SMC3/4 ID \\
\hline SBC8 & Beatty-14 & O. mykiss & O. mykiss & ST1 & \\
\hline SBC9 & Beatty-18 & O. mykiss & O. mykiss & ST1 & \\
\hline SBC10 & Beatty-19 & O. mykiss & O. mykiss & ST2 & \\
\hline SBC11 & Beatty-26 & O. mykiss & O. mykiss & ST2 & \\
\hline SBC12 & Beatty-30 & O. mykiss & O. mykiss & ST2 & \\
\hline SBC13 & Beatty-41 & O. tshawytscha & O. tshawytscha & - & \\
\hline SBC14 & Beatty-49 & O. tshawytscha & O. tshawytscha & - & \\
\hline SBC15 & Beatty-60 & O. mykiss & O. mykiss & ST2 & \\
\hline SBC16 & Beatty-67 & O. mykiss & O. mykiss & ST2 & \\
\hline SBC17 & Beatty-99 & O. mykiss & O. mykiss & ST2 & \\
\hline SBC18 & Beatty-103 & O. mykiss & O. mykiss & ST1 & \\
\hline SBC19 & Beatty-104 & O. mykiss & O. mykiss & ST2 & \\
\hline SBC20 & Beatty-107 & O. mykiss & O. mykiss & ST2 & \\
\hline SBC21 & BVS-3 & O. mykiss & O. mykiss & ST1 & \\
\hline SBC22 & BVS-4 & O. mykiss & O. mykiss & ST2 & \\
\hline SBC23 & BVS-11 & O. mykiss & O. mykiss & ST2 & \\
\hline SBC24 & BVS-13 & O. mykiss & O. mykiss & ST2 & \\
\hline SBC25 & BVS-15 & O. mykiss & Poor sequencing quality & No Hap ID & \\
\hline SBC26 & BVS-22 & O. tshawytscha & O. tshawytscha & & \\
\hline SBC27 & CSP-1 & NA & NA & & NA \\
\hline SBC28 & CSP-2 & NA & NA & & NA \\
\hline SBC29 & KSM-4 & O. mykiss & NA & No Hap ID & \\
\hline SBC30 & KSM-5 & O. mykiss & O. mykiss & ST2 & \\
\hline SBC31 & KSM-7 & O. mykiss & O. mykiss & ST2 & \\
\hline SBC32 & KSM-8 & O. mykiss & O. mykiss & ST2 & \\
\hline SBC33 & KSM-9 & NA & O. tshawytscha & & O. tshawytscha \\
\hline SBC34 & KSM-10 & NA & NA & & NA \\
\hline SBC35 & KSM-14 & O. mykiss & O. mykiss & ST1 & \\
\hline SBC36 & KSM-16 & O. tshawytscha* & O. tshawytscha & & \\
\hline SBC37 & MRS-1 & NA & NA & & NA \\
\hline SBC38 & WRB-1 & O. mykiss & O. mykiss & ST2 & \\
\hline SBC39 & WRB-3 & O. mykiss & O. mykiss & ST2 & O. mykiss \\
\hline SBC40 & WRB-6 & O. mykiss & O. mykiss & ST2 & \\
\hline SBC41 & WRB-12 & O. mykiss* & O. mykiss* & ST2 & \\
\hline SBC42 & WRB-14 & O. tshawytscha & O. tshawytscha & & \\
\hline SBC43 & WRB-16 & O. tshawytscha & O. tshawytscha & & \\
\hline SBC44 & WRB-20 & O. mykiss & O. mykiss & ST1 & \\
\hline SBC45 & WRB-21 & O. mykiss & O. mykiss & No Hap ID & \\
\hline SBC46 & WRB-22 & NA & NA & & NA \\
\hline SBC47 & WRB-24 & O. mykiss & O. mykiss & ST2 & \\
\hline SBC48 & WRB-29 & O. mykiss * & O. mykiss & ST2 & \\
\hline SBC49 & WRB-30 & O. mykiss & O. mykiss & ST1 & \\
\hline
\end{tabular}

Ancient DNA Laboratory, Department of Archaeology, Simon Fraser University, Burnaby, BC, Canada www.sfu.ca/ donyang | donyang@sfu.ca | Tel:778-782-4651 | Fax:778-782-5666 


\begin{tabular}{|l|l|l|l|l|l|} 
SBC50 & Beatty-54 & O. mykiss & O. mykiss & ST2 & \\
\hline SBC51 & BVS-14 & O. mykiss & O. mykiss & ST2 & \\
\hline SBC52 & BVS-17 & NA & NA & & NA \\
\hline SBC53 & BVS-20 & O. tshawytscha & O. tshawytscha & & \\
\hline SBC54 & KSM-13 & O. mykiss * & O. mykiss * & ST1 & \\
\hline SBC55 & KSM-15 & O. mykiss & O. mykiss & ST1 & \\
\hline SBC56 & WRB-7 & O. mykiss & O. mykiss & ST1 & \\
\hline SBC57 & WRB-11 & NA & NA & & NA \\
\hline SBC58 & WRB-19 & O. mykiss & O. mykiss & ST1 & \\
\hline SBC59 & WRB-26 & O. mykiss * & O. mykiss & ST2 & O. mykiss \\
\hline
\end{tabular}

Note: * indicated that PCR and sequencing were repeated. NA= No amplification

All eight samples identified as $O$. tshawytscha, displayed identical cytochrome b and d-loop haplotypes, respectively. All 37 samples identified as O. mykiss displayed identical cytochrome b haplotypes, though two different d-loop haplotypes were identified (haplotypes ST1 and ST2). D-loop haplotypes were identified for 34 of the 37 O. mykiss samples. Three O. mykiss samples did not yield adequate DNA for a d-loop haplotype identification: O. mykiss samples SBC29 failed to amplify the long d-loop fragment, while the d-loop fragments obtained for SBC25 and SBC45 were not sufficiently clear to make a haplotype identification.

The two O. mykiss haplotypes (ST1 and ST2) differ at four different base pair positions, but are consistent with the range of variation present in modern populations of North American Rainbow Trout populations (Bagley and Gall 1998). O. mykiss haplotype ST1 was identified in 11 archaeological salmonid samples, including those recovered from Beatty Curve, Bezuksewas Village, Kawumkan Springs Midden, and Williamson River Bridge. Haplotype ST1 has also been identified in a modern coastal rainbow trout (O. mykiss) individual collected from Skookumchuck River, Washington (Genbank accession DQ288271 Brown et al. 2006), as well as coastal steelhead populations from Mad River Hatchery, CA and Coralitos Creek CA (Haplotypes RTDL06, RTDR07, Bagley and Gall 1998).

O. mykiss haplotype ST2 was identified in 23 of the archaeological remains, including those from Beatty Curve, Bezuksewas Village, Kawumkan Springs Midden, and Williamson River Bridge. This haplotype has also been observed in individuals from an inland rainbow trout population at Eagle Lake Hatchery, CA (Haplotype RTDL32 in Bagley and Gall 1998). 
The relationship of these $O$. mykiss haplotypes to Klamath river anadromous Steelhead and inland Rainbow Trout cannot be assessed based on the present data. Though recent studies have examined the genetic variability of Klamath basin trout populations through enzyme encoding loci (Currens et al. 2009) and microsatellite loci (Pearse et al. Submitted), comparable mitochondrial DNA sequences for these populations are not yet available. Due to a lack of comparative modern data, the ancient mtDNA analysis cannot definitely identify these archaeological salmon remains as either Steelhead or Rainbow Trout.

\section{AUTHENTICATION}

The dedicated ancient DNA laboratory at SFU follows strict contamination control protocols such as: the separation of the pre-PCR and post-PCR work spaces; the use of ancient DNA dedicated equipment including clothing, equipment and reagents; the analysis of both positive and negative controls along side the ancient DNA samples; and multiple extractions from the same sample in order to reproduce the original results. Ancient DNA amplicons and sequences are scrutinized to ensure that they follow expected amplification and phylogenetic patterns (Poinar 2003).

The results of the DNA amplification and sequences suggest that the recovered salmonid DNA is authentic. The contamination controls undertaken in this study were successful at eliminating any systematic contamination as no PCR amplification was observed blank extracts and PCR negative controls. D-loop and cytb sequences from all samples yielded the same species identities, suggesting that there was no cross-contamination between samples. Repeat amplification and sequencing for five samples yielded consistent results in all cases.

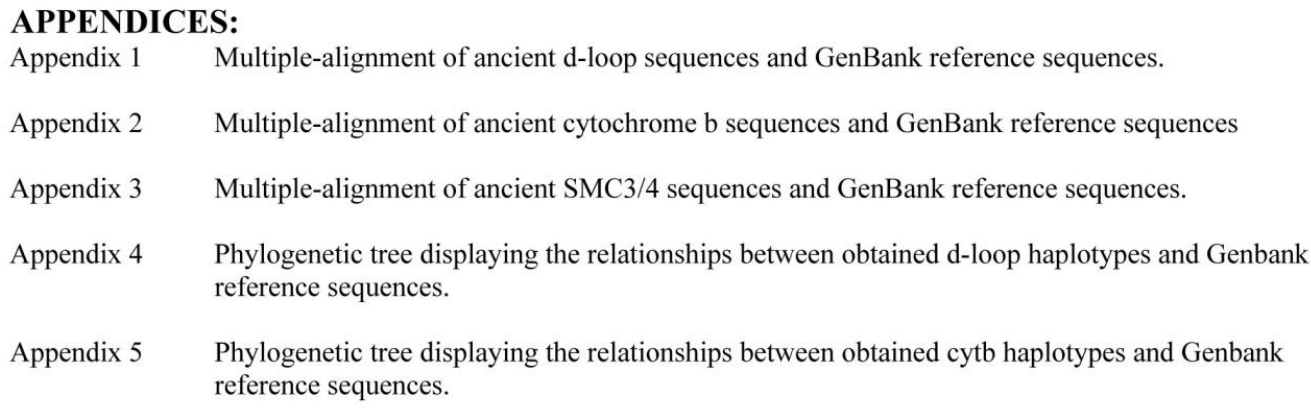

9 Ancient DNA Laboratory, Department of Archaeology, Simon Fraser University, Burnaby, BC, Canada www.sfu.ca/ donyang | donyang@sfu.ca | Tel:778-782-4651 | Fax:778-782-5666 


\section{REFERENCES:}

Bagley, M. J. and G. A. E. Gall

1998 Mitochondrial and nuclear DNA sequence variability among populations of rainbow trout (Onchorhynchus mykiss). Molecular Ecology 7(8):945-961.

Brown, K. H., R. E. Drew, L. A. Weber and G. H. Thorgaard 2006 Intraspecific variation in the rainbow trout mitochondrial DNA genome. Comparative Biochemistry and Physiology Part D: Genomics and Proteomics 1(2):219-226.

Currens, K. P., C. B. Schreck and H. W. Li

2009 Evolutionary Ecology of Redband Trout. Transactions of the American Fisheries Society 138:797-817.

Hall, T. A.

1999 BioEdit: a user-friendly biological sequence alignment editor and analysis program for Windows 95/98/NT. Nucl. Acids. Symp. Ser. 41:95-98.

Pearse, D. E., S. L. Gunckel and S. E. Jacobs Submitted Population structure and genetic divergence of rainbow and redband trout (Oncorhynchus mykiss) in the upper Klamath Basin.

Poinar, H. N.

2003 The top 10 list: criteria of authenticity for DNA from ancient and forensic samples. International Congress Series 1239:575-579.

Shedlock, A. M., J. D. Parker, D. A. Crispin, T. W. Pietsch and G. C. Burner 1992 Evolution of the salmonid mitochondrial control region. Molecular Phylogenetics and Evolution 1:179-192.

Tamura, K., J. Dudley, M. Nei and S. Kumar 2007 MEGA4: Molecular Evolutionary Genetics Analysis (MEGA) software version 4.0. Molecular Biology and Evolution 24:1596-1599.

Thompson, J. D., D. G. Higgins and T. J. Gibson 1994 CLUSTAL W: improving the sensitivity of progressive multiples sequence alignments through sequence weighting, position-specific gap penalties and weight matrix choice. Nucleic Acids Research 22:4673-4680.

Yang, D. Y., A. Cannon and S. R. Saunders 2004 DNA species identification of archaeological salmon bone from the Pacific Northwest Coast of North America. Journal of Archaeological Science 31(5):619-631.

Yang, D. Y., B. Eng, J. S. Waye, J. C. Dudar and S. R. Saunders 1998 Improved DNA extraction from ancient bones using silica-based spin columns. American Journal of Physical Anthropology 105:539-543.

Yang, D. Y. and C. F. Speller 2006 Co-amplification of cytochrome $b$ and D-loop mtDNA fragments for the identification of degraded DNA samples. Molecular Ecology Notes 6(3):605-608.

10 Ancient DNA Laboratory, Department of Archaeology, Simon Fraser University, Burnaby, BC, Canada www.sfu.ca/ donyang | donyang@sfu.ca | Tel:778-782-4651 | Fax:778-782-5666 


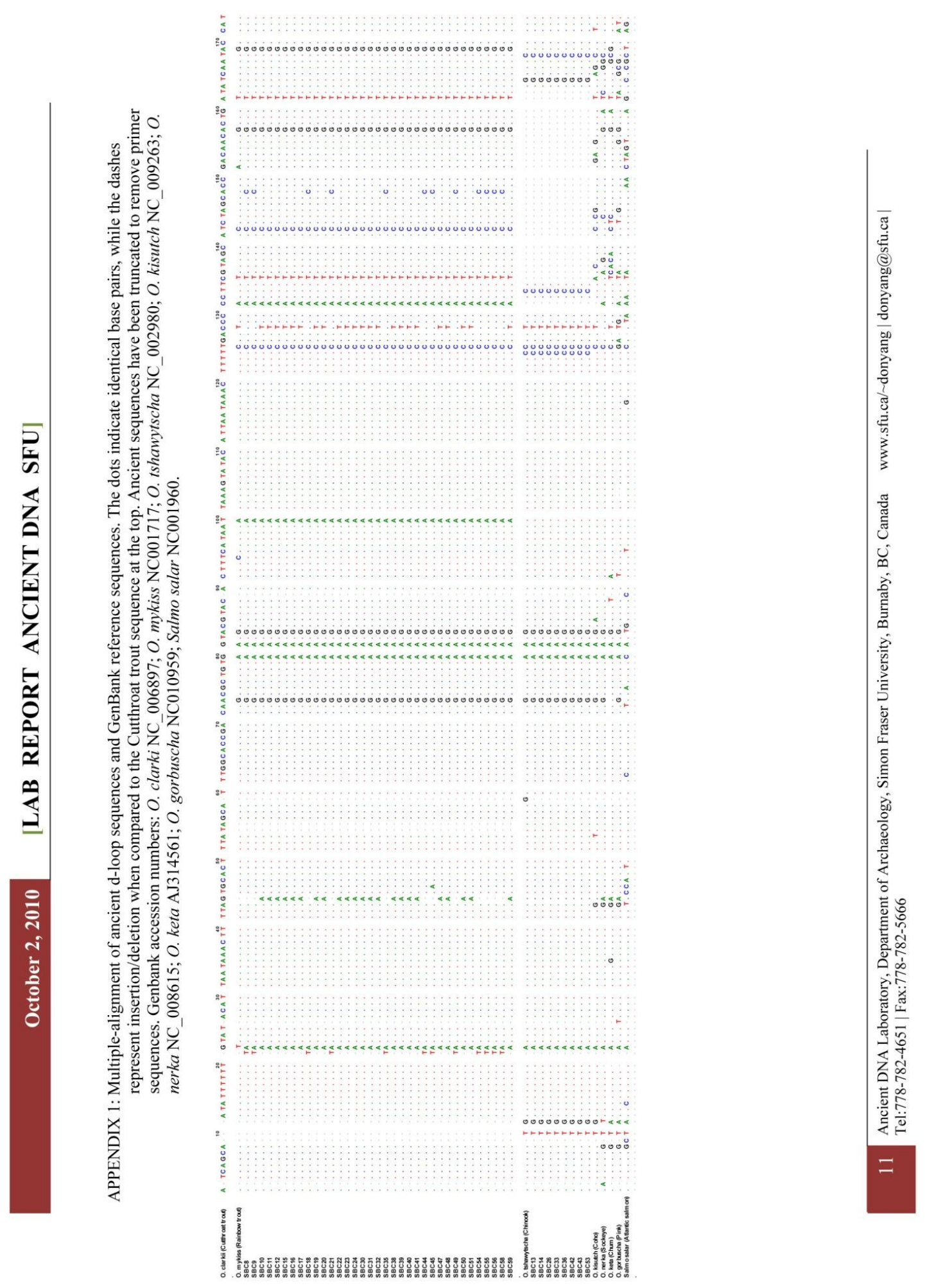




\section{October 2, $2010 \quad$ [LAB REPORT ANCIENT DNA SFU $]$}

APPENDIX 2: Multiple-alignment of ancient cytochrome b sequences and GenBank reference sequences. The dots indicate identical base pairs, while the dashes represent insertion/deletion when compared to the Cutthroat trout sequence at the top. Ancient sequences have been truncated to remove primer sequences. Genbank accession numbers: Genbank accession numbers: $O$. clarki NC 006897; $O$. mykiss NC001717; O. tshawytscha NC_002980; O. kisutch NC_009263; O. nerka NC_008615; $O$ keta AJ314561; O. gorbuscha NC010959; Salvelinus malma DQ298801; Salmo salar NC001960.

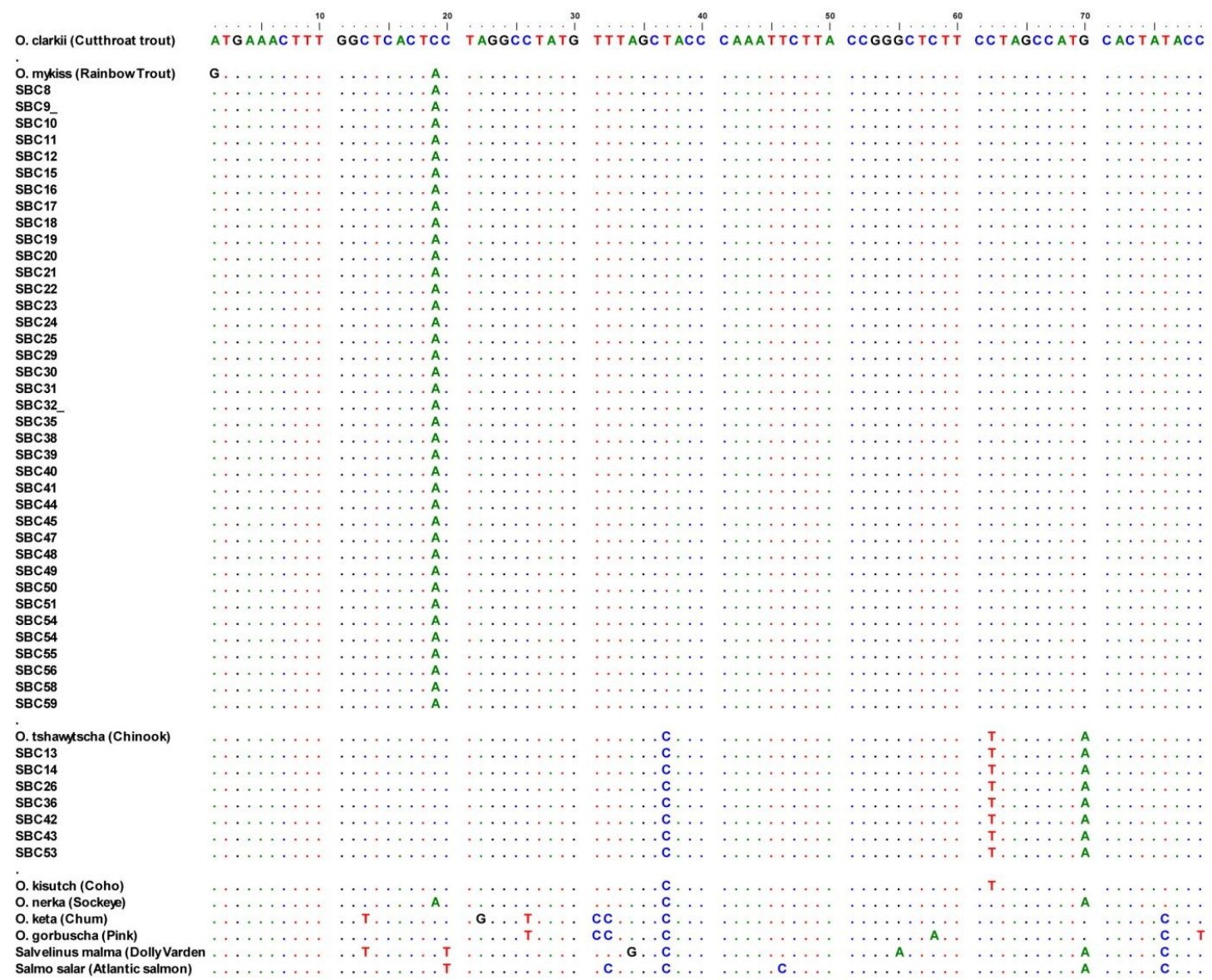

12 Ancient DNA Laboratory, Department of Archaeology, Simon Fraser University, Burnaby, BC, Canada www.sfu.ca/ donyang | donyang@sfu.ca | Tel:778-782-4651 | Fax:778-782-5666 

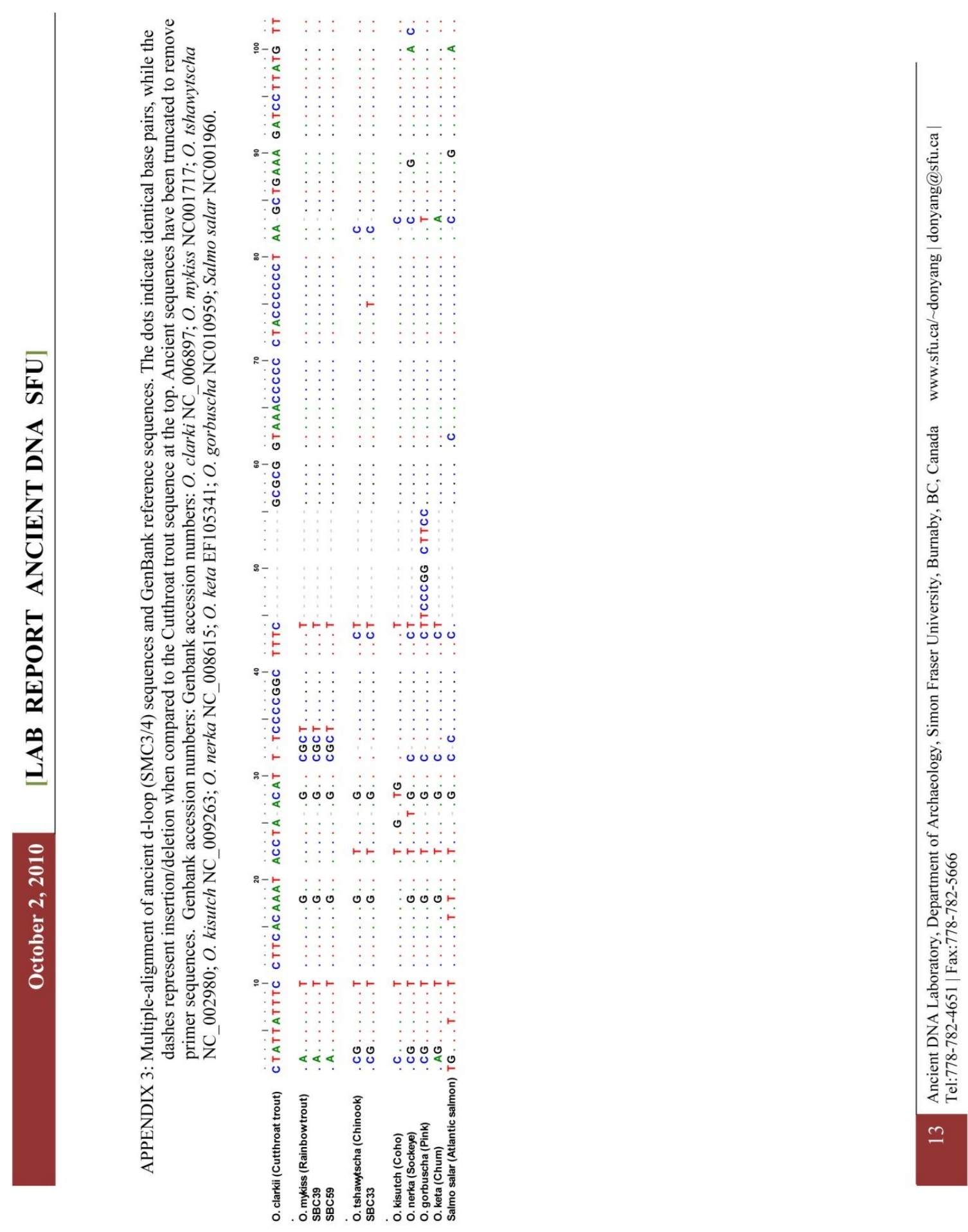


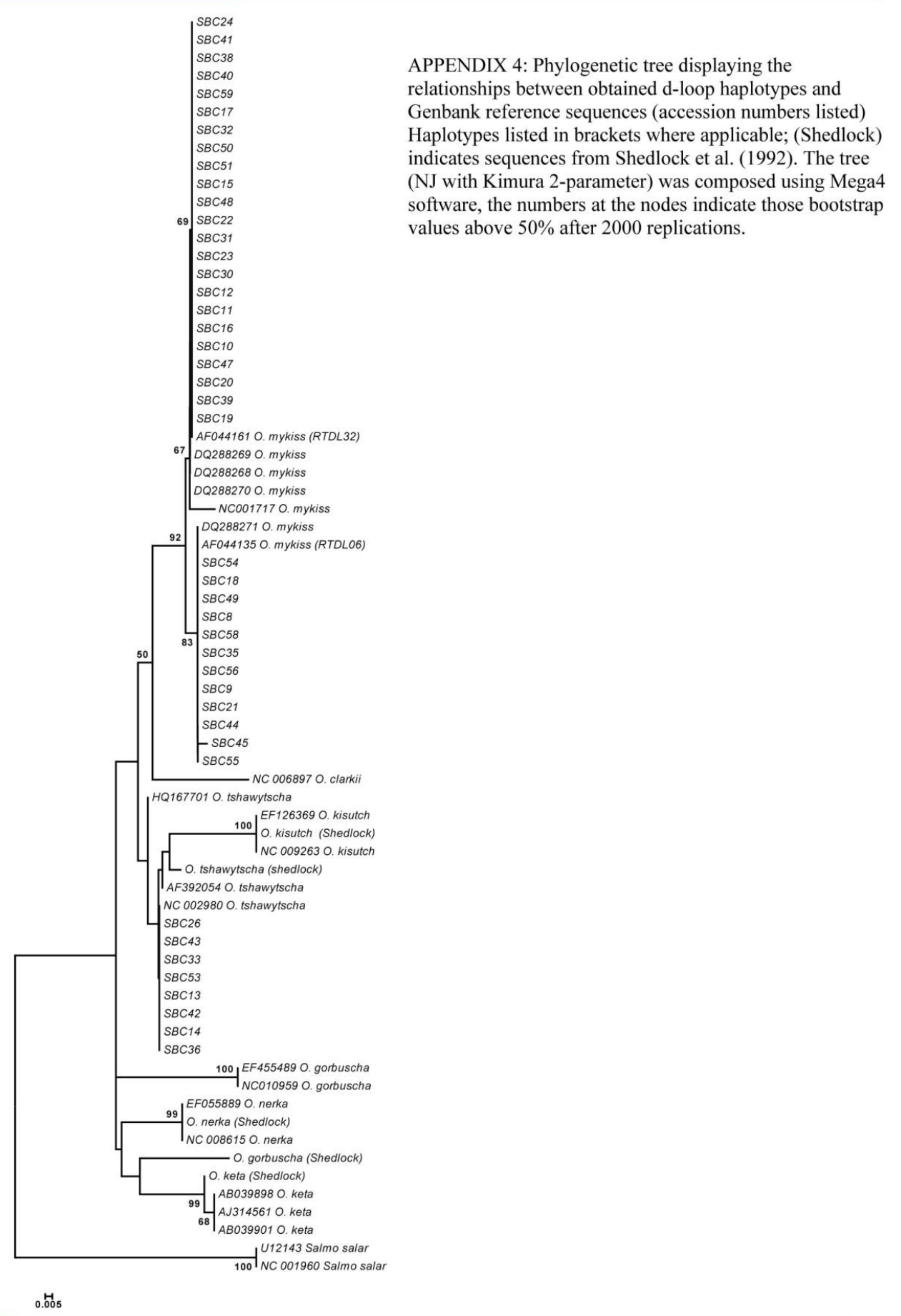

14 Ancient DNA Laboratory, Department of Archaeology, Simon Fraser University, Burnaby, BC, Canada www.sfu.ca/ donyang | donyang@sfu.ca | Tel:778-782-4651 | Fax:778-782-5666 


\section{October 2, 2010 [LAB REPORT ANCIENT DNA SFU]}

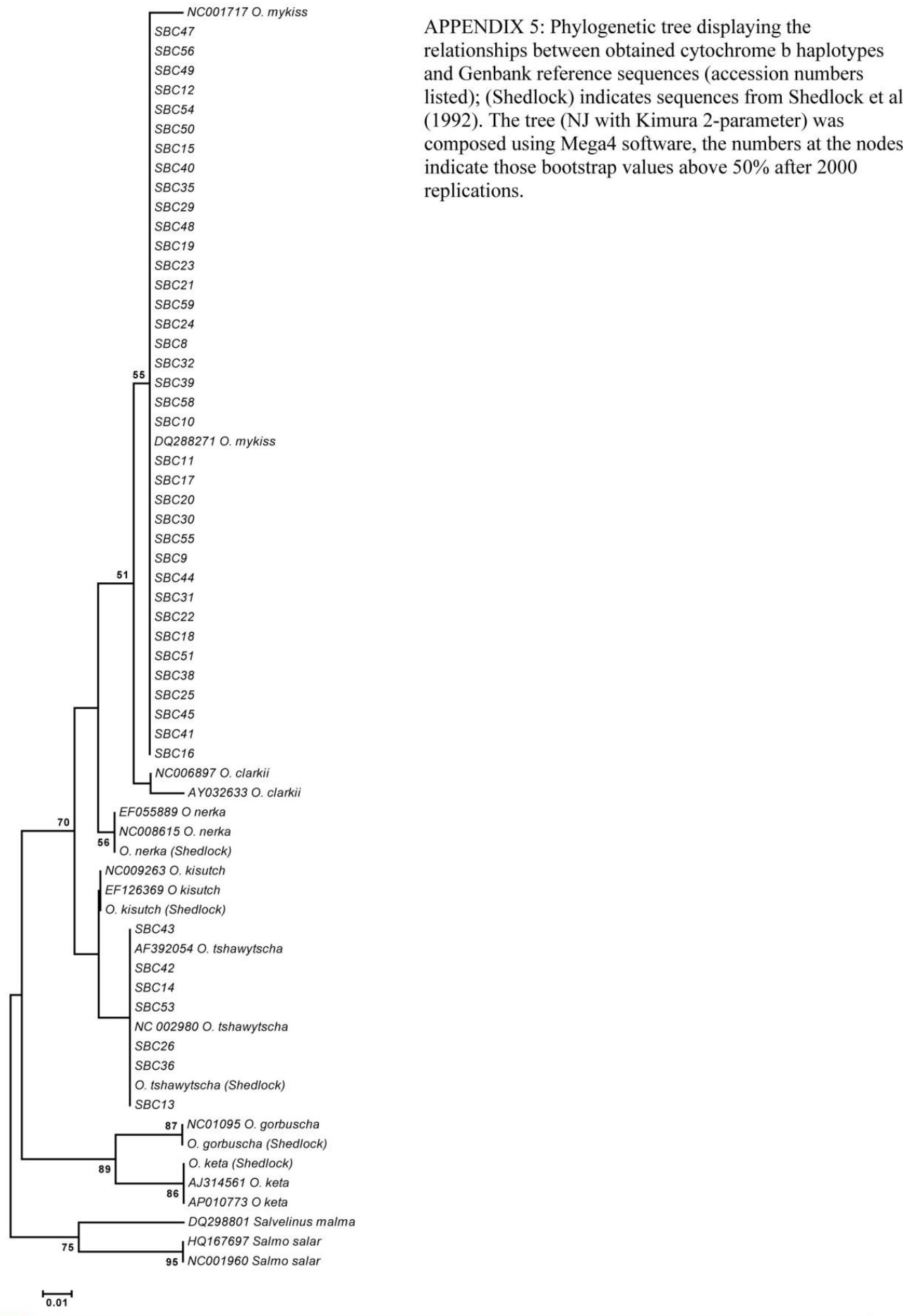

15 Ancient DNA Laboratory, Department of Archaeology, Simon Fraser University, Burnaby, BC, Canada www.sfu.ca/ donyang | donyang@sfu.ca | Tel:778-782-4651 | Fax:778-782-5666 


\section{Appendix C: Radiocarbon Lab Data and Dates}




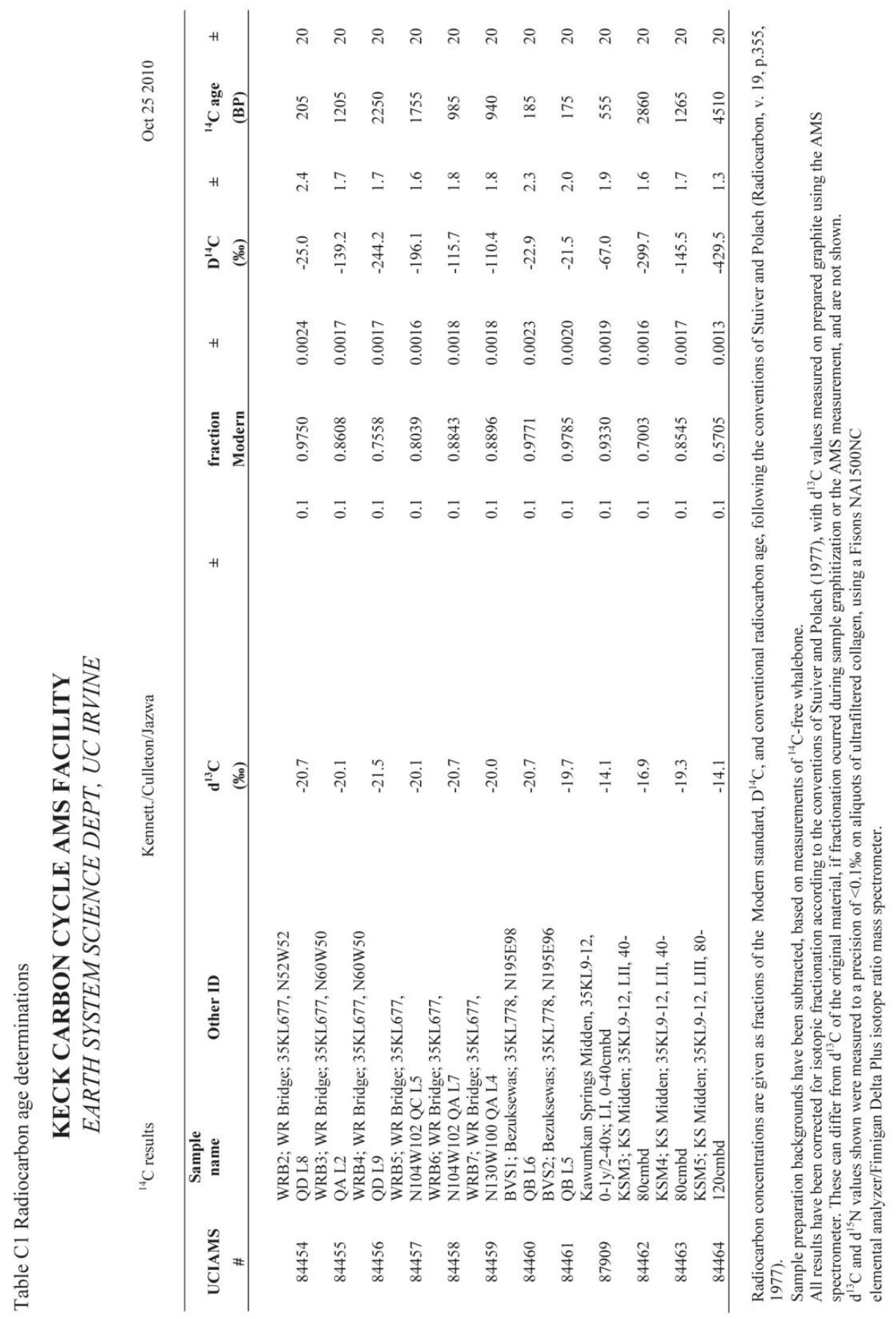




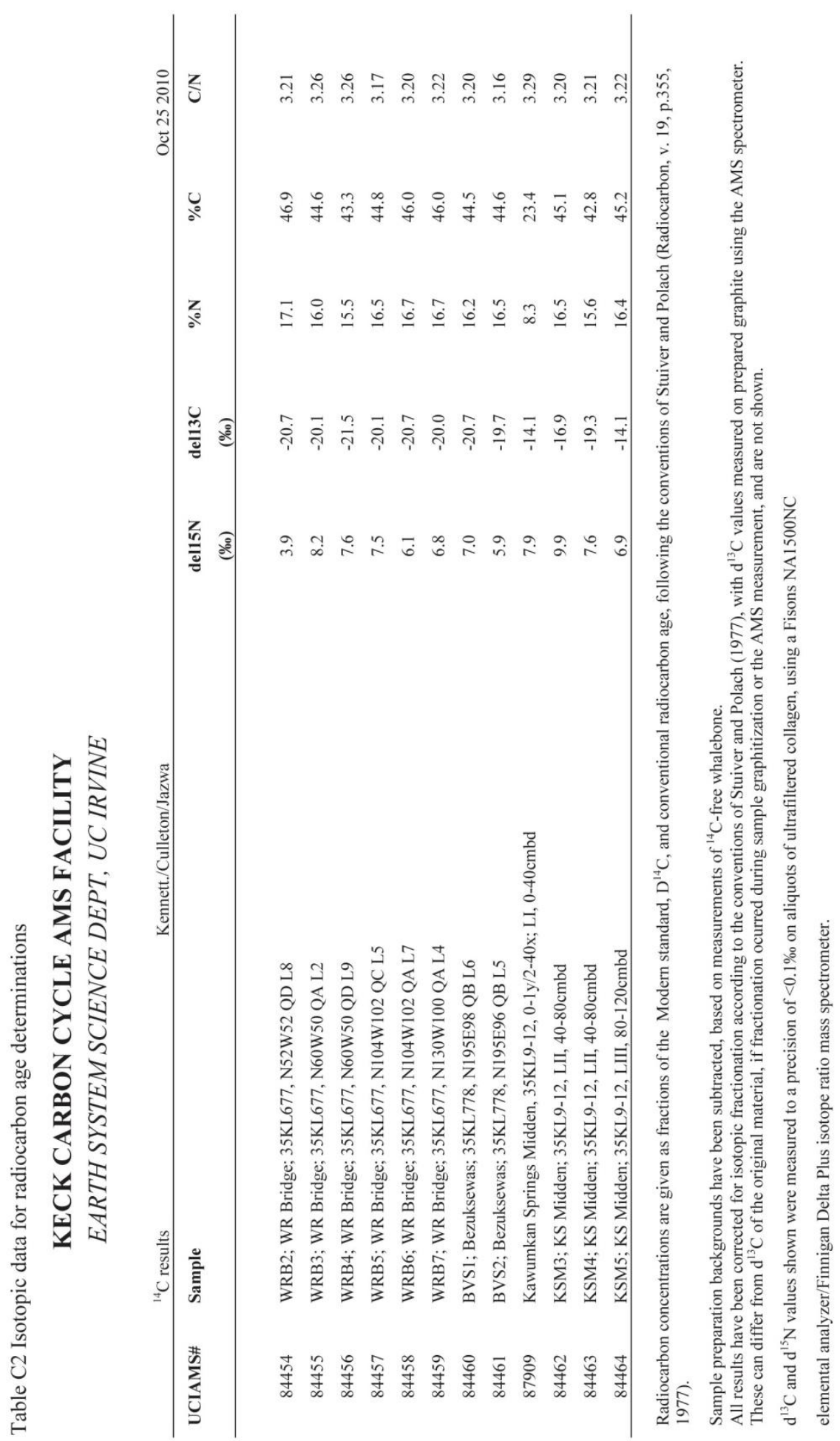




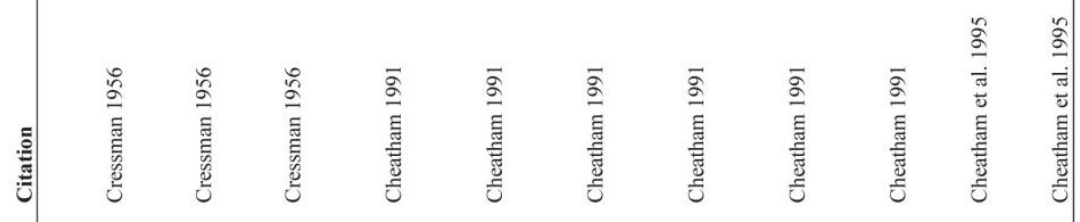

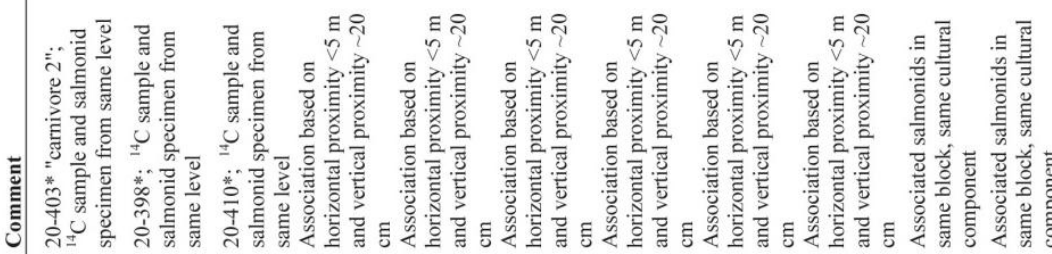

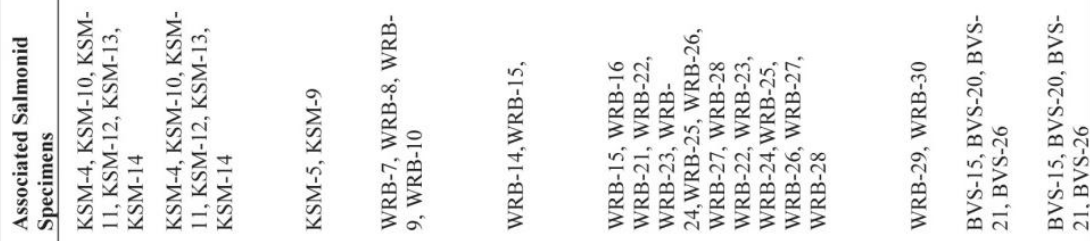

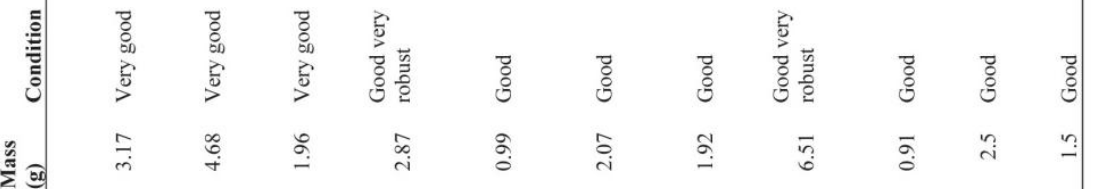

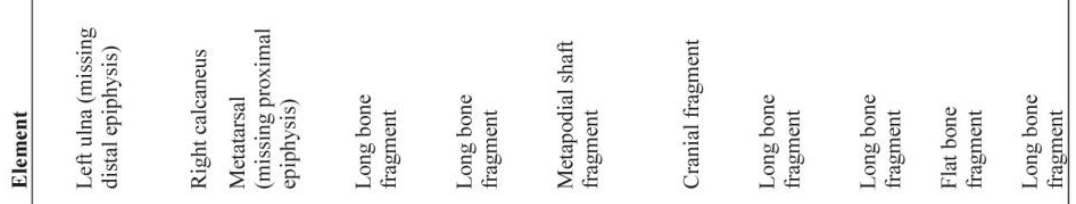

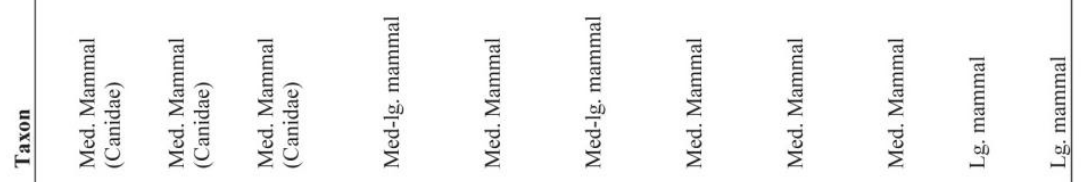

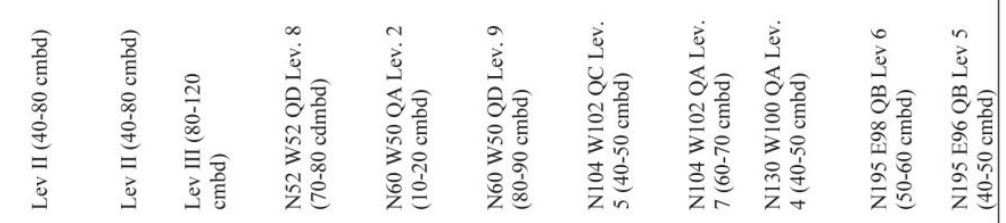

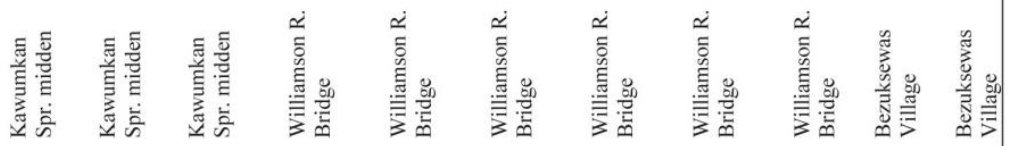

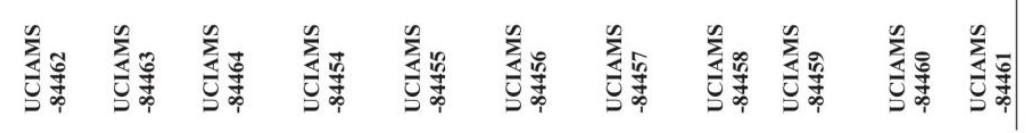

